\title{
GEOTHERMAL EXPLORATION ASSESSMENT AND INTERPRETATION, KLAMATH BASIN, OREGON - \\ SWAN LAKE AND KLAMATH HILLS AREA
}

M. Stark, N. Goldstein, H. Wollenberg

B. Strisower, H. Hege and M. Wilt

May 1979

Prepared for the U.S. Department of Energy under Contract $\mathrm{W}-7405-\mathrm{ENG}-48$

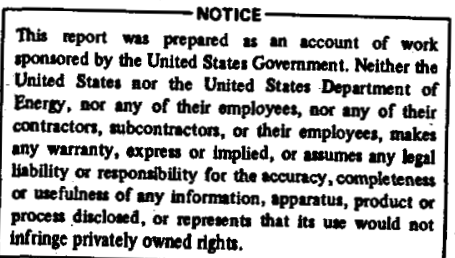

This report was prepared as an account of work sponsored by the United States Government. Neither the Enersy, mor any of theit amploynes nepartment of

contractors, subcontractors, of their employees, makes

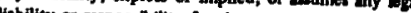

infringe privately owned tight 


\section{DISCLAIMER}

This report was prepared as an account of work sponsored by an agency of the United States Government. Neither the United States Government nor any agency Thereof, nor any of their employees, makes any warranty, express or implied, or assumes any legal liability or responsibility for the accuracy, completeness, or usefulness of any information, apparatus, product, or process disclosed, or represents that its use would not infringe privately owned rights. Reference herein to any specific commercial product, process, or service by trade name, trademark, manufacturer, or otherwise does not necessarily constitute or imply its endorsement, recommendation, or favoring by the United States Government or any agency thereof. The views and opinions of authors expressed herein do not necessarily state or reflect those of the United States Government or any agency thereof. 


\section{DISCLAIMER}

Portions of this document may be illegible in electronic image products. Images are produced from the best available original document. 


\section{ACKNOWLEDGEMENTS}

We wish to thank first of all the representatives of companies and institutions who contributed their data to this study. These individuals comprise the Klamath Basin Geothermal Assessment Steering Committee, and their cooperation and advice has proven invaluable.

Richard G. Bowen and Joseph Riccio, representing the oregon Department of Geology and Mineral Industries (DOGAMI) deserve special appreciation for their informative, good-natured tour of parts of the Basin. We also thank the staff at the Geo-Heat Utilization Center at oregon Institute of Technology for showing us their impressive heating system.

Keeva Vozoff shared his years of experience in magnetotellurics with us; his advice and his access to some amazing computer programs were extremely helpful in interpretation.

We also thank Ed Sammel of the U.S. Geological survey for his advice and his continuing interest in the project.

Finally, we appreciate the efforts of Orah Goldman and Mildred Bowman for typing the many iterations leading up to the final manuscript, John Vargas and Miriam Schwartz, the illustrators, Barbara srulovitz, the report coordinator, and the staff of the Technical Information Division at Lawrence Berkeley Laboratory. 
A synthesis and preliminary interpretation of predominantly geophysical information relating to the Klamath Basin geothermal resource is presented. The Swan Lake Valley area, northeast of klamath Falls, and the Klamath Hills area, south of Klamath Falls, are discussed in detail. Available geophysical data, including gravity, magnetic, electrical resistivity, microearthquake, roving dipole resistivity, audio-magnetotelluric (AMT) and magnetotelluric (MT) data sets, are examined and reinterpreted for these areas. One- and two-dimensional modeling techniques are applied, and general agreement among overlapping data sets is achieved. The MT method appears well suited to this type of exploration, although interpretation is difficult in the complex geology. Roving dipole and AMT are useful in reconnaissance, while gravity and magnetics help in defining structure. For the Swan Lake Valley the data suggest buried electrically conductive zones beneath Meadow Lake Valley and Swan Lake, connected by a conductive layer at 1 kilometer depth. In the klamath Hills area, the data suggest a conductive zone centered near the northwestern tip of stukel Mountain, associated with a concealed northeast-trending cross-fault. Another conductive zone appears near some producing hot wells at the southwestern edge of the Klamath Hills. These conductive zones may represent geothermal reservoirs. Follow-up work is recommended for each target area. 
( 
vii

TABLE OF CONTENTS

$\underline{\text { Page }}$

LIST OF FIGURES

ix

I INTRODUCTION

II REGIONAL GEOLOGY AND GEOPHYSICS

Geology

Geophysics

III SWAN LAKE VALLEY AREA. 11

Topography and General Geology 11

Gravity Survey $\quad 14$

Aeromagnetic Survey 1.7

Roving Dipole, Electromagnetic and Direct Current 17

$\begin{array}{ll}\text { Resistivity Sounding Surveys } & 17 \\ & 26\end{array}$

Magnetotelluric Survey Interpretation $\quad 36$

$\begin{array}{ll}\text { Synthesis and Geologic Interpretation } & 36 \\ \text { The Geothermal Target } & 38\end{array}$

IV KLAMATH HILLS AREA

Topography and General Geology $\quad 39$

Gravity Survey $\quad 42$

Microearthquake Survey $\quad \cdot 42$

Audio-Magnetotelluric Survey 44

Roving Dipole Resistivity Survey $\quad 46$

Direct Current and Electromagnetic soundings 56

Synthesis and Geological Interpretation 56

Geothermal Targets 58

V EVALUATION OF GEOPHYSICAL METHODS $\quad 59$

VI CONCLUSIONS $\quad 61$

REFERENCES $\quad \because \quad 64$

APPENDIX: KLAMATH BASIN GEOTHERMAL RESOUURES BIBLIOGRAPHY 66 
LIST OF FIGURES

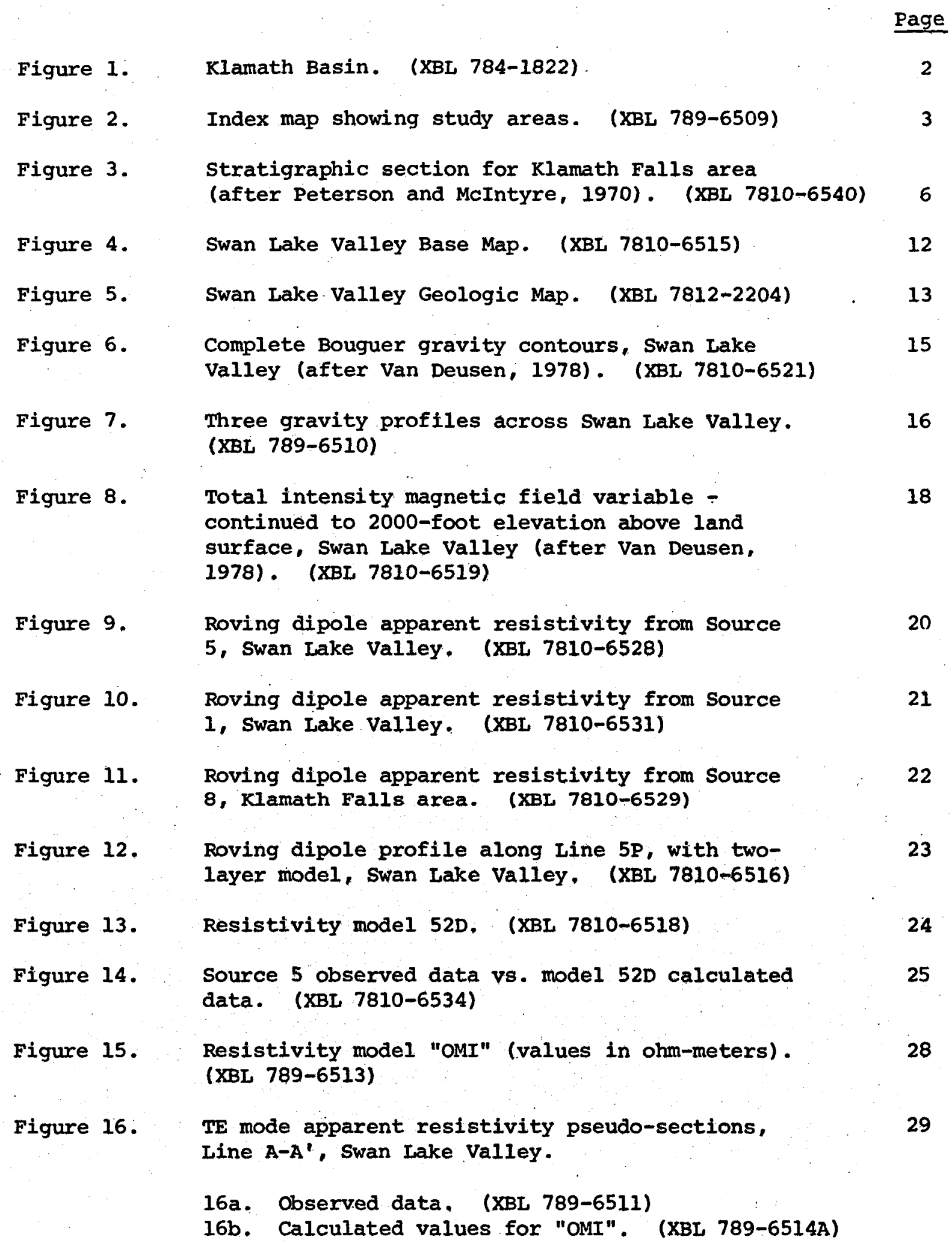


( 
Figure 17. TM mode apparent resistivity pseudo-sections,

Line $A-A^{\prime}$, Swan Lake Valley.

17a. Observed data. (XBL 789-6512)

17b. Calculated data for model "OMI". (XBL 7810-2090A)

Figure 18. Resistivity model "SMI" (values in ohm-meters).

(XBL 789-2096)

Figure 19. TE mode apparent resistivity pseudo-sections,

Line A-A', Swan Lake Valley.

19a. Observed data, modes switched at stations

4, 8A and 8B. (XBL 789-2085)

19b. Calculated values for model "SMI".

(XBL 7810-2089A)

Figure 20. TM mode apparent resistivity pseudo-sections,

Line A-A', Swan Lake Valley.

20a. Observed data, modes switched at stations

$4,8 \mathrm{~A}$ and $8 \mathrm{~B}$. (XBL 7810-2087)

20b. Calculated values for model "SMI".

(XBL 7810-2091A)

Figure 21. Resistivity model "ISMID" (values in ohm-meters). (XBL 789-2095)

Figure 22. Apparent resistivity pseudo-sections calculated for model ISMID, Line A-A', Swan lake Valley.

22a. TE mode. (XBL 7810-2088)

22b. TM mode. (XBL 789-2086A)

Figure 23. Klamath Hills area base map. (XBL 7810-6517) 40

Figure 24. Klamath Hills area geologic map. (XBL 7812-2203A) 41

Figure 25. Complete Bouguer gravity map, Klamath Hills area 43

(after Van Deusen, 1978). (XBL 7810-6520)

Figure 26. Audio-magnetotelluric apparent resistivities, north-south telluric orlentation at $7.5 \mathrm{~Hz}$., Klamath Hills area (data from Senterfit and Bedinger, 1976). (XBL 7810-6527) 


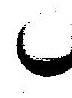


Figure 27. Roving dipole apparent resistivity from Source 6, Klamath Hills area. (XBI 7810-6524)

Figure 28. Roving dipole apparent resistivity from Source 3, Klamath Hills area. (XBL 7810-6530)

Figure 29. Roving dipole apparent resistivity from Source 2, Klamath Hills area. (XBL 7810-6526)

Figure 30. Roving dipole apparent resistivity from Source 4 , Klamath Hills area. (XBL 7810-6525)

Figure 31. Resistivity model 62D. (XBL 7810-6522)

Figure 32. Resistivity model 32D. (XBL 7810-6523)

Figure 33. Source 6 observed data vs. model 62D calculated 54

Figure 34. Source 3 observed data vs. model 32D calculated data. (XBL 7810-6532) 
INTRODUCTION

The Klamath Basin, located in south-central Oregon and northern California (Figure 1), has been the locus of geothermal exploration activities for several years. Exploration interest in this area was stimulated by the presence of numerous hot springs and over 400 wells containing waters of $60^{\circ} \mathrm{C}$ to $115^{\circ} \mathrm{C}$ which are currently used for domestic, institutional, and business heating, and for a few agri-business projects. Three known Geothermal Resource Areas (KGRA's) have been identified in the area (Figure 2): (a) Klamath Falls KGRA north and northeast of the town of Klamath Falls, (b) Olene Gap KGRA east of the town, and (c) Klamath Hills KGRA south of the town. Exploration activities have been conducted by several companies within the KGRA's, as well as within lands adjacent to Klamath Falls. Two unsuccessful deep holes have been drilled thus far in the search for a higher temperature resource suitable for electric power generation, and the general level of interest in the area has consequently declined over the last two or three years.

In an attempt to re-stimulate exploration activity, the Earth Sciences Division Geothermal Group of LBL, working with the State of Oregon's Department of Geology and Mineral Industries (DOGAMI), and the U.S. Geological Survey (USGS), has attempted to collect all available exploration data pertaining to the area, to compile, assess, and interpret them in terms of subsurface geology, and to develop conceptual models for a geothermal reservoir. The end-product of the study is intended to be a document useful to geothermal exploration planners, containing not only an evaluation of the resource potential, but also an assessment 


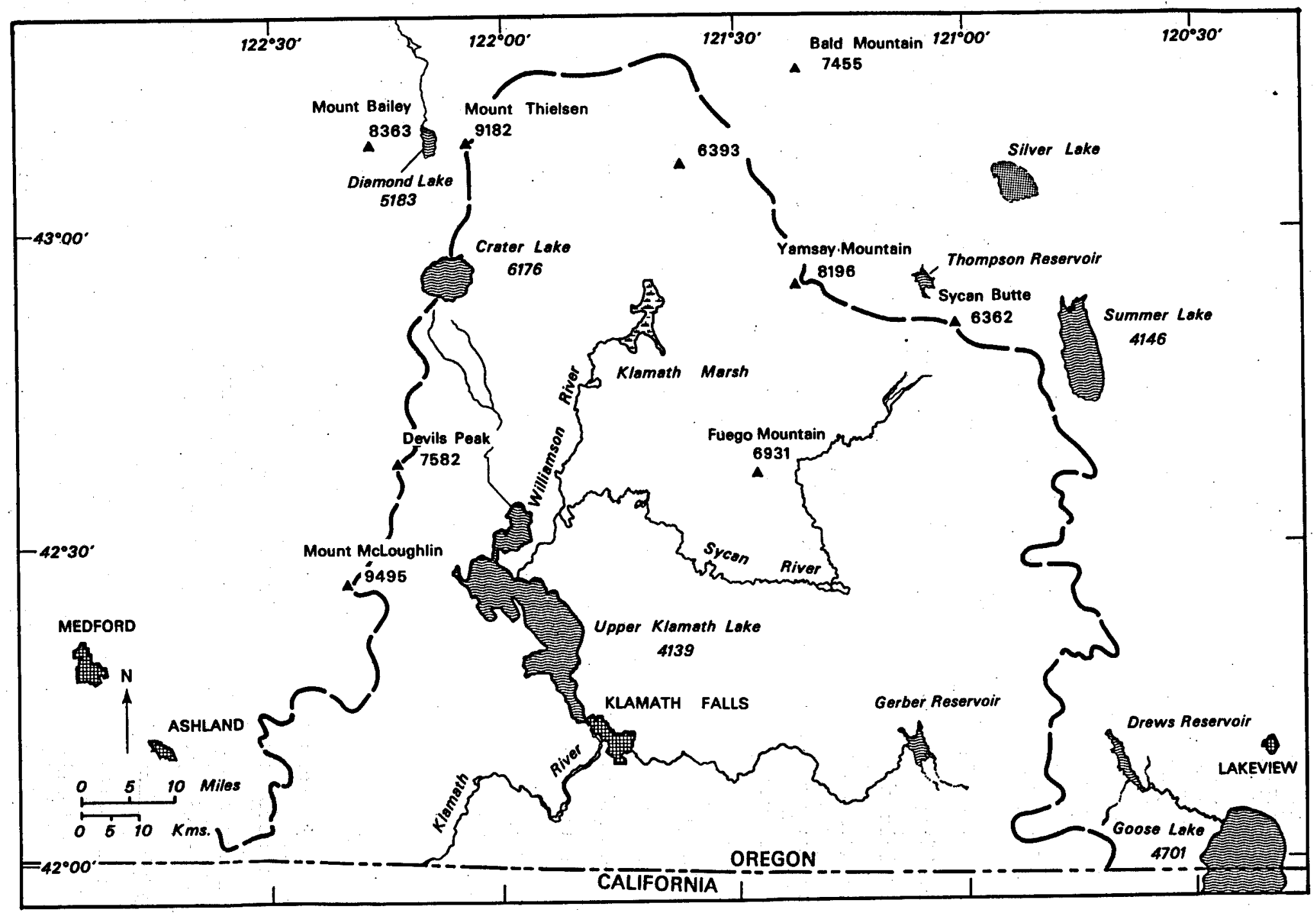

Fig. 1. Klamath Basin.

X BL $784-1822$ 
— Known geothermal resources area boundary

- - Telluric-magnetotelluric survey area (Geonomlas 1977)

-...- Aeromagnetic and gravity survey area. (Van Deusen 1978)

- Roving dipole survey area (Group Seven, 1972)

-..- Audio-magnetotelluric survey area (Senterfit \& Bedinger, 1976)

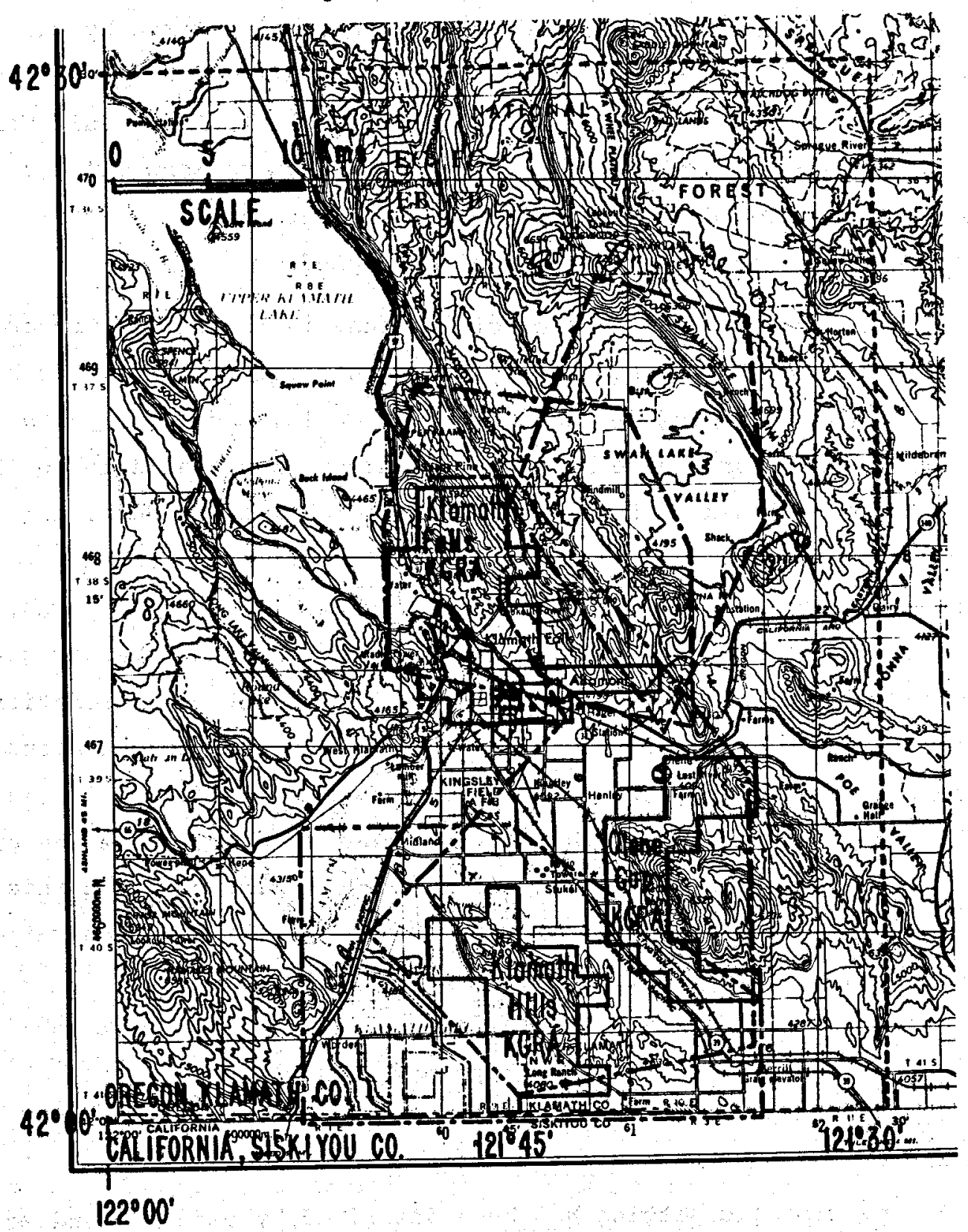

X日L $789-6509$

Fig. 2. Index map showing study areas. 
of exploration techniques and a suggested exploration strategy. This report deals with work performed during the period, June-September 1978.

Data for this work have come from the open literature (e.g., journal articles, university dissertations, and reports by various government organizations) and from files of private companies who made their proprietary, confidential data available to LBL. Gulf Mineral Resources Company, Thermal Power Company, and Creslenn Oil company have contributed data to this study. The data base consists of over 100 relevant documents, listed in the Appendix.

Although the general area of interest is the entire oregon portion of the Klamath Basin (Figure 1), the actual area of study has been restricted to the region around Klamath Falls, the principal area where exploration efforts have been made. Survey data available to LBL cover the areas outlined in Figure 2. The availability of data, more than any other aspect, has directed our initial attention to the two specific areas discussed in this report: (a) the Swan Lake Valley area, and (b) the Klamath Hills area. Because so much of the data are geophysical, this report concentrates primarily on that aspect of exploration. Prior to this study, most of the data received only a cursory examination and preliminary interpretation. We have attempted to do a far more thorough and detailed analysis of the data in order to demonstrate the procedures involved in a proper interpretation, to determine how much information can be extracted, and to evaluate the applicability of the various techniques to the particular exploration problem.

\section{REGIONAL GEOLOGY AND GEOPHYSICS}

\section{Geológy}

The geologic setting has been described by Peterson and McIntyre (1970). The klamath Basin is bounded by the High Cascades to the west, the Medicine Lake Highlands to the south in California, and the high desert country to the east.: The basin is drained by the tributaries of the Klamath River which flows southward into California before discharging into the Pacific Occan. 
Numerous normal faults, trending $N 40^{\circ} \mathrm{W}$, break the area into grabens and horsts. The Klamath graben may be traced for $80 \mathrm{~km}$ from the Medicine Lake volcanic field to Crater Lake. It encompasses Upper Klamath Lake and attains a width of about $15 \mathrm{~km}$. The steeply dipping normal faults have vertical offsets that are estimated to attain 1600 feet in places (e.g., Rattlesnake Point and Stukel Mountain). Although the predominant fault direction is northwesterly, there is geologic and topographic evidence for north- and northeast-trending cross faults which truncate or offset topographic features.

The stratigraphic section in Figure 3 shows Peterson and McIntyre's rock units. The basement rock consists of pliocene basalts of undetermined thickness. These are unconformably overlain by Pliocene Yonna formation, a designation given to a sequence of tuffaceous siltstones and sandstones, lacustrine sediments (mainly diatomites) and basalt flows (Newcomb, 1958), The rocks are subraqueous deposits formed during a period when the region was covered by lakes and swamps. Explosive and quiescent volcanism were nearly contemporaneous with deposition, as evidence by maars, tuffs, and thin basalt flows in the Yonna Formation. Newcomb (1958) reports a maximum observed thickness of about 600 meters for the Yonna Formation.

Late Pliocene and Pleistocene basalt flows and volcaniclastic interbeds are found overlying the Yonna Formation at the higher elevations. Quaternary alluvium covers the valleys. Groundwater aquifers exist in all these rock units, but the Yonna Formation includes impermeable strata which act as confining beds for aquifers below. Upper Klamath Lake averages only $2.4 \mathrm{~m}$ in depth, but contains $7.2 \times 10^{8} \mathrm{~m}^{3}$ of water, which strongly influences the groundwater regime in the Klamath Falls area. The lake water tends to obscure the near-surface thermal gradient in the immediate vicinity of the lake.

The three KGRA's are shown in Figure 2. Klamath Falls KGRA encompasses the principal hot well area covering the town and extends 


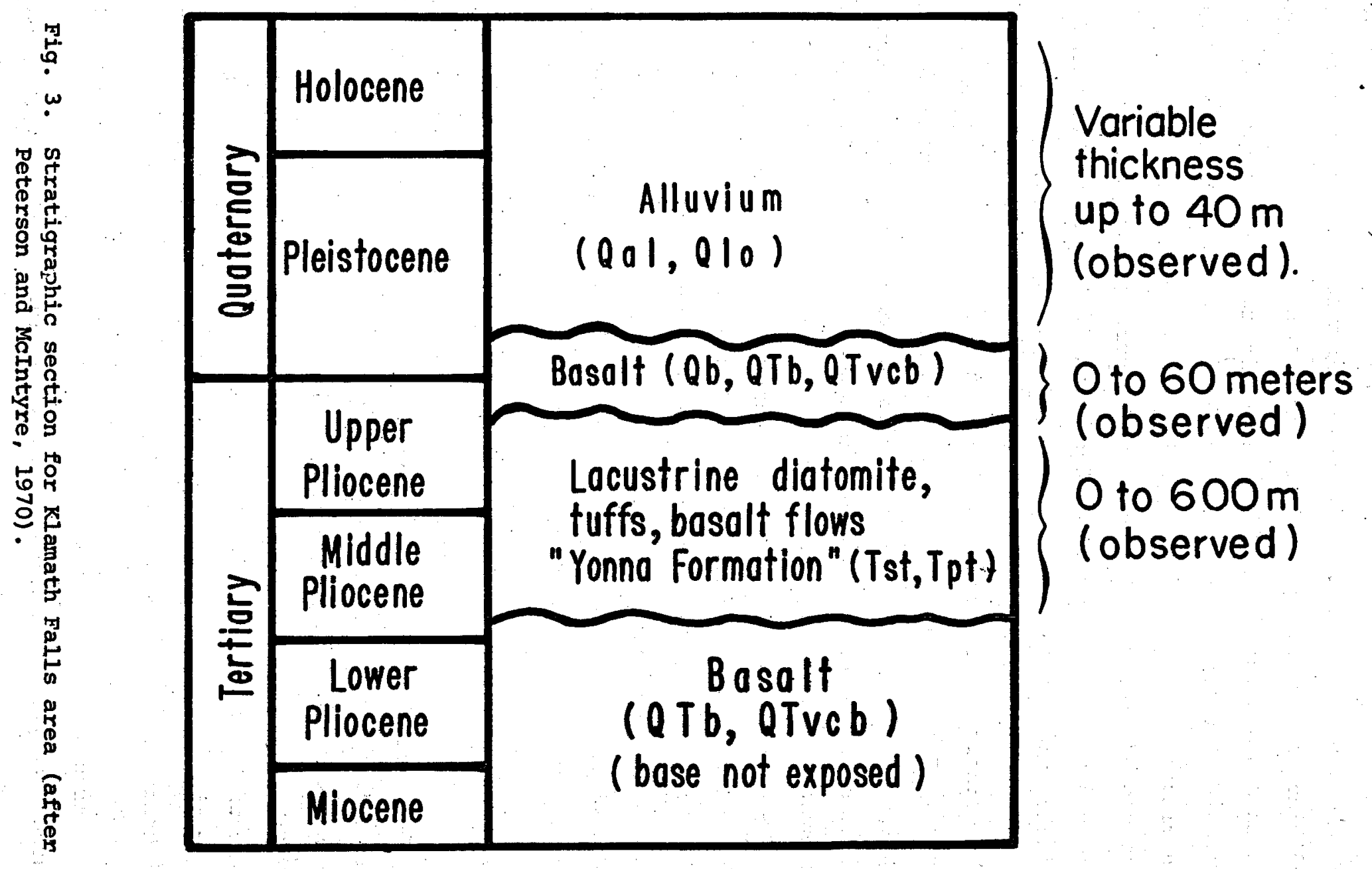

XBL 7810-6540 
east-northeastward. Hot water has been used by the residents, mainly for space heating, since the turn of the century. Presently; approximately 400 shallow wells, most in the 200- to 300-foot depth range, are used to heat 500 structures. Water temperatures range up to $113^{\circ} \mathrm{C}$. The main hot water well area is located adjacent to one of the fault scarps forming the eastern boundary of the Klamath Lake graben.

Olene Gap KGRA covers an area which includes much of the northern and western portion of stukel Mountain. Geothermal manifestations include a few wells and springs with temperatures up to $87^{\circ} \mathrm{C}$ in olene Gap, and a few warm wells with temperatures up to $42^{\circ} \mathrm{C}$ near the northwestern tip of Stukel Mountain.

Sammel (1976) made a minimum reservoir temperature estimate of $130^{\circ} \mathrm{C}$ for the Klamath Falls area, based on several chemical geothermometers.

Geophysics

\section{(a) Aeromagnetic survyes}

Two aeromagnetic surveys, flown for the U.S. Geological survey (USGS, 1972 and 1973), cover the region in Oregon, and have been placed on open-file.

The survey flown by Scintrex Mineral Surveys, Inc. covers the Klamath Falls and Crescent 1:250,000 sheets and all of the area discussed in detail in this report. Geometrics, Inc. flew and compiled the data for the Medford sheet, contiguous to the klamath sheet along the $122^{\circ} 00^{\prime}$ meridian.

The scintrex survey was flown at a constant barometric elevation of 9000 feet, or about 4850 feet above Klamath Lake and the other valley areas, and about 1500 feet above the highest local relief. Lines were flown east-west and at a line separation of approximately two miles $(3.2 \mathrm{~km})$. 
Sharp topographic anomalies are seen to correlate with several of the highest mountains, e.g., stukel Mountain (6525 feet), Edgewood Mountain (6694 feet), and the south end of Hogback Mountain at the lookout tower ( 6000 feet) all give positive anomalies of several hundred to over 1000\%. However, several other prominent anomalies have an unusual relationship to topography which could be explained by strong remanent magnetization. For example, Hopper Hill (5141 feet) at the south end of Swan Lake Valley is a $100^{+} \gamma$ low, and both the dipolar anomalies at Spence Mountain (5841 feet) and at Swan Lake point (7260 feet) suggest a magnetization vector toward the west. In this regard, the magnetic high near squaw point on the west side of Upper Klamath Lake could be due mainly to spence Mountain if its net magnetization were horizontal and to the west.

Not all of the prominent anomalies correlate with topography; however, and these must be due to buried sources. A particular case in point is a broad high, trending northeasterly across Swan Lake valley, one of the areas considered in detail in this report. The maximum is centered near Grizzly Butte (4525 feet) in the northeast corner of the valley, but it seems doubtful that local topography contributes much to the anomaly. Using a simple "half-slope" method for estimating source depth (Nettleton, 1976), we obtain a depth of $500 \mathrm{~m}$ below surface. The Swan Lake Valley anomaly could be a swarm of northeast-trending dikes, but the source is highly conjectural.

Van Deusen (1978) attempted an involved analysis of the aeromagnetic data and an interpretation showing possible areas where elevated Curie isotherms occur. For this work, he performed a "variable continuation" in which gridded data were continued to a constant elevation above average local terrain so as to reduce topographic effects.: We have not checked Van Deusen's interpretations, but we agree with his general conclusion that the data provide little | information useful for geologic mapping purposes, i.e., lithologic and age relationships between volcanics cannot be determined. 
Regarding geological structure, there is a set of magnetic lineaments which trend northwesterly, correlating in places with mapped faults. These lineaments are not as pronounced as one might expect based on the topographic relief developed along many of the northwesterly faults. This could be explained in part by the large average terrain clearance and the large flight line spacing, However, the aeromagnetic data clearly reveal a conjugate set of lineaments trending northeasterly. These also show a correlation to topography, but few mapped faults strike in this general direction. Although the geothermal wells at Klamath Falls occur within an area of many intersecting faults and aeromagnetic lineaments, we have no basis for knowing whether this relationship can be used as an exploration guide elsewhere within the region. In fact, the entire region is characterized by a high density of intersecting faults and magnetic lineaments.

\section{(b) Gravity Survey Data}

Van Deusen (1978) established 465 gravity stations, average spacing $3.5 \mathrm{~km}$, over a $3000 \mathrm{~km}^{2}$ area around Klamath $5 a 11 \mathrm{s.}$. Although his intention was to determine the thickness of young volcanics, this goal proved to be unattainable due to problems presented by topography and lateral changes in subsurface density, In this report we use selected portions of Van Deusen's Bouguer gravity data to estimate the thicknesses of the young, low-density material flliing Swan Lake valley and the valleys bordering the Klamath Hills:

In a regional sense, the Bouguer gravity contours correlate well with the dominant northwest-southeast strike direction. This follows from the fact that gravity lows occur primarily over grabens mantled with lower density sediments, e.g., Upper and Lower Klamath Lakes and Swan Lake Valley. The steepest gravity gradients trend northwesterly and are found on the west flank of the Klamath Hills and at the west end of Agency Lake. Bouguer gravity lows also appear over a few of the mountain peaks (e.g., Hamaker and chase Mountatns, T,40S, R, IW. Secs. 23 and 16). These effects were eliminated after Van Deusen applied an alternate Bouguer reduction scheme in which a variable density was used depending on geology? 
(a) areas of volcanic flows, sediments and alluvium, $2.43 \mathrm{~g} / \mathrm{cm}^{3}$, and

(b) probable young volcanic centers, $2.39 \mathrm{~g} / \mathrm{cm}^{3}$.

instead of a uniform $2.67 \mathrm{~g} / \mathrm{cm}^{3}$, as conventionally assumed.

Regardless of the Bouguer gravity reduction scheme used, gravity contours reveal major $N 50^{\circ}-60^{\circ} \mathrm{E}$ lineaments as do the aeromagnetic data. The strongest of these are:

(1) Olene Gap lineament, running from Pleasant Valley (California) on the southwest, across Lower Klamath Lake, and through Olene Gap.

(2) Klamath Falls lineament, running through the City of Klamath Falls, and along the southern borders of Meadow Lake and Swan Lake Valleys.

Both gravity lineaments conform, in part, to topographic expressions, but traverse rocks of different age and composition. Concordance between lineaments and mapped faults is minor; Peterson and McIntyre (1970) show only short fault segments on line with the olene Gap lineament. However, the Olene Gap lineament is also marked by a number of young basaltic volcanic centers spaced at intervals of 20 to $30 \mathrm{~km}$, and therefore it is impossible to discount the relation and importance of northeast-trending fracture zones on the regional thermal regime.

(c) Magnetotelluric Survey Data

Tang (1974) reported on a magnetotelluric program that included telluric measurements at 17 sites, only 10 of which provided data, in the Klamath Falls area. For all measurements the magnetic field was measured in Corvallis; $220 \mathrm{~km}$ from the area of investigation, Remote telluric measurements such as these require (a) a uniform primary magnetic field over a large area and (b) little or no spatial variations in the secondary magnetic fields at any of the stations due to induced currents, Because the second condition does not occur in 
areas of complex geology, the accuracy of the method for determining subsurface resistivities is always in doubt unless verified by careful experiment. Also, because a very limited amount of scalar data were obtained and analyzed, and only in the 20-50 sec. band, we cannot place any confidence on Tang's interpretations. At one station in Swan Lake Valley where we have good tensor MT data for comparison. Tang's values for apparent resistivities appear to be in rough agreement, however, Tang offered the tentative conclusion that "the apparent resistivity data observed in the Klamath Falls area are low when compared to normal crustal values... The data are therefore indicative of an enhanced electrical conductivity probably due to elevate (sic) subsurface temperature in the region,"

\section{SWAN LAKE VALIEY AREA}

Topography and General Geology

Located 10 to 18 kilometers northeast of Klamath Falls, Swan Lake Valley is a flat, roughly rectangular valley bounded on all sides by mountains, except for an opening near its southern corner (Figure 4). Swan Lake itself lies near the northeastern edge of the valley, forming a natural sump for streams flowing from the north and west. The valley is a closed hydrologic basin under normal conditions, swan lake Rim, rising more than 300 meters over the valley floor, bounds the valley to the northeast. To the southwest lies the smaller Meadow Lake valley which is considered a part of the swan Lake valley area in this report.

Both valleys are grabens, bounded by northwest-trending, steeplydipping normal faults and filled with Quaternary alluvium and Yonna Formation rocks (Figure 5). Cross-faults, suggested in the aeromagnetic data, may truncate the valleys on the northwest and southeast edges, but none have been identified in published geologtc maps. The surrounding mountains are composed primarily of Yonna Formation rocks and P1iocene basalt flows. 


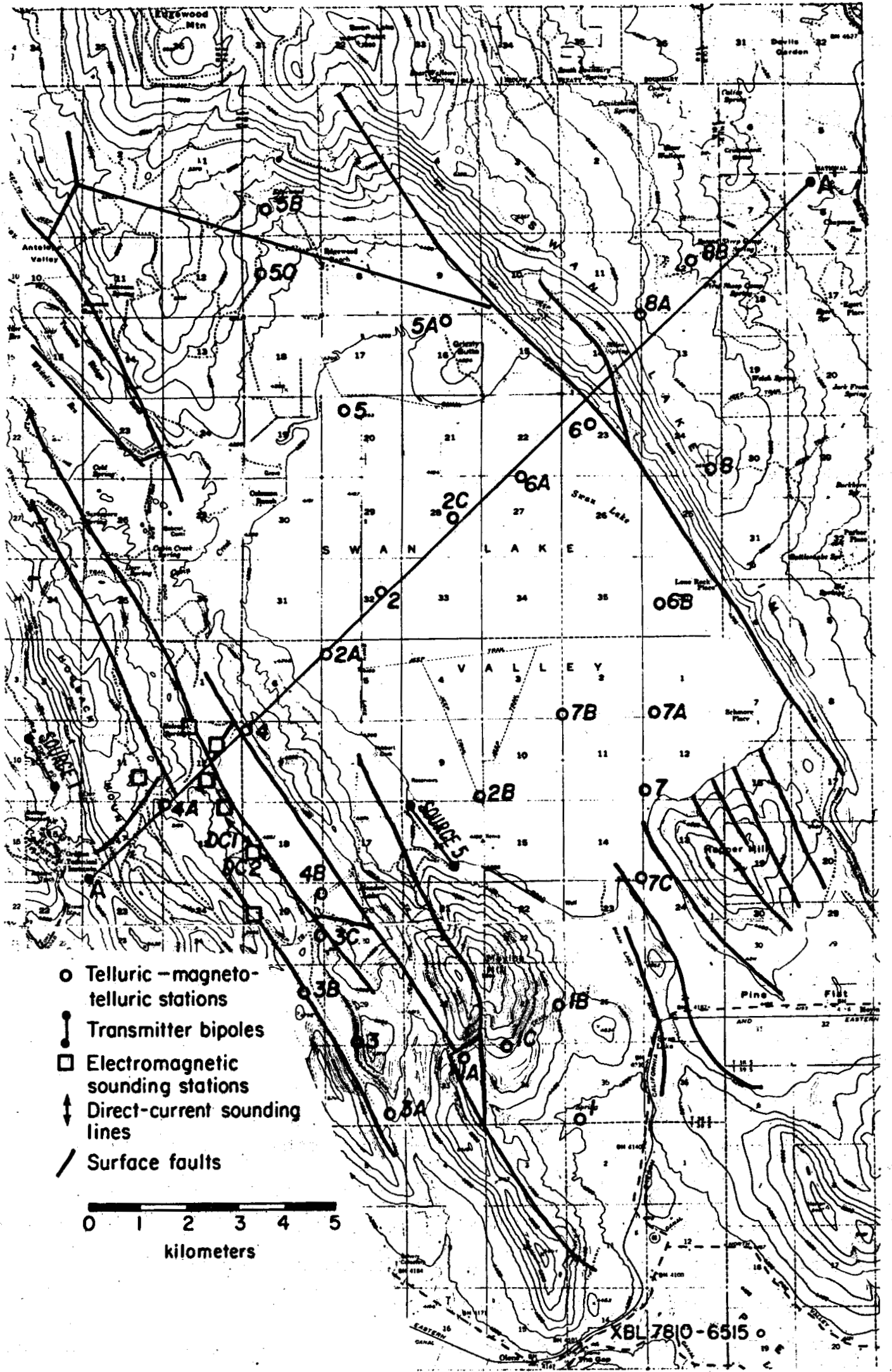

Fig. 4. Swan Lake Valley Base Map 


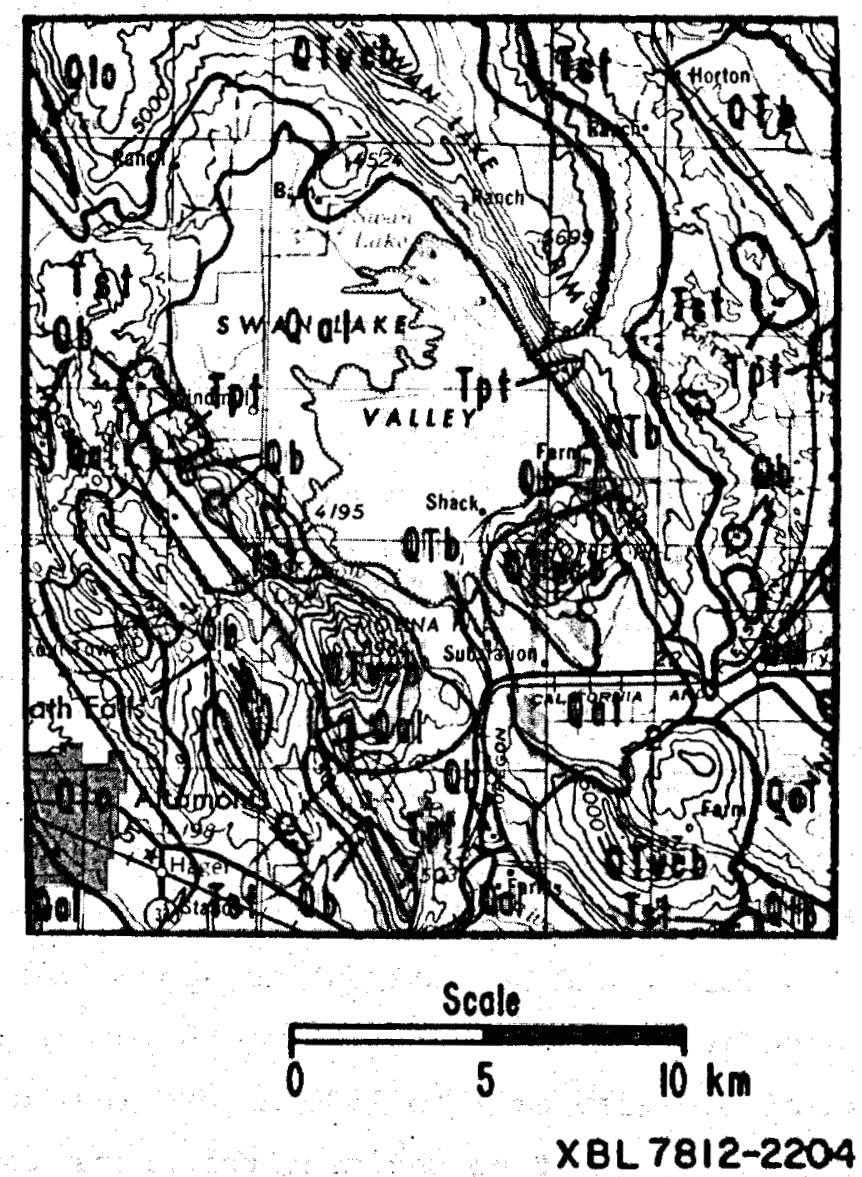

Fig, 5, Swan Lake Valley Geologic Map 
Holcomb Spring, near the northern end of Meadow Lake Valley, produces warm water (Geonomics, 1977).

\section{Gravity Survey}

Van Deusen (1978) made gravity measurements at about 20 stations in the area as part of his regional study. In his thesis, he presented the gravity data in three forms: free air anomaly, complete Bouguer anomaly with Bouguer density of $2.67 \mathrm{~g} / \mathrm{cm}^{3}$, and a variable density Bouguer anomaly. In our interpretations we have dealt only with the complete Bouguer anomaly, density $2.67 \mathrm{~g} / \mathrm{cm}^{3}$, and the Swan Lake Valley segment is reproduced in Figure 6 .

A gravity low dominates the Swan Lake Valley, presumably caused by the density contrast between valley sediments and the surrounding basalts. Van Deusen modeled valley structure beneath profile B-B' (Figure $7 \mathrm{~b}$ ). Using a density contrast of $1.0 \mathrm{gram} / \mathrm{cm}^{3}$ he found the sediment thickness to be about 300 meters. However, he stressed that this thickness is a minimum value because the assumed density contrast may be too large.

We constructed the profiles in Figures $7 a$ and $7 c$ along lines $A-A^{\prime}$ and C-C' from Van Deusen's contours in order to apply a "glacial thickness" formula (Grant and West, 1965) to approximate sediment thicknesses. These are found to range from 350 meters (using a density contrast of $1.0 \mathrm{gram} / \mathrm{cm}^{3}$ ) to 1500 meters (using a density contrast of $0.3 \mathrm{~g} / \mathrm{cm}^{3}$ ). The true sediment thickness probably lies between these values.

The steepest gravity gradients occur on the east and southeast sides of the profiles, suggesting a major vertical fault offset associated with the Swan Lake rim. Gradients westward (Figures $7 \mathrm{a}$ and 7c) are gentler. As Van Deusen (1968) noted this could be caused by the $2.67 \mathrm{~g} / \mathrm{cm}^{3}$ Bouguer density. If this value is too large, it will erroneously depress Bouguer gravity values, particularly in areas of fractured low density rock such as we might expect in the Meadow Lake Valley - Hogback Mountain area. 


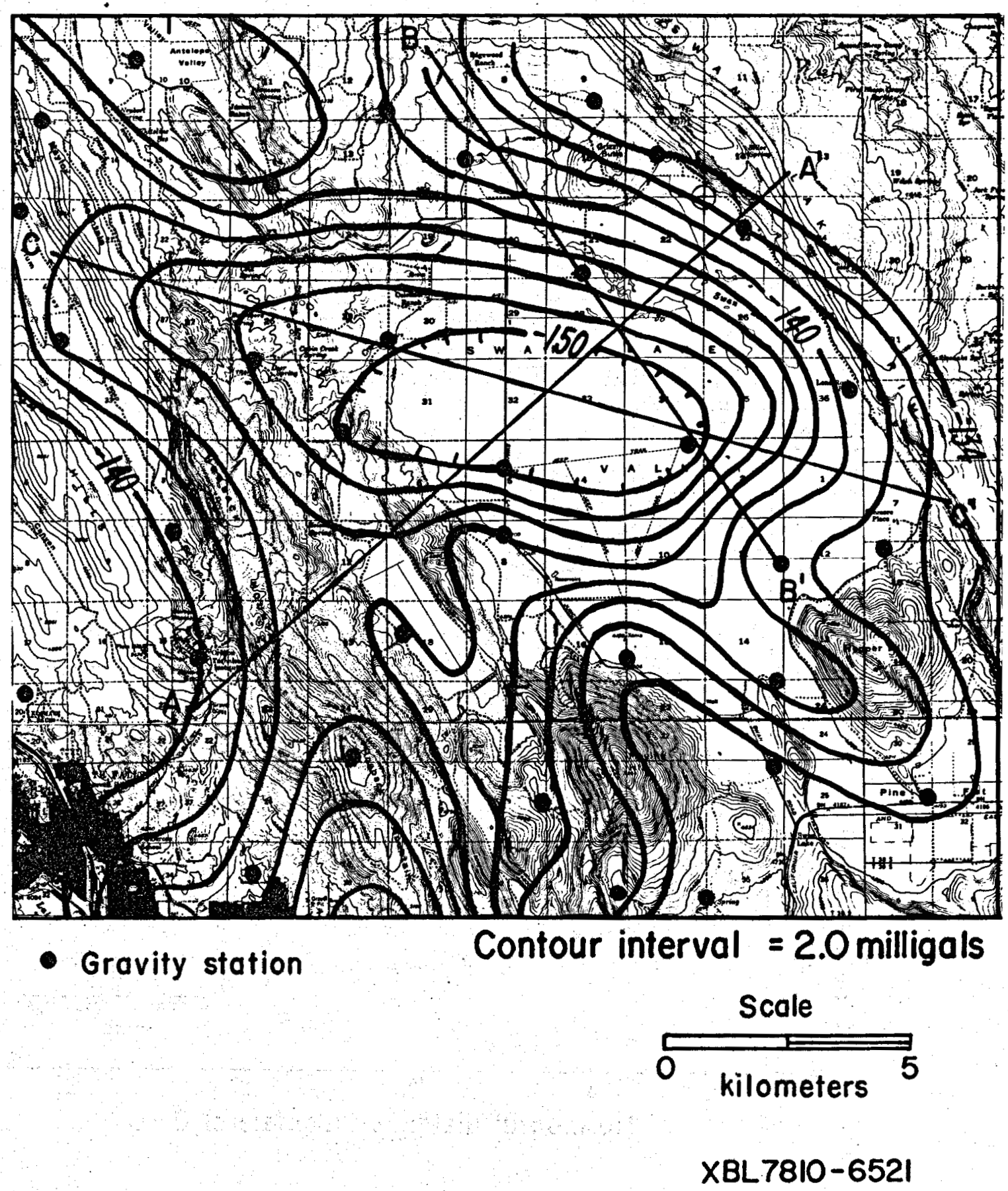

Fig. 6. Complete Bouguer gravity contours, Swan Lake Valley (after Van Deusen, 1978). 

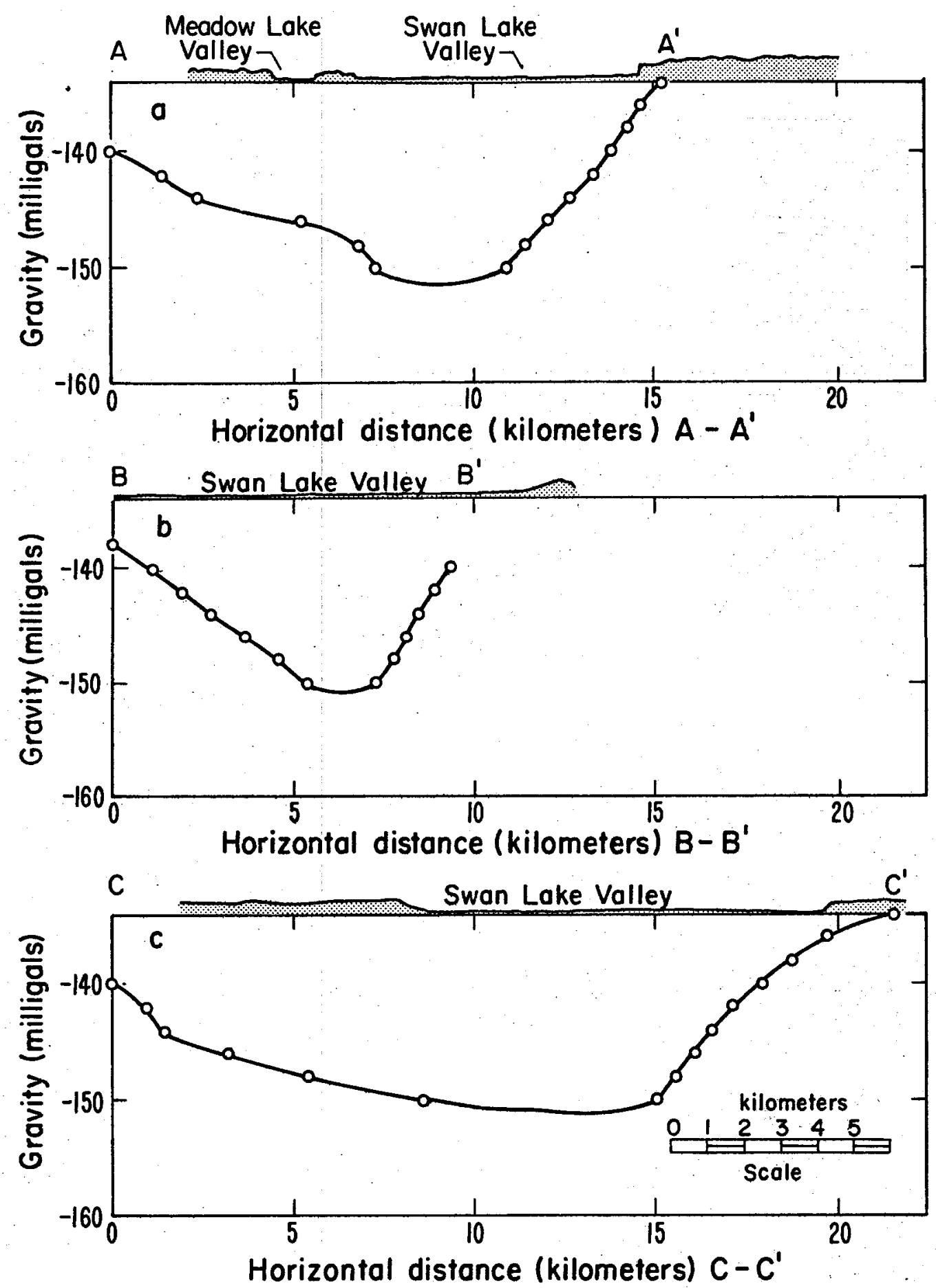

XBL 789-6510

Fig. 7. Three gravity profiles across Swan Lake Valley. 
Another possibility is that the fault at Swan Lake Rim has undergone greater displacement than those on the southwest margin of the valley. This is consistent with the regional geology if Swan Lake Valley and Meadow Lake Valley are seen as parasitic sub-grabens on the eastern flank of the larger Klamath Graben.

Figure 6 includes part of the Klamath Falls gravity lineament mentioned earlier. The lineament trends $\mathrm{N}^{\circ} 0^{\circ} \mathrm{E}$ through Klamath Falls, Meadow Lake and along the southeast side of Swan Lake Valley.

\section{Aeromagnetic Survey}

Using the Open File aeromagnetic survey (USGS, 1972) Van Deusen (1978) applied a variable continuation scheme to approximate aeromagnetic data flown at a constant height above terrain. Both the original and variable-continued data show a magnetic high over the north end of Swan Lake Valley centered near Grizzly Butte (Figure 8). other than this magnetic anomaly, there is generally good conformance between gravity and aeromagnetics in the area. This leads us to the speculation that the magnetic anomaly may be caused by highly magnetic dikes within the volcanics underlying the valley. A rough depth estimate for the source is $500 \mathrm{~m}$ below the surface. The source appears elongate in a northeasterly direction, subparallel to the Klamath Falls gravity lineament which manifests itself in Figure 8 as an aeromagnetic lineament as well.

Roving Dipole, Electromagnetic and Direct Current Resistivity Sounding Surveys

Group Seven Incorporated (1972) performed roving dipole, direct current (dc) resistivity soundings, and electromagnetic (EM) sounding surveys in an area which included the western quarter of the Swan Lake Valley area. Figure 4 shows the locations of bipole sources, dc resistivity sounding lines and EM stations occupied. Approximately 50 pairs of dipole receivers were located in the Swan Lake Valley area. The receivers measured voltage drops relative to sources 1,5 (Figure 4) or 8 (outside the area and now shown in Figure 4) or, in some cases, 


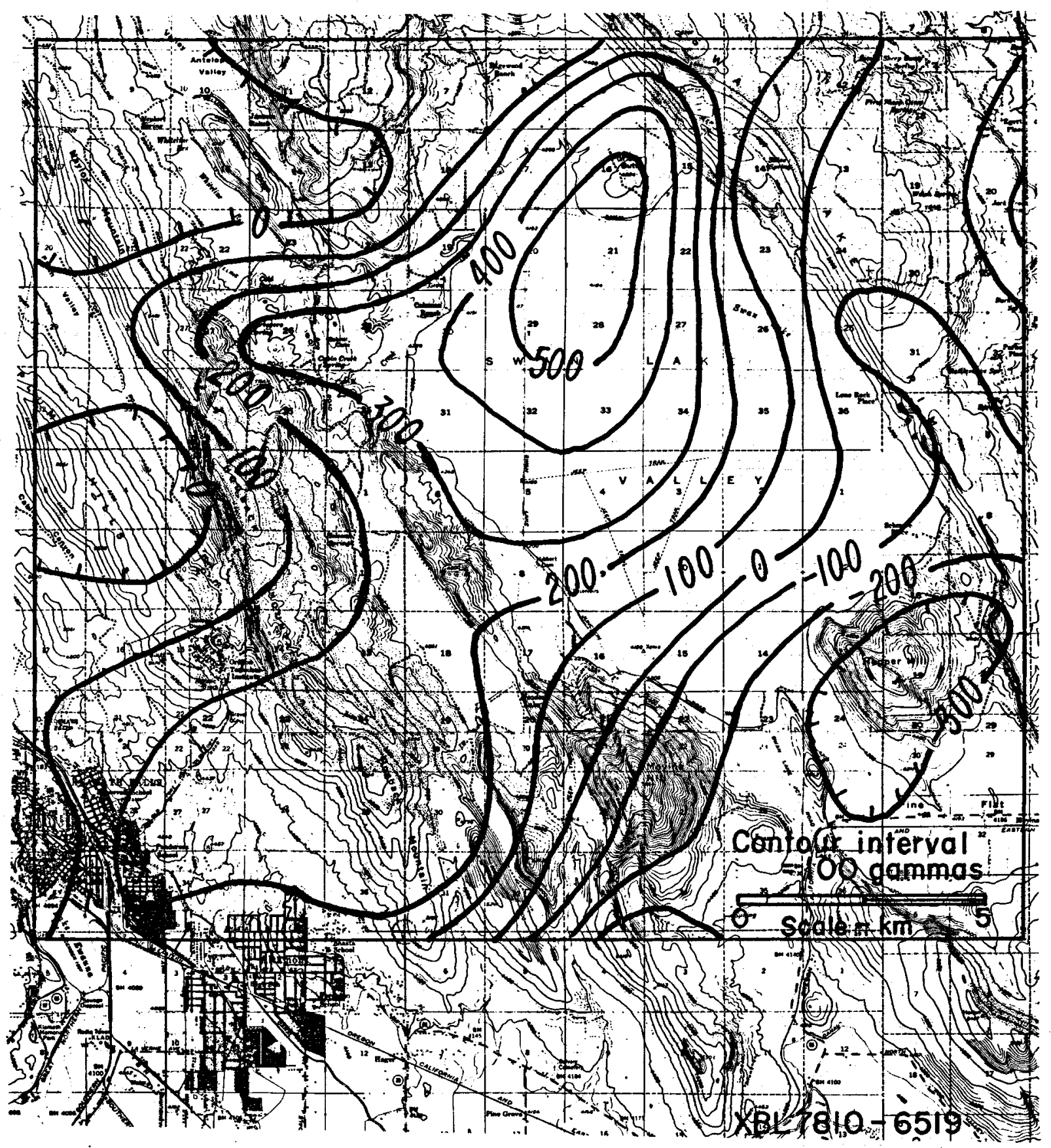

Fig. 8. Total intensity magnetic field variable-continued to 2000-foot elevation above land surface, Swan Lake Valley (after Van Deusen, 1978). 
from two or three sources. The calculated apparent resistivities were then, plotted at the receiver locations and contoured. Where measurements were obtained relative to multiple sources the apparent resistivities were averaged.

We replotted the data from each bipole separately in order to apply one- and two-dimensional modeling techniques. Figures 9, 10, and 11 show the contoured apparent resistivities from Sources 5, 1, and 8 , respectively. One by-product of the separation was the emergence of a low apparent resistivity zone in the Klamath Falls "steamer zone." This can be seen in Figures 10 and 11 . This low does not appear on Group Seven's apparent resistivity map of the averaged readings.

We attempted one-dimensional curve-matching along line 5P (Figure 8), which runs along the western margin of Swan Lake Valley. This was seen as the only area which might be suited to one-dimensional interpretation. The observed curve was matched against theoretical two-layer curves, and the best model indicates a drop in resistivity from $185 \mathrm{ohm}$-meters to $30 \mathrm{ohm-meters} \mathrm{at} \mathrm{a} \mathrm{depth} \mathrm{of} 1$ kilometer (Figure 12).

We then used program RESIS2D (Dey, 1976) to compute theoretical apparent resistivity maps for two-dimensional models striking perpendicular to line 52D (Figure 9). Guided by our magnetotelluric interpretation for the area (discussed in the next section), we performed several iterations of program RESIS2D, arriving finally at the twodimensional Model 52D (Flgure 13). Figure 14 compares the calculated apparent resistivity contours with the observed data. The agreement is good in a gross sense. Fine details in the observed data are probably due to the effects from small surface inhomogeneities which cannot be modeled in two dimensions.

The model represents the Meadow Lake graben flanked by the western edge of Swan Lake Valley to the northeast, and by Hogback Mountain to the southwest. Meadow Lake graben is a conductive feature (5 ohm-meters) of large but undetermined depth extent. Flanking the graben resistant basement ( $2000 \mathrm{ohm}$-meters) is encountered at a depth of 1.4 kilometers. This two-dimensional model is consistent with the one-dimensional interpretation discussed above and shown in Figure 12. 


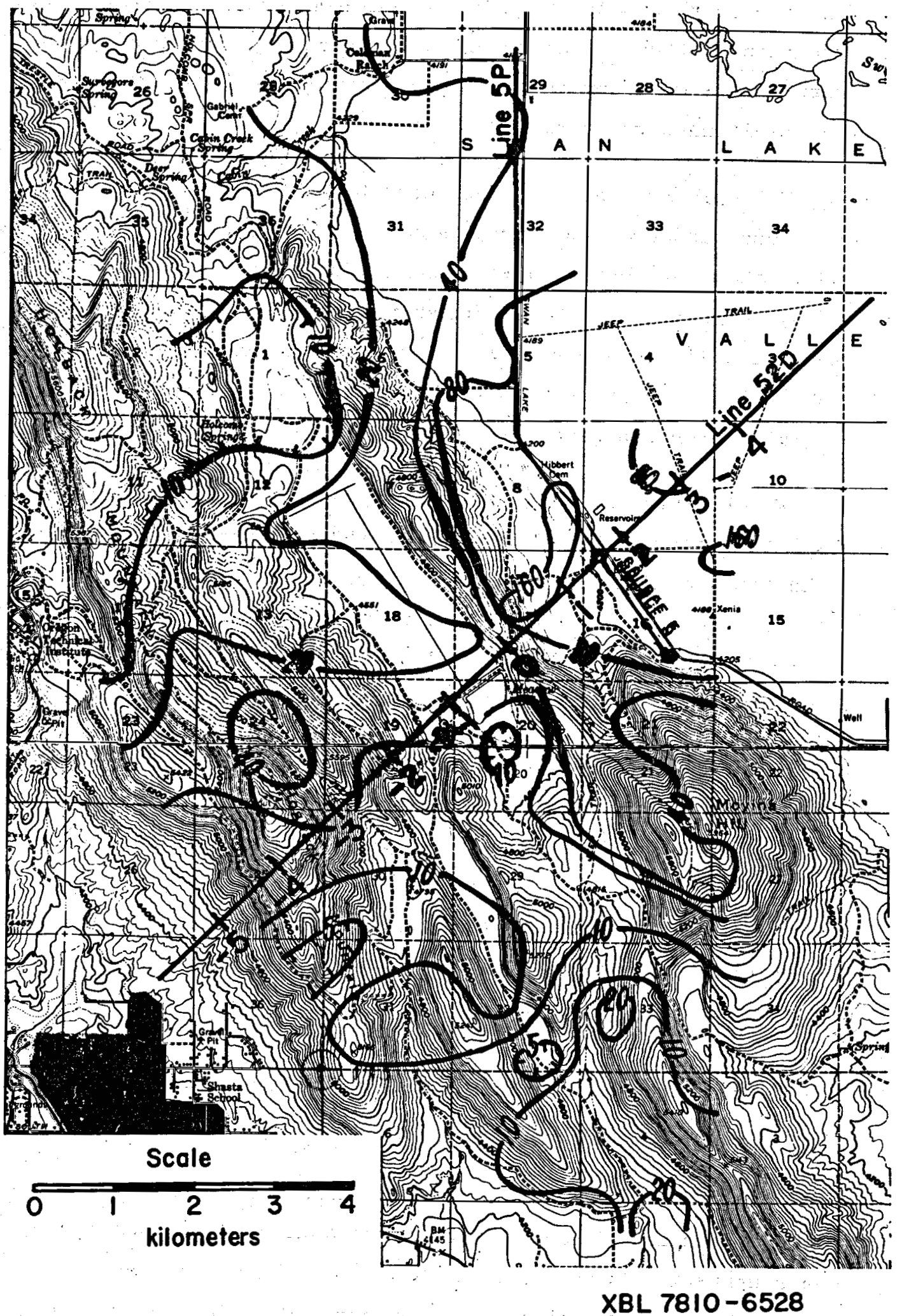

Fig: 9. Roving dipole apparent resistivity from Source 5, Swan Iake Valley: 


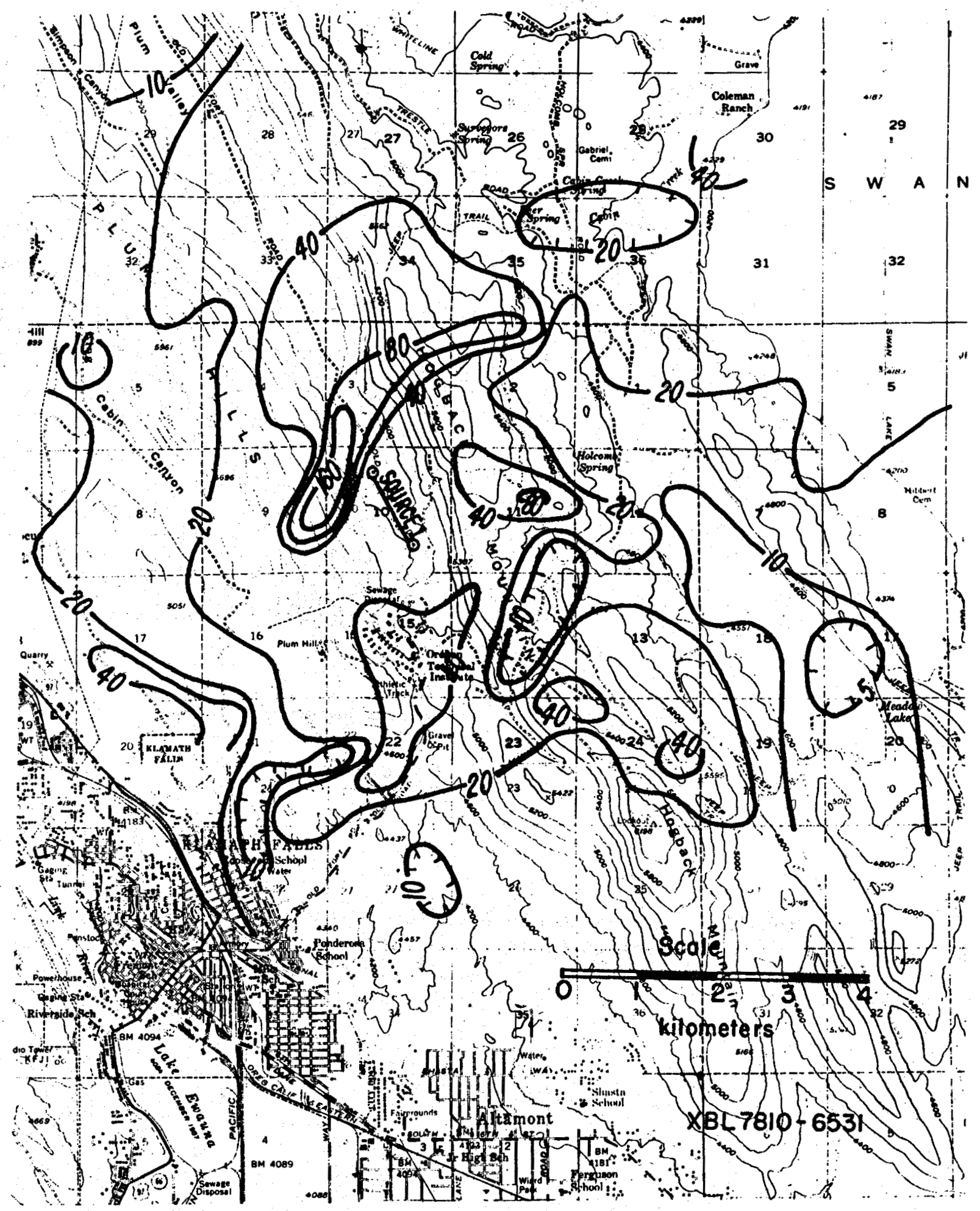

Fig, 10. Roving dipole apparent resistivity from Source 1, Swan Lake Valley. 

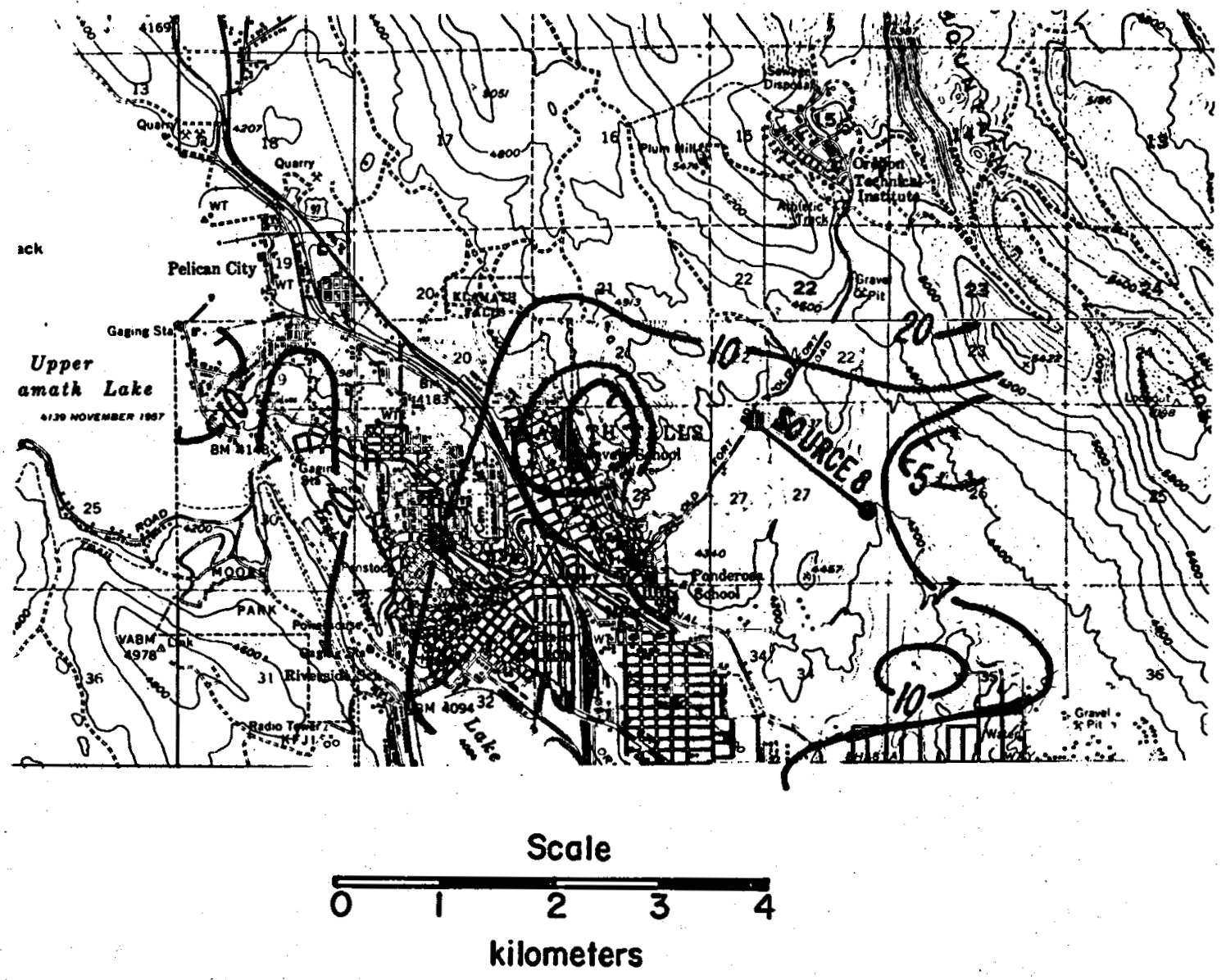

XBL 7810-6529

Fig. 11. Roving dipole apparent resistivity from Source 8, Klamath Falls area. 


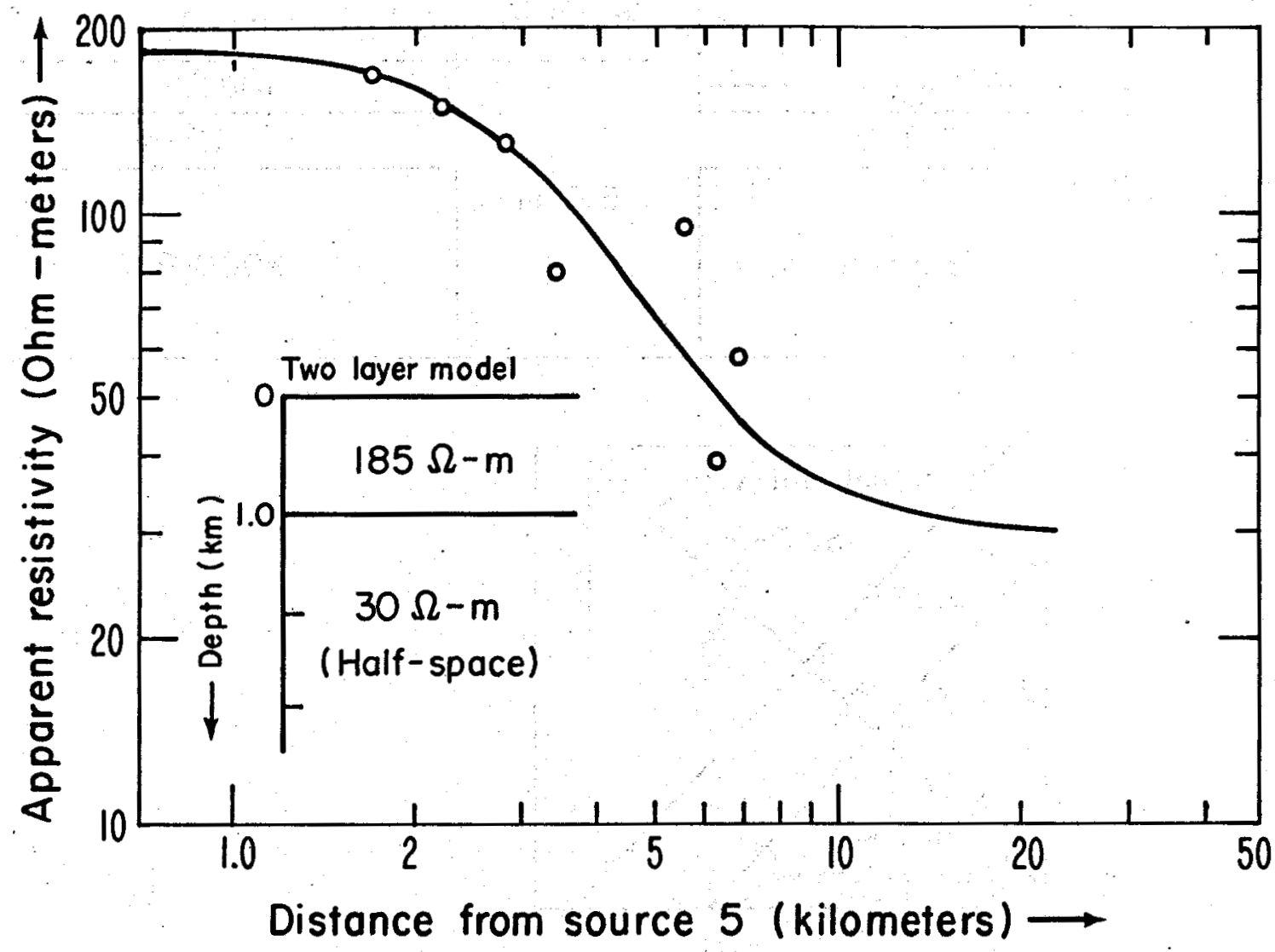

XBL $7810-6516$

Fig. 12. Roving dipole profile along line 5P, with two-layer model, Swan Lake Valley. 

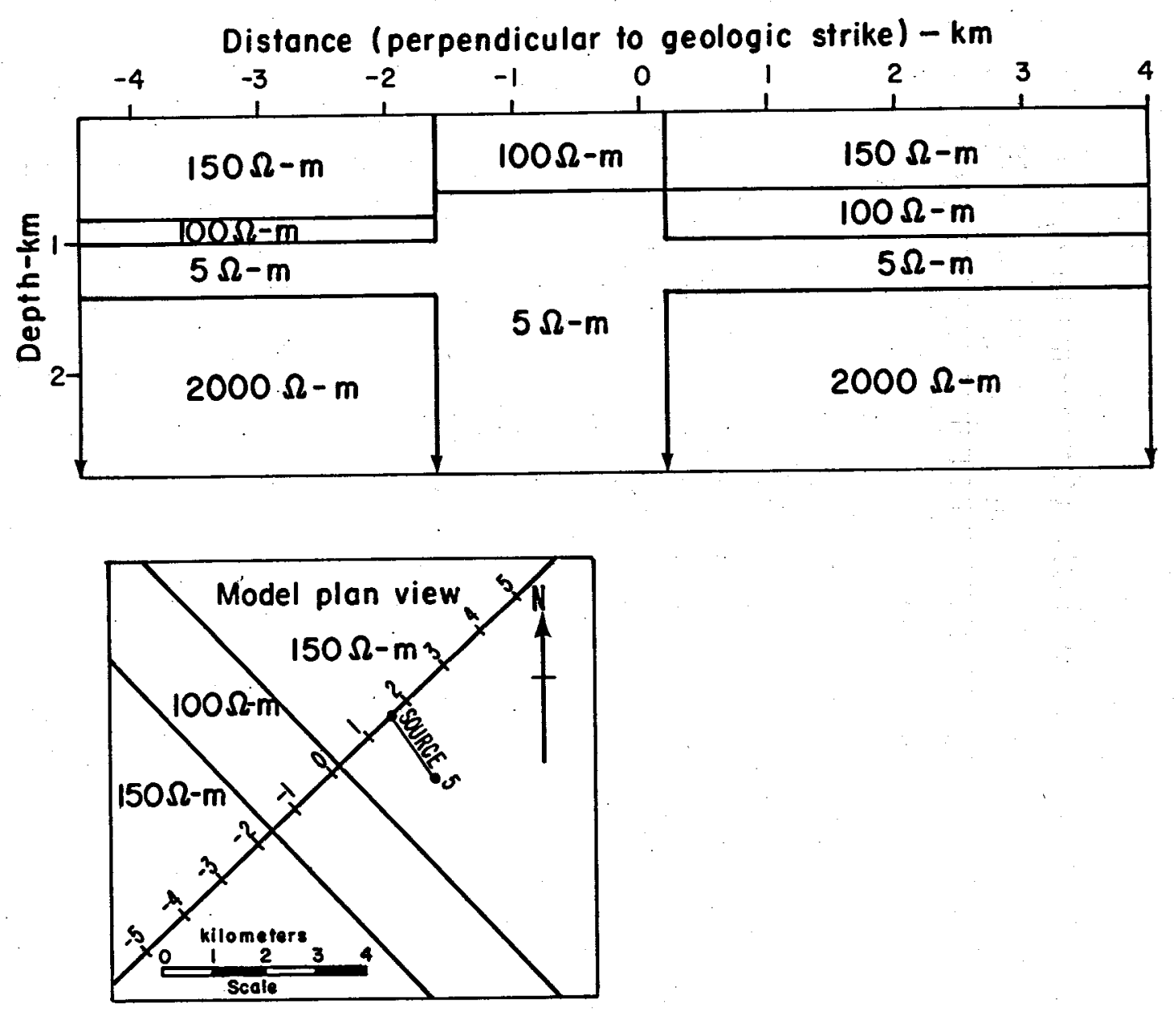

$X B L 7810-6518$

Fị, 13, Resistivity model 52D. 


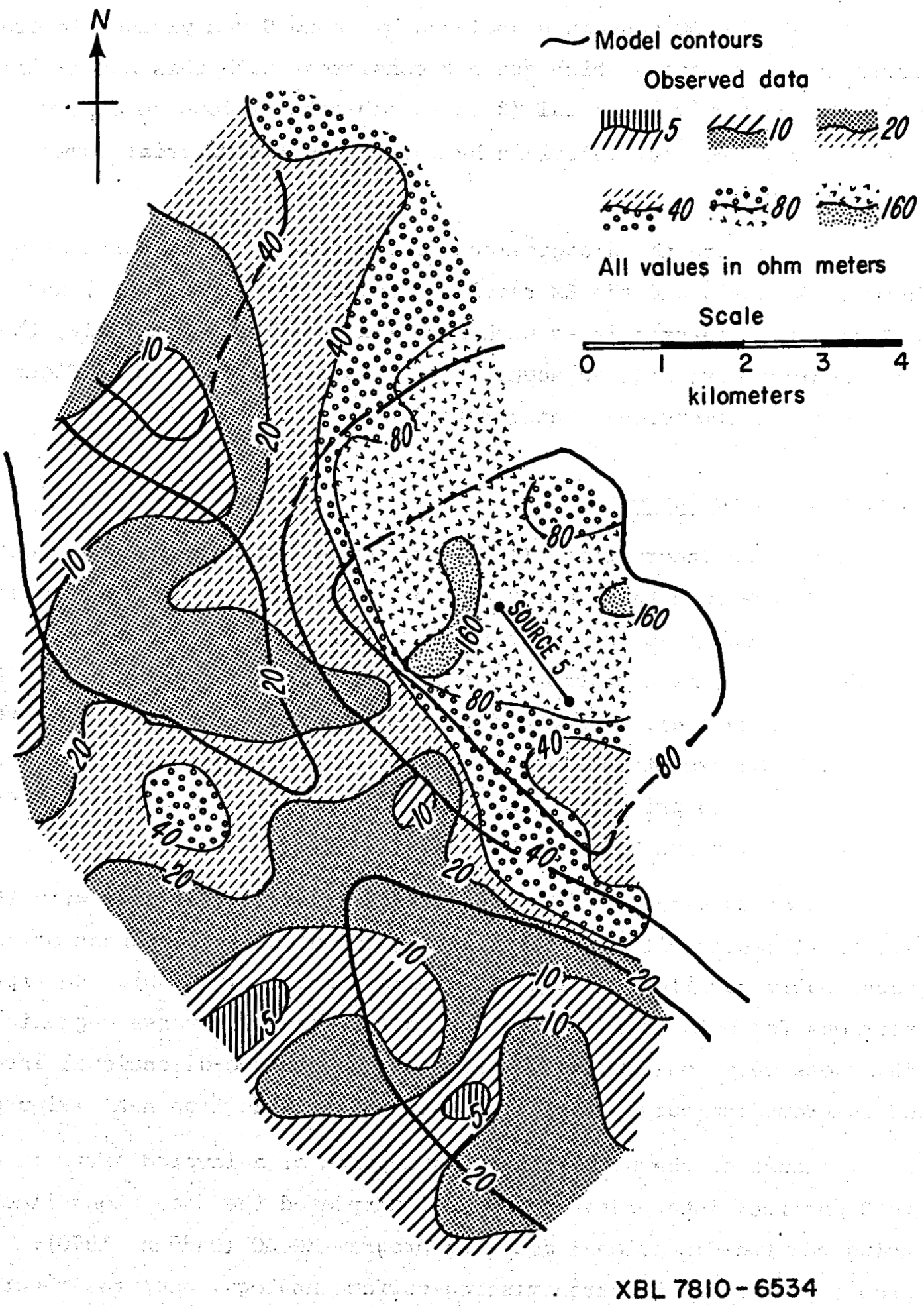

Fig. 14. Source 5 observed data vs. model 52D calculated data. 
The EM and DC soundings analyzed by Group Seven yielded layeredearth interpretations which are not consistent with this model; they indicate conductive material (5 to $40 \mathrm{ohm}$-meters) down to depths of a few hundred meters, underlain by more resistive material (over 100 ohm-meters).

We attribute the disagreement to the fact that the earth structure between Source 5 and the EM receivers is not one-dimensional, and attempts to interpret it as such have led to error. similarly, the dc soundings were made adjacent to or across a mapped fault (Figure 4), so these one-dimensional interpretations are also questionable.

\section{Magnetotelluric Survey}

Geonomics Incorporated (1977) conducted a telluric-magnetotelluric survey in the Swan Lake Valley area in September 1977. Tensor sounding curves were obtained for 29 stations, of which 8 were five-component magnetotelluric base stations and 21 were two-component remote telluric stations (Figure 4). Judging from the Geonomics report, data quality appears to be exceptionally good; smooth and complete sounding curves, rotated into the principal resistivity directions, were obtained for the frequency range 0.01 to $50.0 \mathrm{kz}$.

Geonomics associated the transverse electric (TE) mode with the principal resistivity direction having the electric component oriented more nearly parallel to regional geologic strike $\left(\mathrm{N}_{4} 0^{\circ} \mathrm{W}\right)$. Interpreted sections for both transverse electric (TE) and transverse magnetic (TM) data sets were constructed by linking together one-dimensional inversions of the sounding curves for each station along the line A-A' (Figure 4).

Because of the questionable assumption of a layered earth inherent in Geonomics' interpretation, we reinterpreted the data along line $A-A$ ' using the two-dimensional modeling program EMCDC (Madden, 1970). This program, based on the transmission-surface analogy, computes theoretical TE and TM soundings at selected points along a line perpendicular to a specified earth resistivity model. Model parameters are adjusted until the calculated TE and TM soundings at each station match the corresponding observed soundings. Best fits are determined visually 
by comparing pseudo-sections of apparent resistivity plotted at each period for each station (e.g., Figures 16 a and b).

There was some uncertainty regarding mode identification. The scientist in charge of processing these data for Geonomics indicated that the TE and TM modes might have been misidentified at stations 4 , 8A, and 8B (I.K. Reddy, personal communication, 1978). In this light we revised the observed apparent resistivity pseudo-sections by interchanging the TE mode with the TM mode at the stations in question. Comparisons of Figures $16 \mathrm{a}$ and $17 \mathrm{a}$ with Figures $19 \mathrm{a}$ and $20 \mathrm{a}$, respectively, show the resulting differences. To account for the two possible data sets, two separate models were sought. The models derived are called OMI (original mode identification) and SMI (switched mode identification). The models are shown in Figures 15 and 18 and their calculated TE and TM pseudo-sections are shown in Figures $16 \mathrm{~b}, 17 \mathrm{~b}, 19 \mathrm{~b}$ and $20 \mathrm{~b}$. Twodimensional models were fitted to the $\mathrm{TE}$ data sets as these are more amenable to interpretation than the TM data sets.

Lastly, we performed a two-dimensional inversion on the switchedmode data, using program SM2D (Jupp, 1976). This program iterates the forward modeling program EMCDC a specified number of times, changing the resistivities of each block at each iteration based on computed partials for inversion. That is, after an initial model is submitted, the program finds a better model with the same electrical boundaries but with different resistivity values. The TE and TM modes are inverted simultaneously, so the final model is a "best fit" for both modes.

After five iterations on Model SMI, the inversion program yielded Model ISMID (Inverted Switched-Mode Identified Data). The model is shown in Figure 21 and its calculated $\mathrm{TE}$ and $\mathrm{TM}$ pseudo-sections are shown in Figures $22 a$ and $b$, The TM pseudo-section for ISMID is $a$ definite improvement over those for SMI and OMI, but the TE pseudosection for ISMID does not fit as well as those for SMI and OMI.

Although the two-dimensional modeling approach is a major improvement over one-dimensional inversion, the true subsurface structure is 


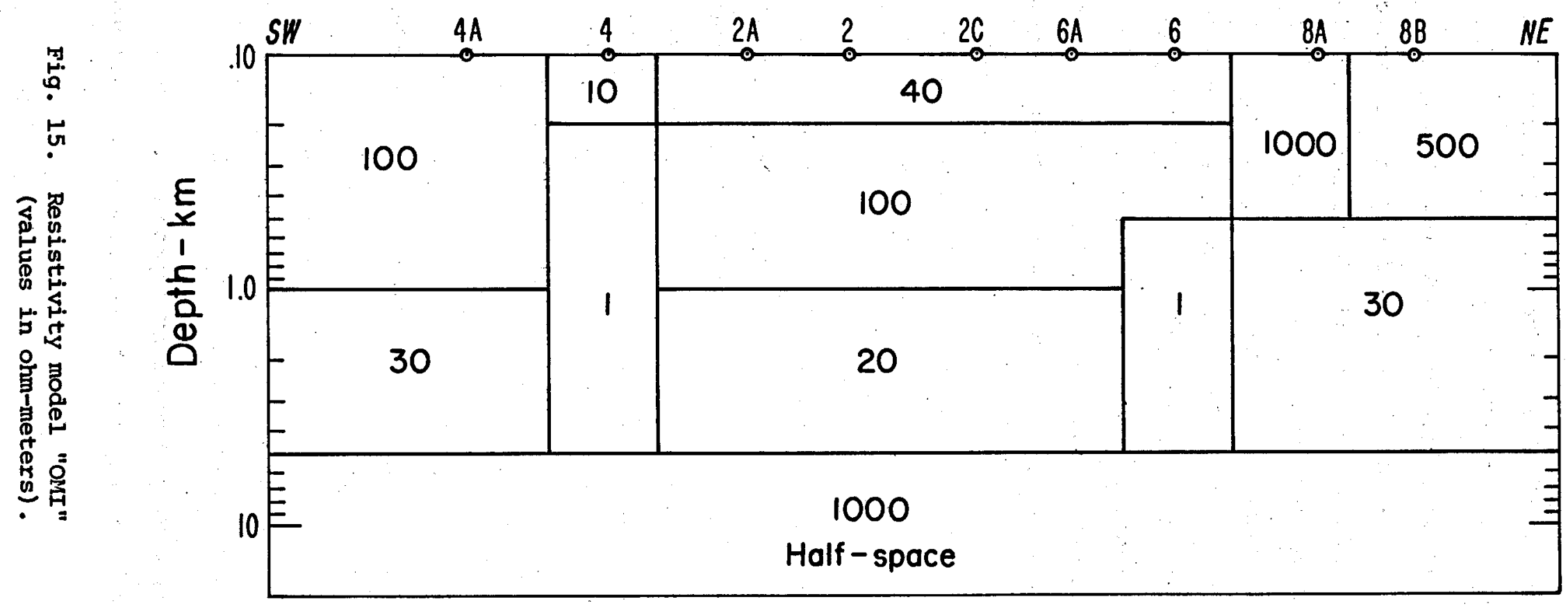

Horizontal scale

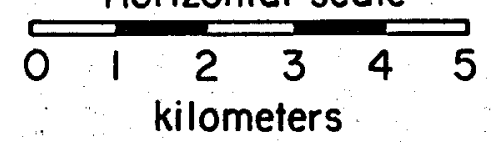

$X B L 789-6513$ 


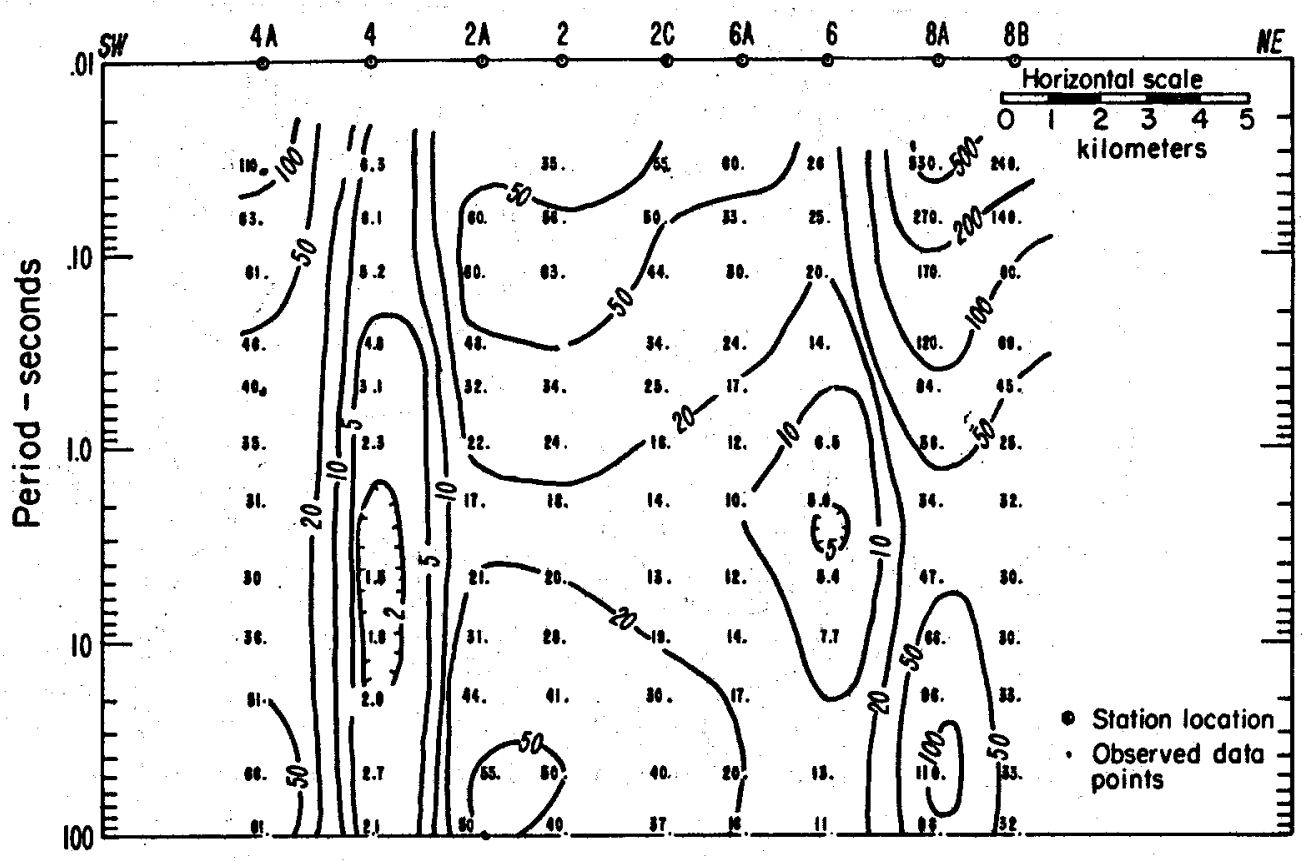

Fig. 16a

$X B L 789-6511$

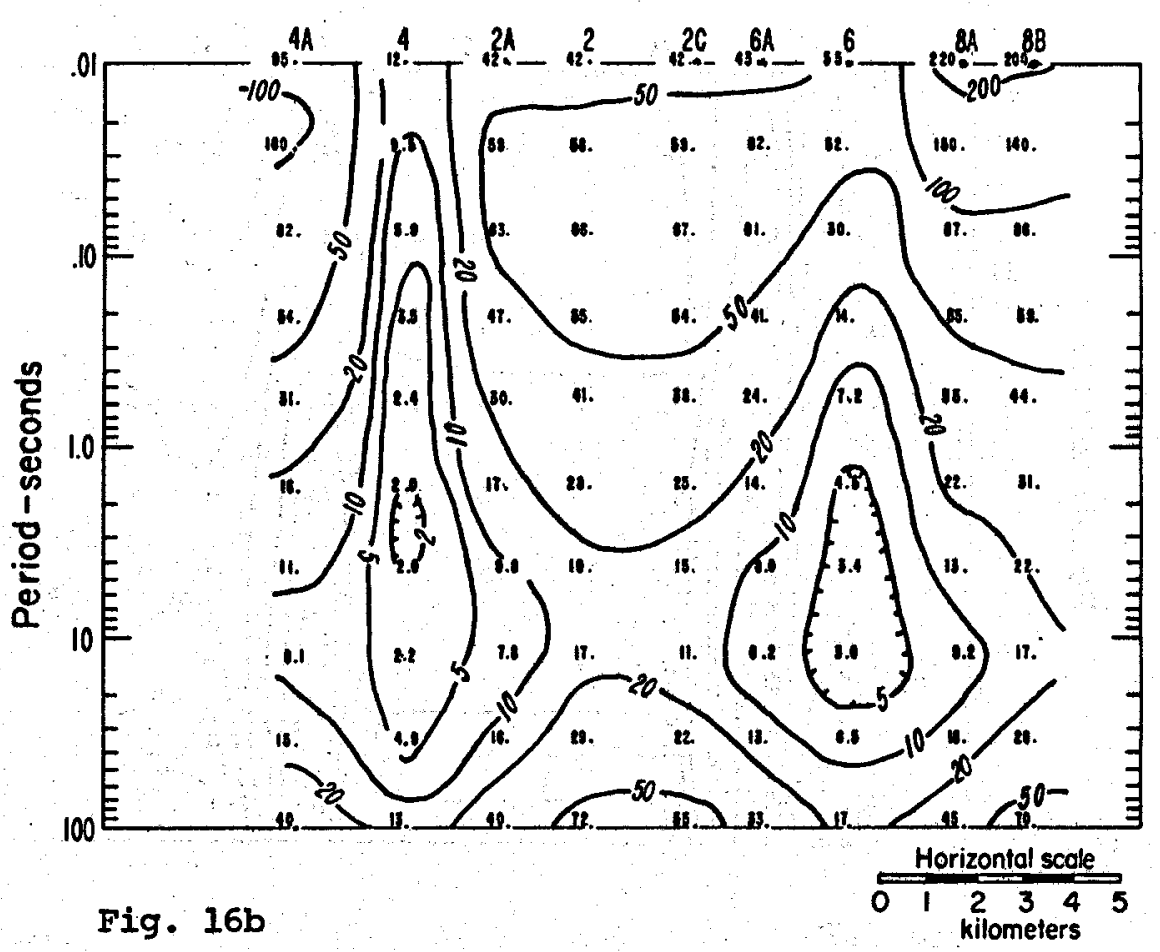

XBL 789-6514A

Fig. 16. TE mode apparent resistivity pseudorsections, Line A-A', Swan Lake Valley 16a. Observed data. 16b. Calculated values for model "OMI" . 


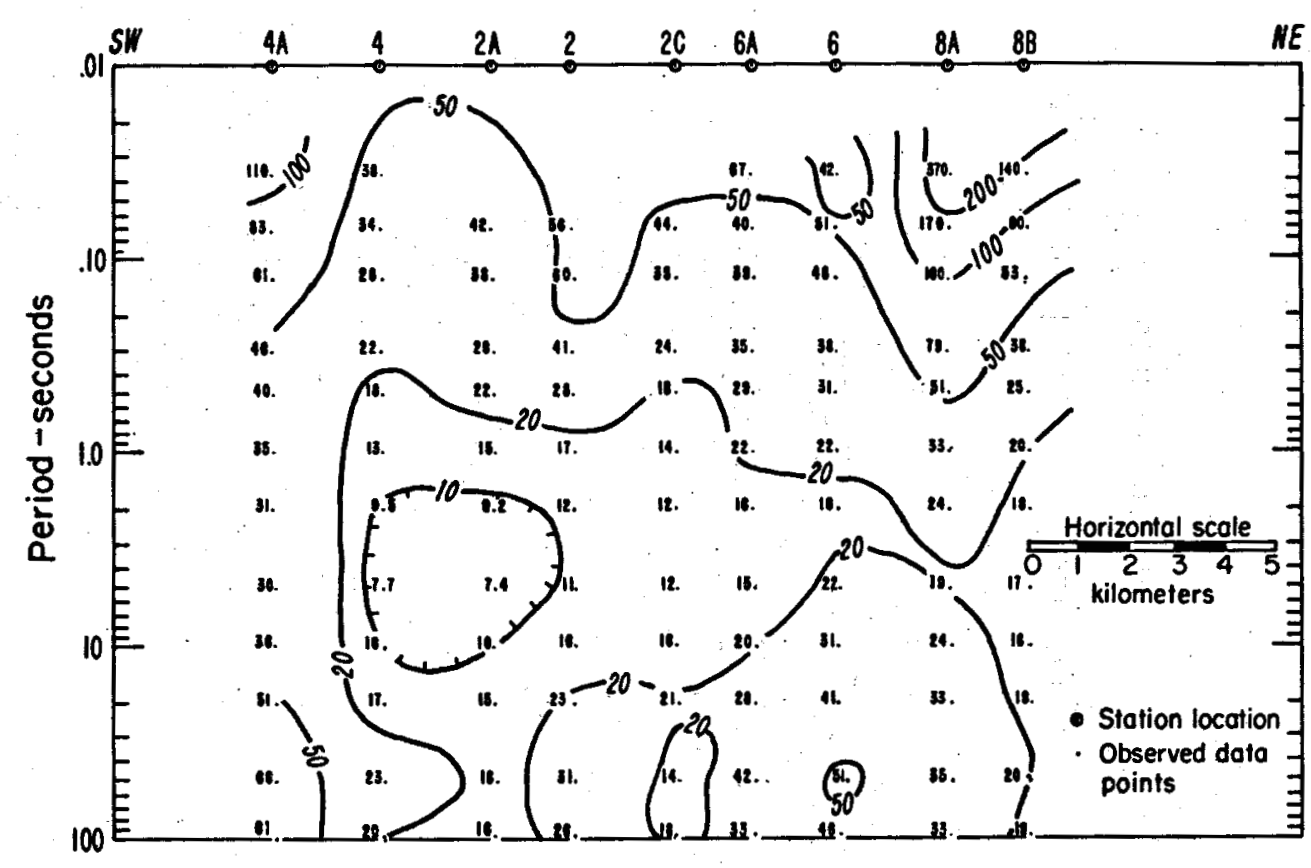

Fig. 17a

$X B L 789-6512$

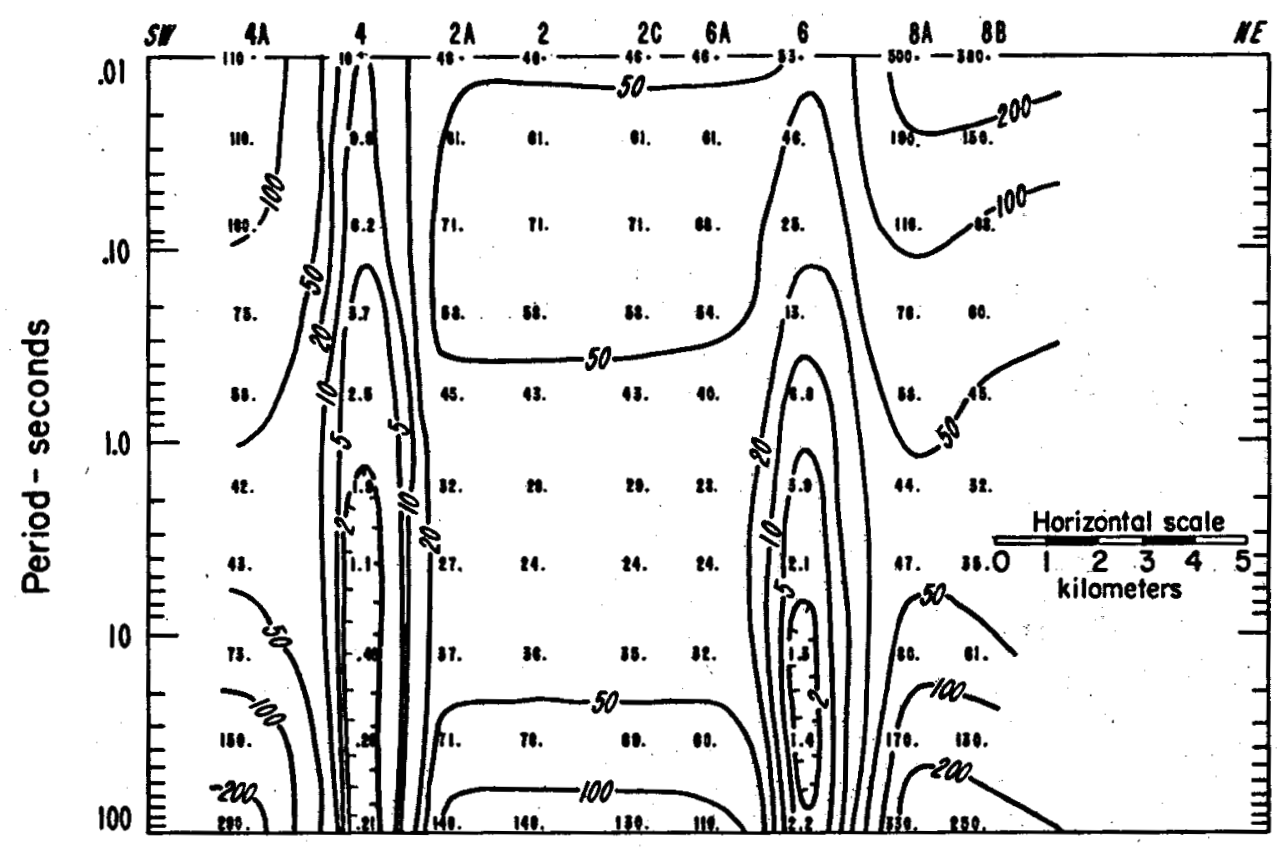

Fig. $17 \mathrm{~b}$

XBL 7810-2090A

Fig. 17. TM mode apparent resistivity pseudo-sections, Line A-A', Swan Lake Valley. 17a. Observed data. 17b. Calculated data for model "OMI". 


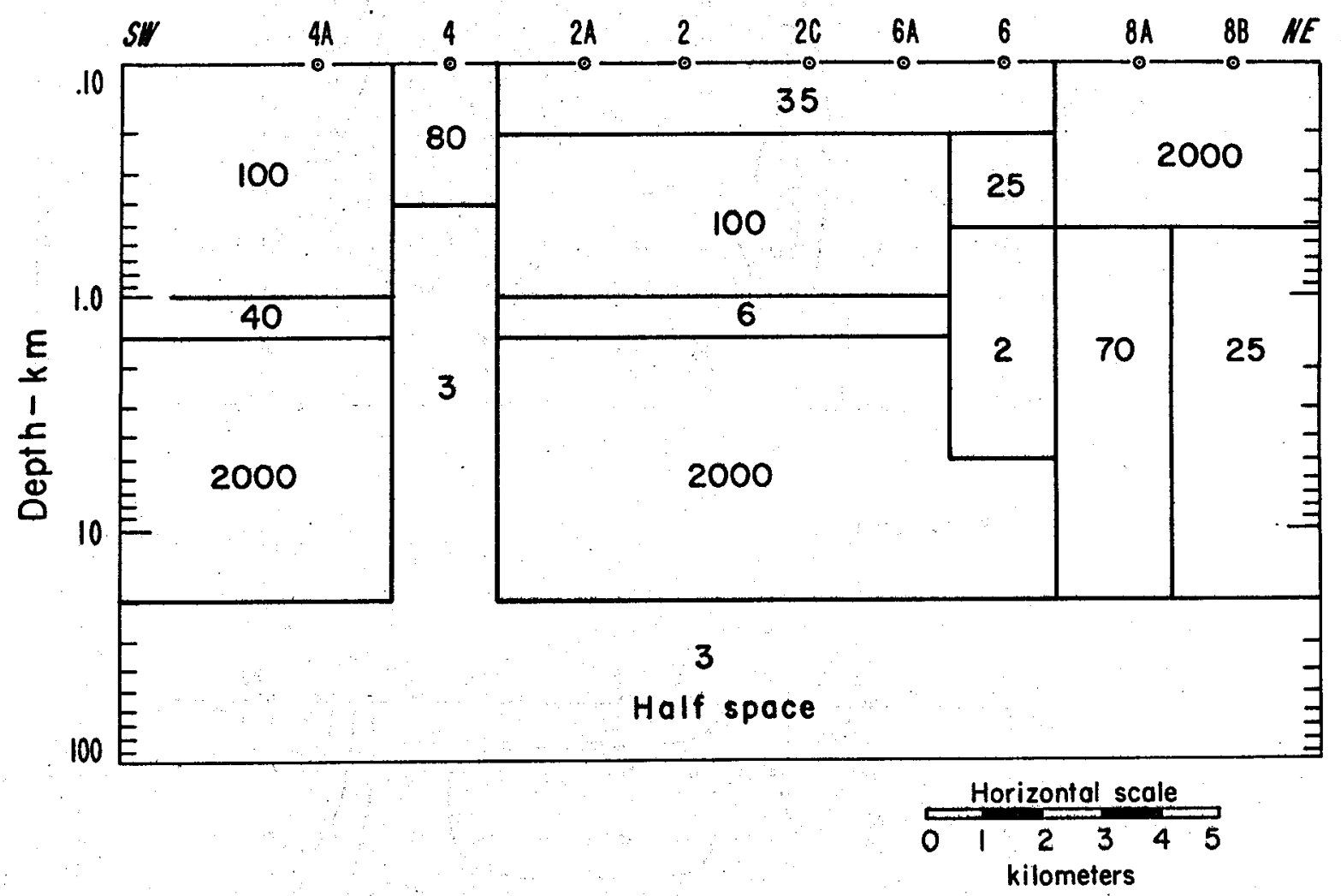

XBL $789-2096$

Fig. 18. Resistivity model "SMI" (values in ohm-meters). 


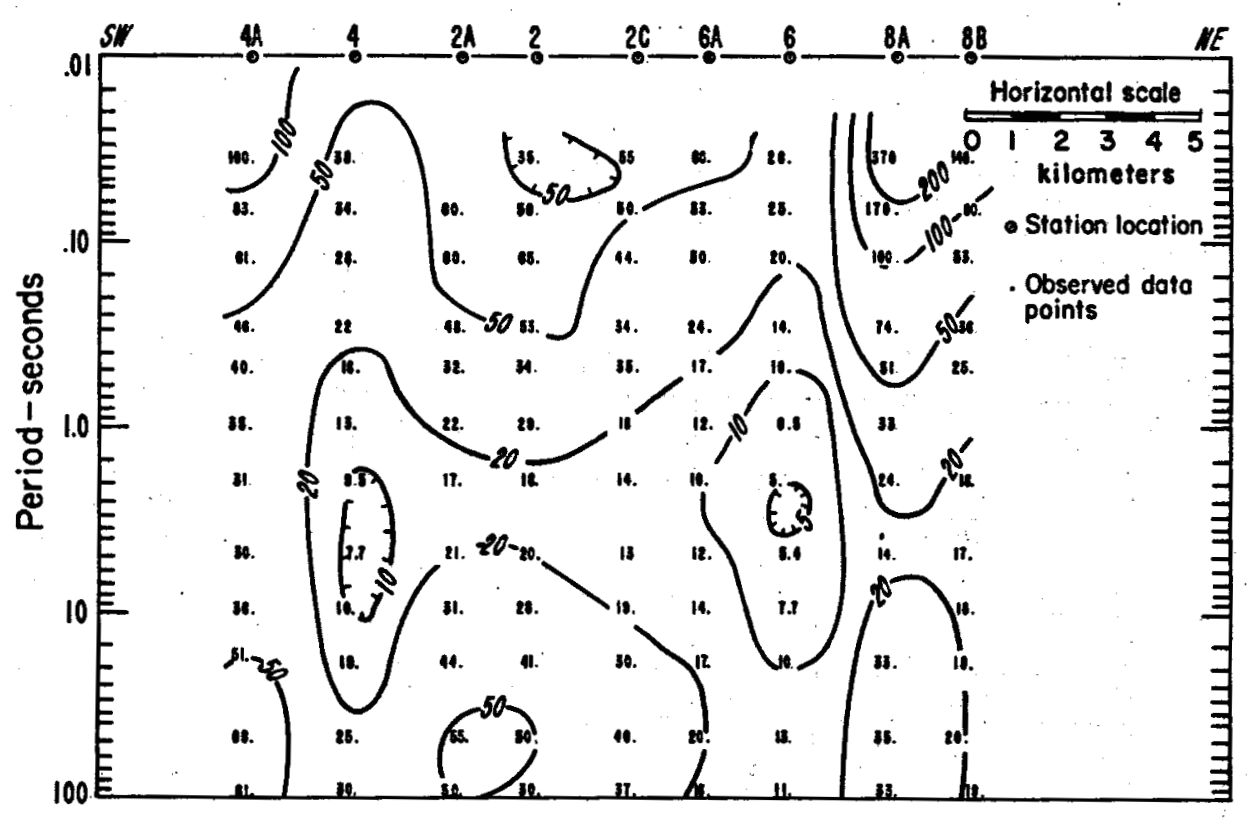

Fig. $19 a$

XEL 789-2085

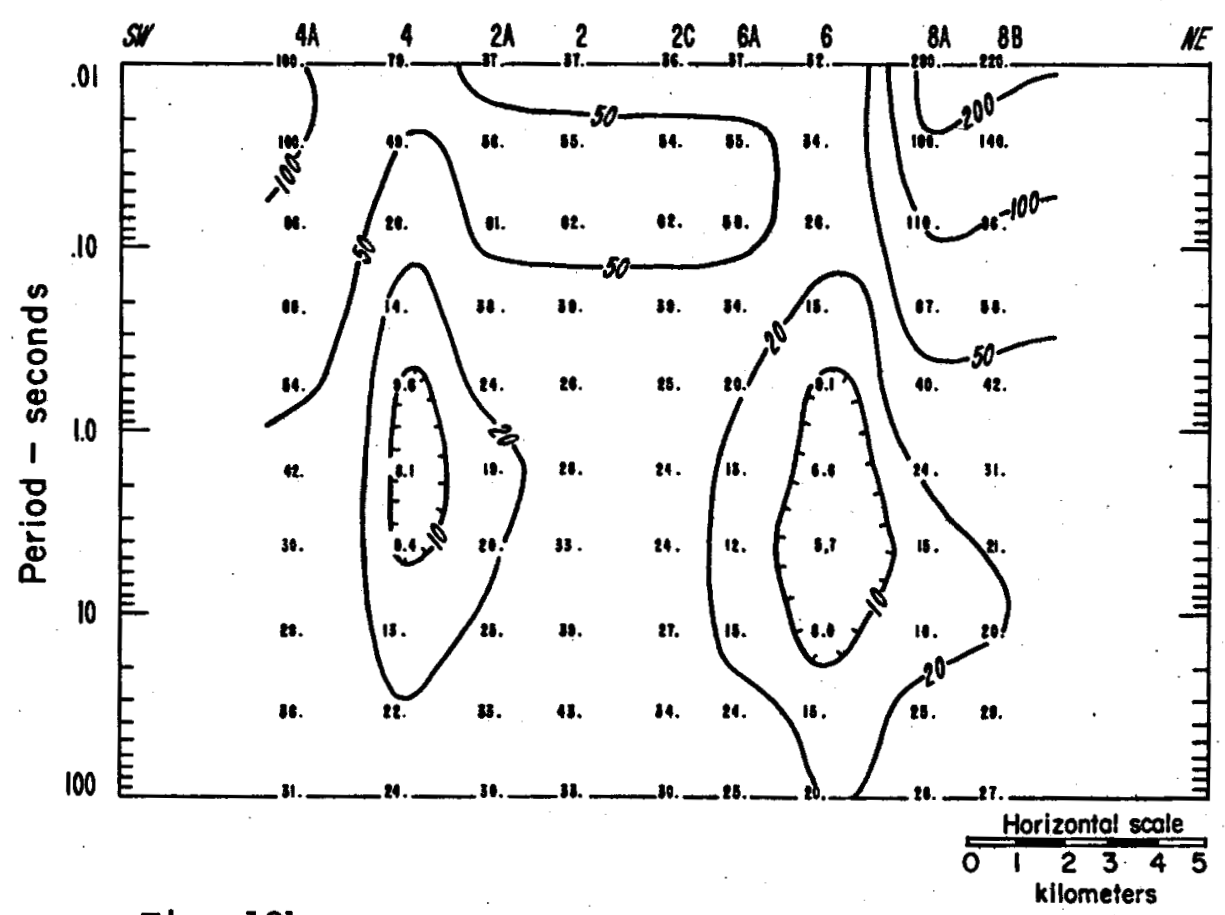

Fig. 19b

XBL 7810-2089A

Fig. 19. TE mode apparent resistivity pseudo-sections, Line A-A', Swan Lake Valley. 19a. Observed data, modes switched at stations $4,8 \mathrm{~A}$ and $8 \mathrm{~B}$.

19b. Calculated values for model "SMI". 


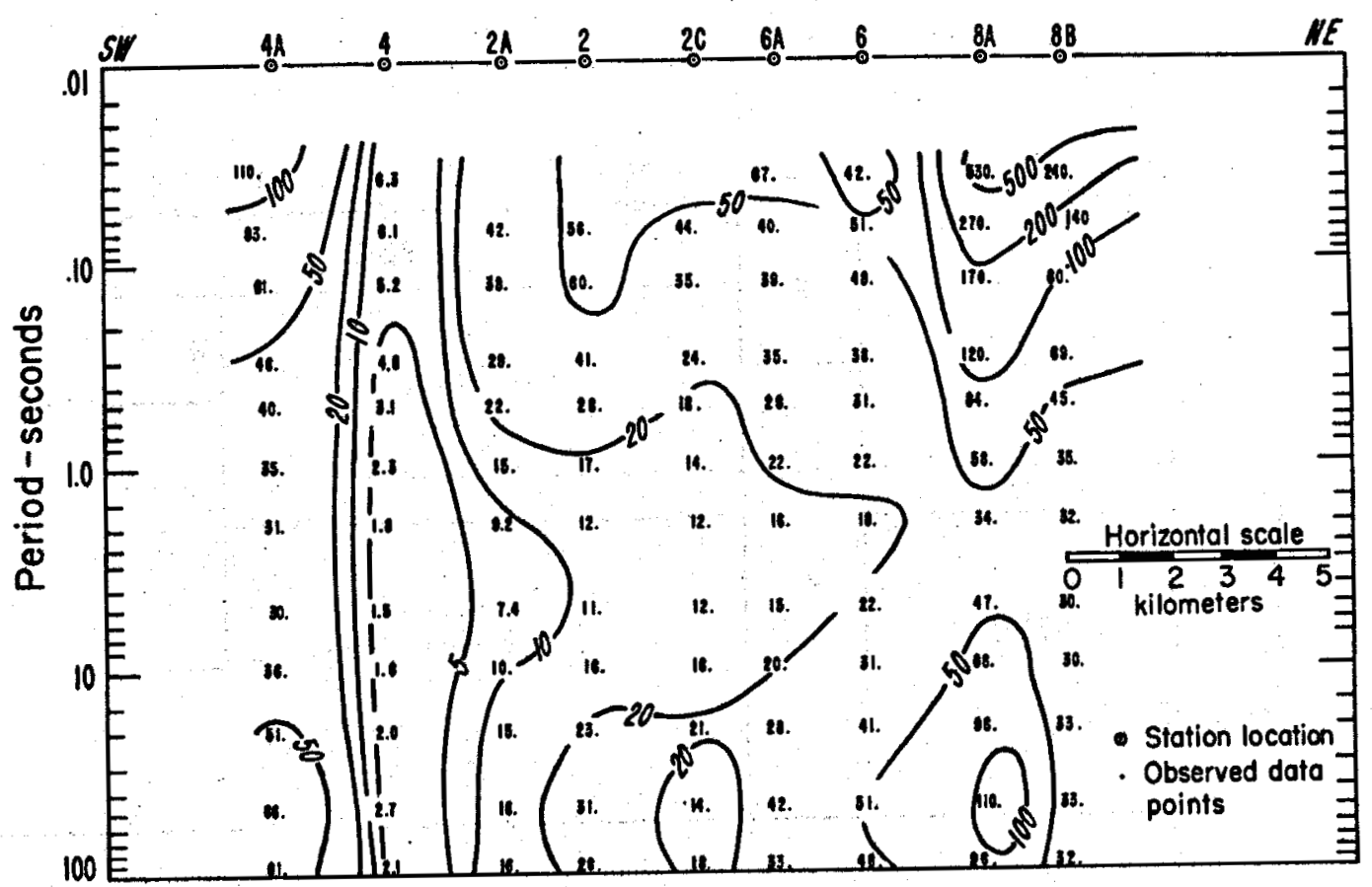

Fig. 20a

XBL 7810-2087

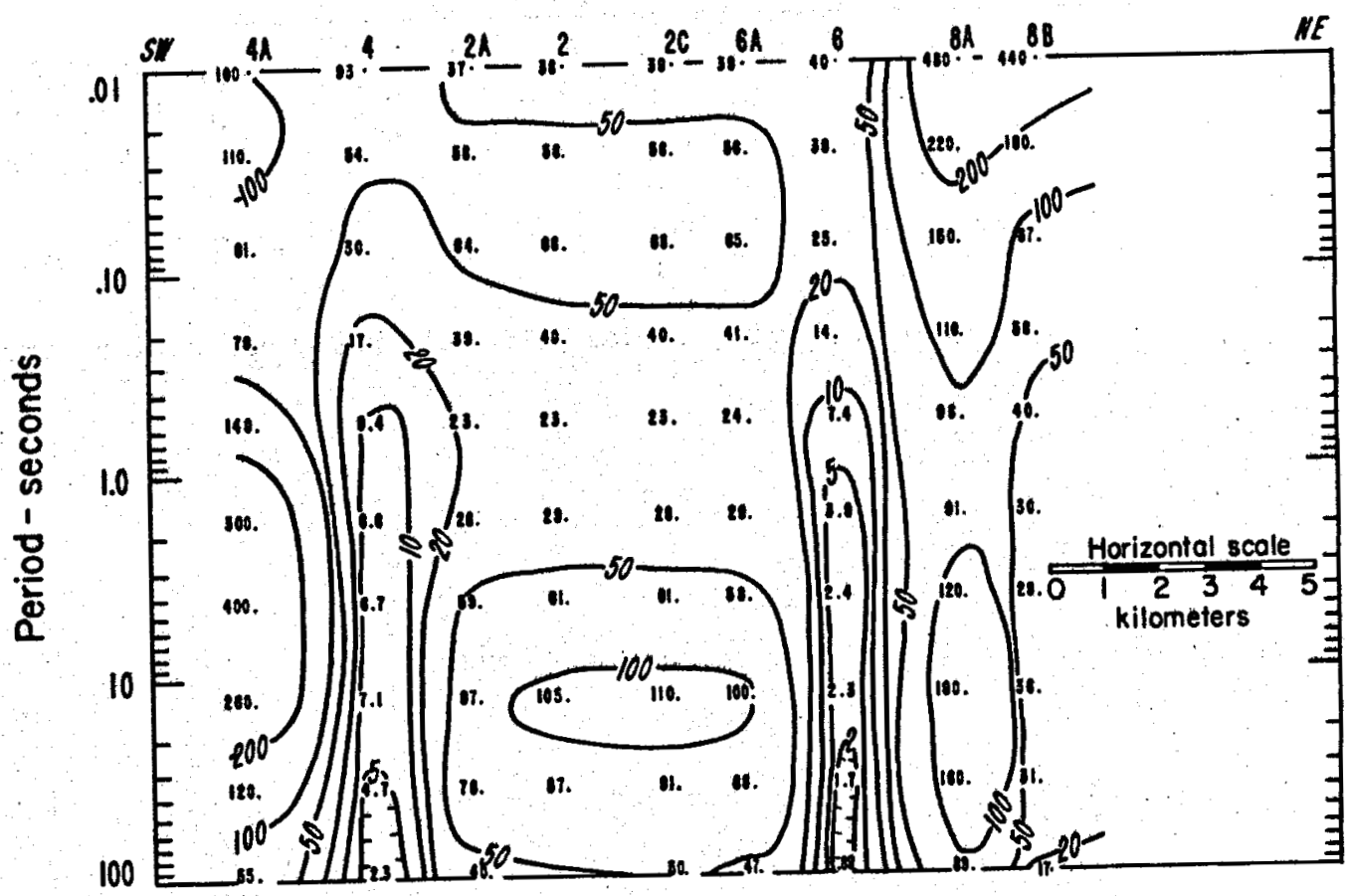

Fig. 20b

XEL 7810-209IA

Fig. 20. TM mode apparent resistivity pseudo-sections, Line $A-A$, Swan Lake Valley. 20a. Observed data, modes switched at stations $4,8 \mathrm{~A}$ and $8 \mathrm{~B}$.

20b. Calculated values for model "SMI". 


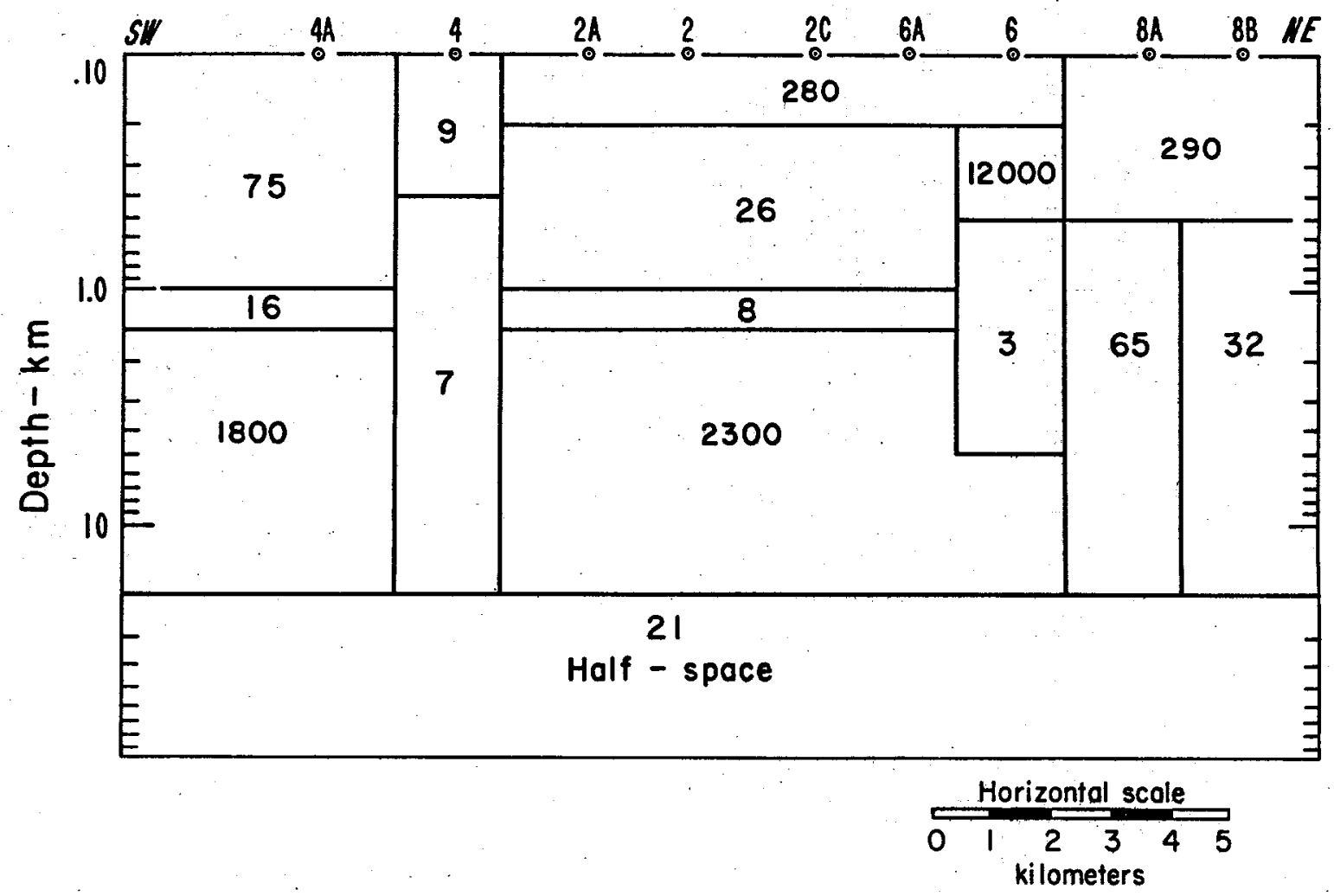

XBL 789-2095

Fig. 21. Resistivity model "ISMID" (values in ohm-meters). 


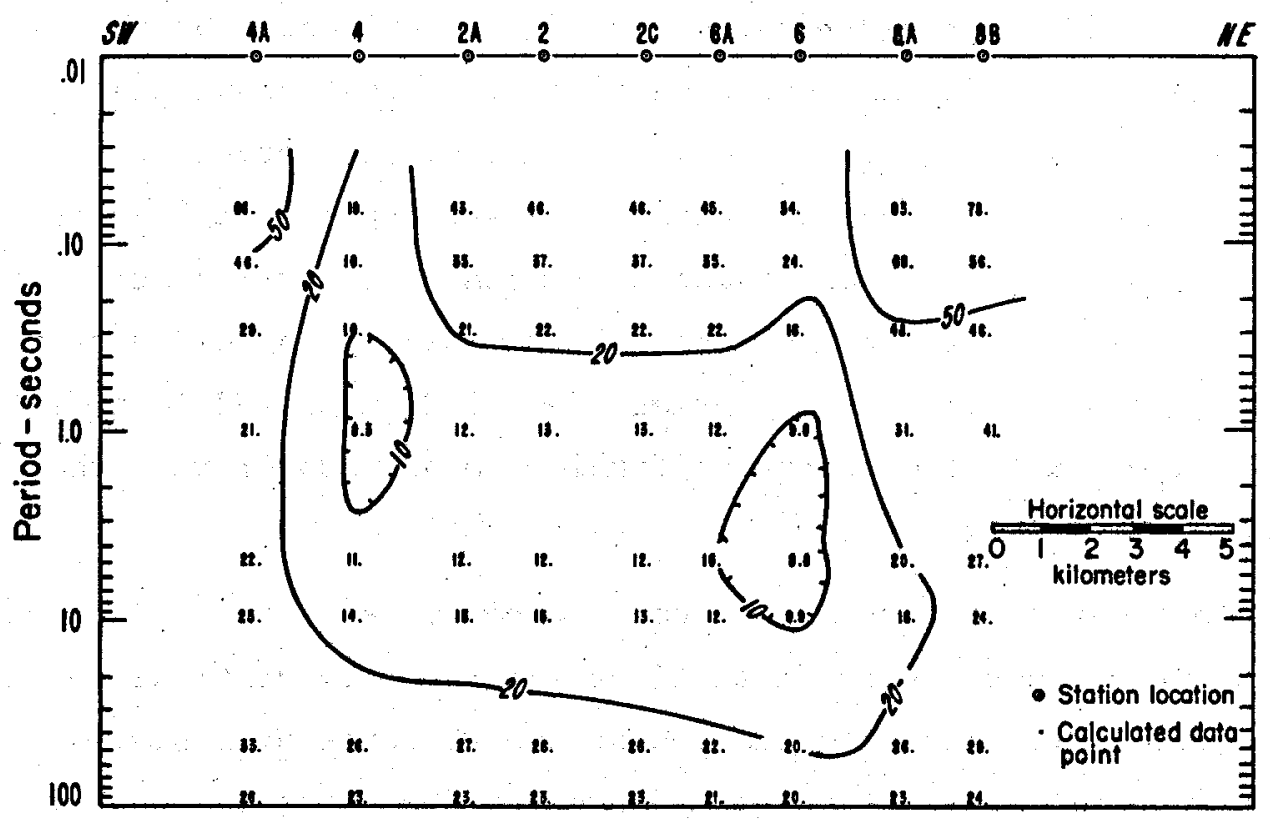

$F+g, 22 a$

XBL 7810-2088

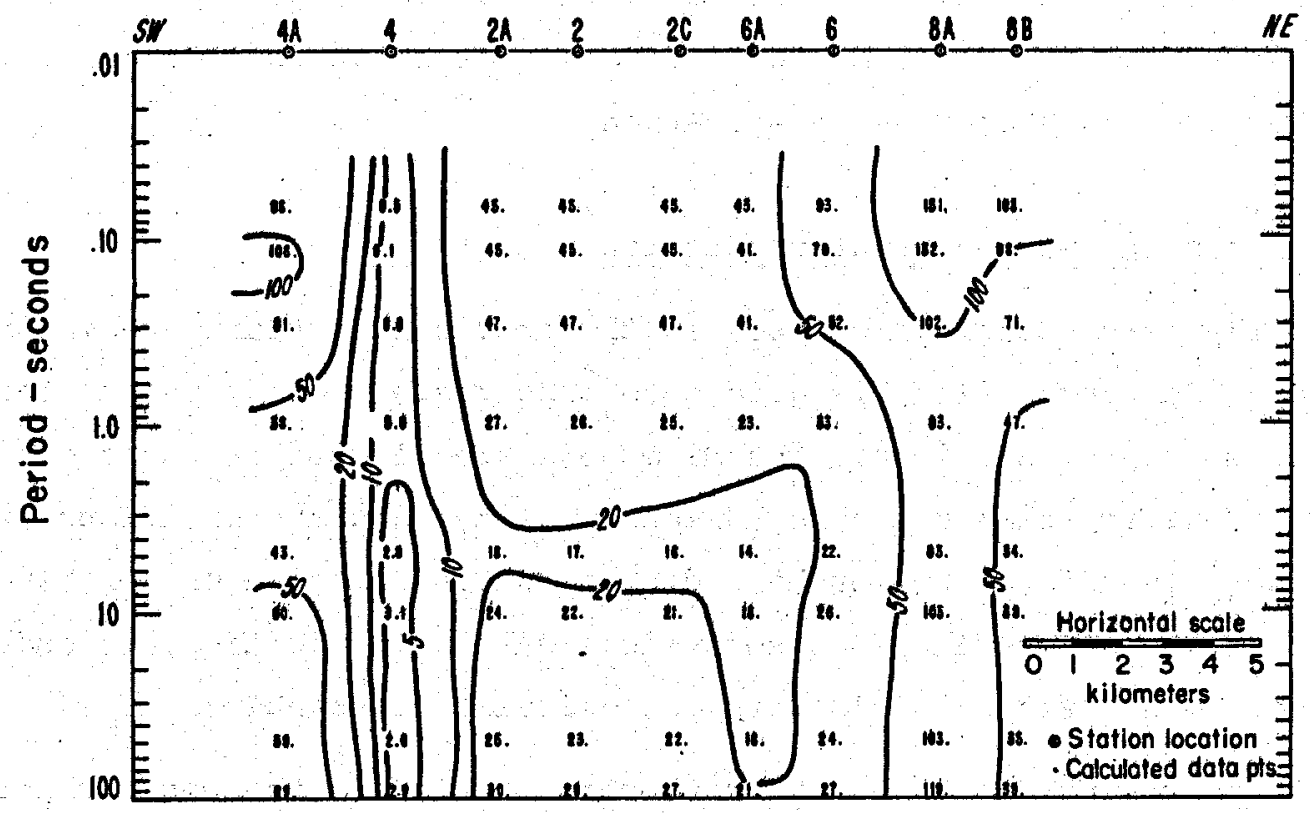

Fig, 22b

XEL 78S-2086A

Fig. 22. Apparent resistivity pseudo-sections calculated for model ISMID, Line A-A', Swan Iake Valley.

22a. TE mode (compare to Fig. 19a).

22b. TM mode (compare to Fig. 20a). 
probably highly three-dimensional. This is evidenced by the difficulty in obtaining two-dimensional pseudo-sections that simultaneously match both the TE and TM observed data. Unfortunately, state-of-the-art three-dimensional modeling routines are still prohibitively expensive to use, so two-dimensional modeling remains the best practical interpretation scheme. However, the results from simple three-dimensional geometries modeled by other workers (e.g., Hohmann and Ting, 1978) can be applied in a qualitative fashion to help understand the situation in Swan Lake Valley.

In general, the third dimension tends to accentuate differences in the TE soundings between stations separated by vertical resistivity boundaries. It also seens to accentuate TE apparent resistivity changes with respect to period caused by layering (horizontal boundaries). This may be the case in Swan Lake Valley, where the observed TE pseudosections (Figures 16a and 19a) show extreme variation of apparent resistivity with respect to both horizontal distance and period. One might also speculate that the observed electrical isotropy at station $4 \mathrm{~A}$ is due to some symmetrical three-dimensional electrical structure, rather than a layered-earth situation.

Synthesis and Geologic Interpretation

The earth models presented in the previous sections are intended to provide rough, flexible guides to subsurface geology rather than accurate representations. The MT models are plagued by questions of mode identification and three-dimensionality, and the solutions are not unique. Therefore; we sought independent confirmation of our findings in the form of overlapping geophysical data. In addition, we endeavored to determine if the models were geologically reasonable.

The roving dipole and MT data sets overlap in the western portion of the Swan Lake Valley area. Therefore, we attempted to fit the roving dipole data with the western portion of our MT model SMI. A few minor adjustments to this model proved sufficient to satisfy the roving dipole data (compare Figures 13 and 18). 
The gravity, aeromagnetic, roving dipole, and MT data sets all suggest a 1 ithologic change at a depth of about 1 kilometer beneath Swan Lake Valley. This may mark the transition from the Yonna Formation to the underlying basalt flows. Overlapping geophysical evidence lends credence to our interpretations, but more detailed exploration work is needed to provide adequate constraint on the model parameters. For the time being, however, we will use model ISMID (Figure 21) as a rough guide to subsurface geology. This model was chosen because it fits the observed TM data better than models SMI and OMI, and we feel that this is a favorable characteristic in this three-dimensional area.

The central portion of Swan Lake Valley is underlain by resistive to moderately conductive material (280 to 26 ohm-meters) to a depth of 1 kilometer. This may represent relatively impermeable lacustrine alluvium overlying Yonna Formation rocks. This is underlain by 500 meters of 8 ohm-meter material - possibly an aquifer in the older basalt unit. Beneath this lies 19 kilometers of electrically resistive (2300 ohm-meters) basement rock, probably consisting of tight basalts or other igneous rock. Finally, at a depth of 20 kilometers we reach conductive, lower crust rocks (21 ohm-meters). A similar interpretation of the electric layers is applicable in the area southwest of Meadow Lake Valley.

Meadow Lake Valley Itself appears as a conductive $(7$ to 9 ohmmeter) dike-like feature about 2 kilometers in width. In the model, this zone merges with the lower crustal rocks at a depth of $20 \mathrm{kilo-}$ meters. However, the zone may not extend so deep in actuality, it is difficult to resolve the "bottom" of a conductive block with the MT method. Regardless of its true depth extent, we interpret the conductive zone as a highly fractured fluid-filled fault zone. 
Beneath the northeastern edge of the Swan Lake Valley lies another conductive block with a resistivity of 3 ohm-meters. In the model we show a lower boundary for the conductor, but again this feature is not well resolved. The conductor may represent a complex, sheared fault zone similar to the one on the southwestern side of the valley. Alternatively, we might be seeing the effect of alteration and hydrothermal circulation along the boundary fault. Directly above the conductor lies a highly resistive block with a resistivity of 12,000 ohm-meters. The true resistivity of the block may not be that high, but it is reasonable to infer an impermeable, possibly mineralized cap rock overlying the conductor.

At the extreme northeastern end of the model, Swan Lake Rim appears as a resistive (290 ohm-meter) basalt block, fault-displaced upward from similar rock underlying the valley.

\section{The Geothermal Target}

The data suggest that Swan Lake Valley is bordered by two conductive zones which are connected via a conductive layer. The conductive border zones occur beneath Meadow Lake Valley and beneath Swan Lake. The conductive layer lies 1 to 1.5 kilometers below the valley floor.

These zones may be permeable regions saturated with geothermal fluids which have ascended along fault zones. At this stage several follow-up exploration techniques could be suggested to help determine whether thermal anomalies exist and to help define the conductive "layer" at depth. Shallow temperature gradient drilling along northeast-trending lines from Meadow Lake Valley to the Swan Lake Rim, detailed resistivity (dipole-dipole or Schlumberger soundings) across the center of Swan Lake valley, and more detailed gravity surveys would help to pinpoint a drill target in the area. In addition, the waters from Holcomb Spring should be chemically analyzed to estimate equilibration temperatures. The depth to conductive lower-crust indicated by the MT data is rather shallow $(20 \mathrm{~km})$. This phenomenon has been reported in several geothermal areas (e.g., stanley et al., 1977). 
Most of our work in the Swan Lake Valley area has focused on Line $A-A^{\prime}$. There are, however, other areas of interest which we plan to study with the available data. These include:

1. An area south of Moyina Hill which has MT apparent resistivities measuring less than 1.0 ohm-meters (Geonomics, 1977).

2. A small roving dipole low apparent resistivity zone located west of Meadow Lake Valley (Group Seven, 1972).

3. The eastern and southeastern portion of swan lake Valley, which has low MT apparent resistivities and may be underlain by an elevated conductive lower crust (Geonomics, 1977).

KLAMATH HILLS AREA

Topography and General Geology

Located 13 to 26 kilometers south of Klamath Falls, the klamath Hills rise about 300 meters from the surrounding flatlands (Figure 23). They stretch northwest-southeast for a total length of about $18 \mathrm{kilo-}$ meters, attaining a maximum width of almost 5 kilometers. To the southwest lies Lower Klamath Lake, which has been completely drained and reclaimed for farmland. Spring Lake Valley and the valley of the Lost River are located northeast of the Hills. We will refer to this area as the Lost River-spring Iake Valley. Further northeast, stukel Mountain stands almost 800 meters above these valleys.

The structure here is typical of the Basin and Range geomorphic province and the Klamath Hills are essentially a horst. Peterson and McIntyre (1970) mapped Yonna Formation rocks and basalt flows in the Hills, with quaternary alluvium and lacustrine sediments covering the valleys (Figure 24).

The area is classified as a KGRA based on the presence of several warm and hot wells, including two wells with temperatures exceeding 


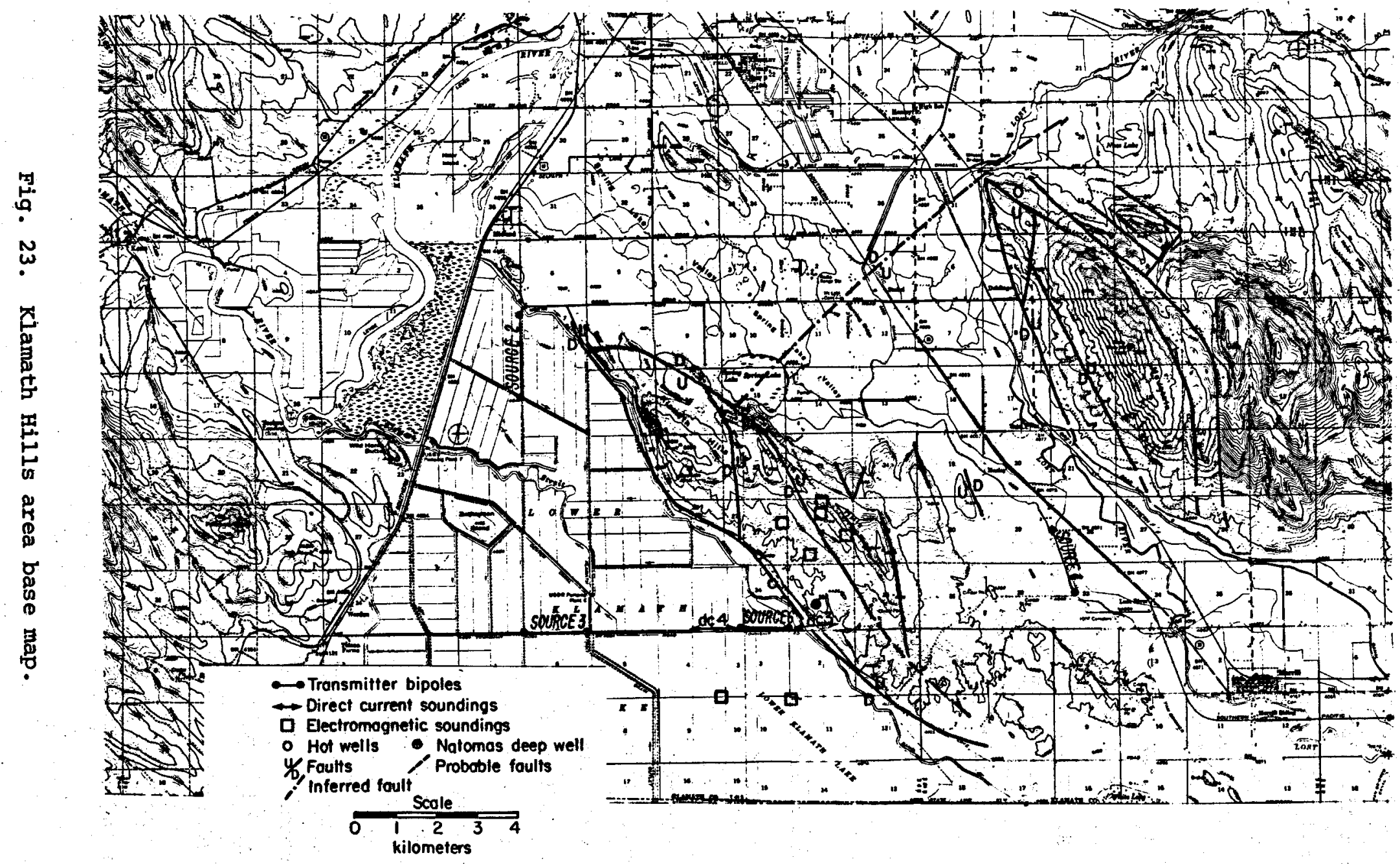

XBL7810-6517 


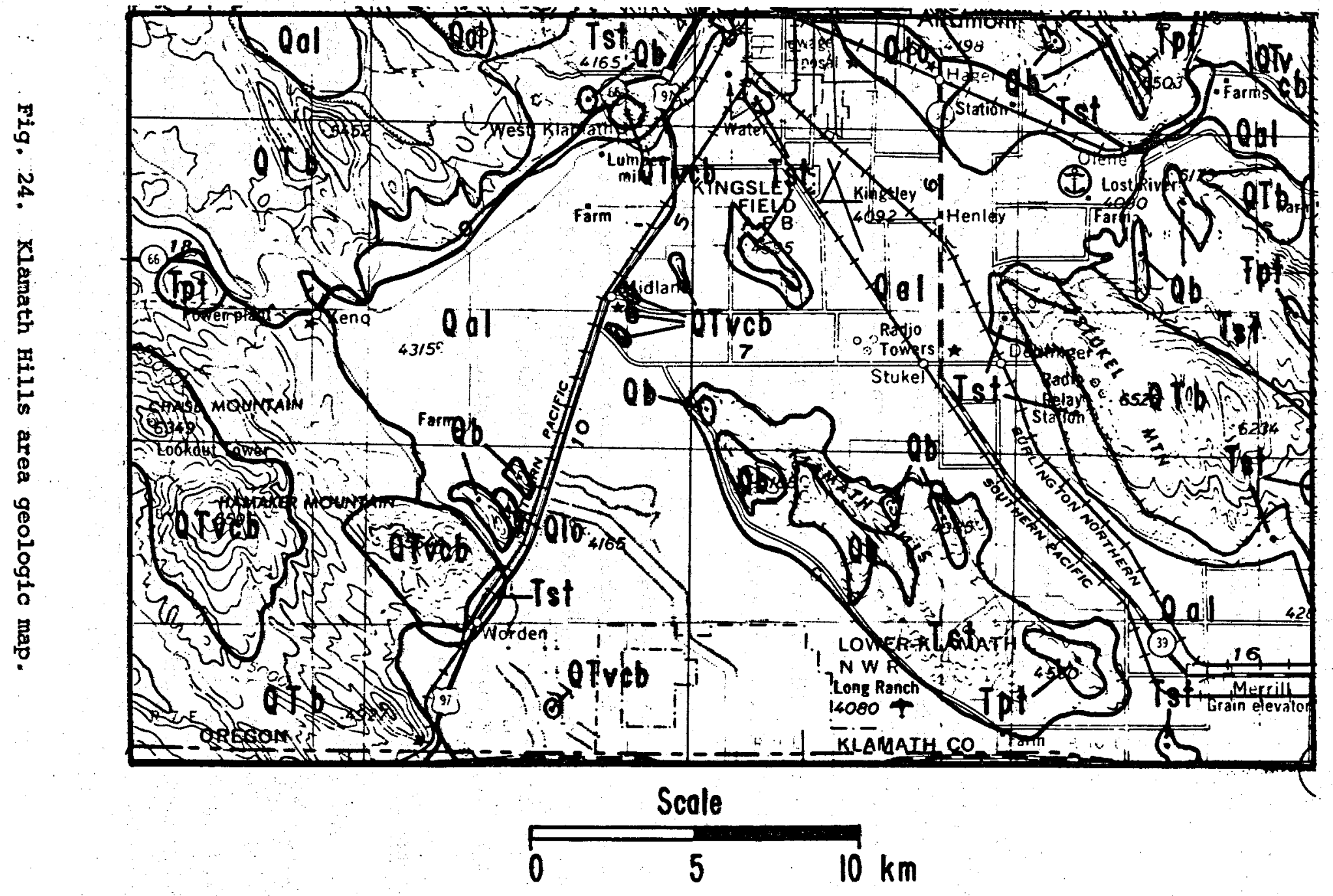

XBL 7812-2203A 
$90^{\circ} \mathrm{C}$. These two are located in sections 27 and $34, T 40 S, R 9 E$. We will refer to these as the Hot Wells. In addition, several warm wells, with temperatures from $20^{\circ} \mathrm{C}$ to $50^{\circ} \mathrm{C}$, exist along the southwest edge of the Hills (Sammel, 1976). Other warm wells are located near Miller Hill and near the northwestern tip of stukel Mountain.

\section{Gravity Survey}

Van Deusen (1978) occupied about 25 gravity stations in this area as part of his regional study. As in Swan Lake Valley, we have dealt only with his complete Bouguer reduction, Bouguer density $2.67 \mathrm{~g} / \mathrm{cm}^{3}$. (Figure 25). Van Deusen's model for profile A-A' indicates a 1 kilometer thickness of valley fill overlying basement. His model for profile D-D' predicts only 100 meters of valley fill. These estimates were made assuming a density contrast of $1.0 \mathrm{~g} / \mathrm{cm}^{3}$ and thus both thickness estimates should be considered minimum values. True fill thicknesses may be 2 or 3 times greater.

The gravity contours form a saddle between stukel Mountain and the Klamath Hills, centered near the town of Hosley. This may be caused by a raised northeast-trending basement ridge between the two mountains. The associated northeast-trending gradient running in a line between olene Gap, Stukel and Worden, passing through the Klamath Hills, is the Olene Gap lineament mentioned earlier.

\section{Microearthquake Study}

Microgeophysics Corporation conducted a ten-day microseismic survey with an array centered on the Klamath Hills (Natomas Company, 1978). Eleven high-frequency $(5-30 \mathrm{~Hz})$ instruments were operated with amplifications ranging from $5 \times 10^{5}$ to $2 \times 10^{6}$. The array was designed to record earthquakes down to magnitude -0.5 , but no events were recorded during the ten-day span. 


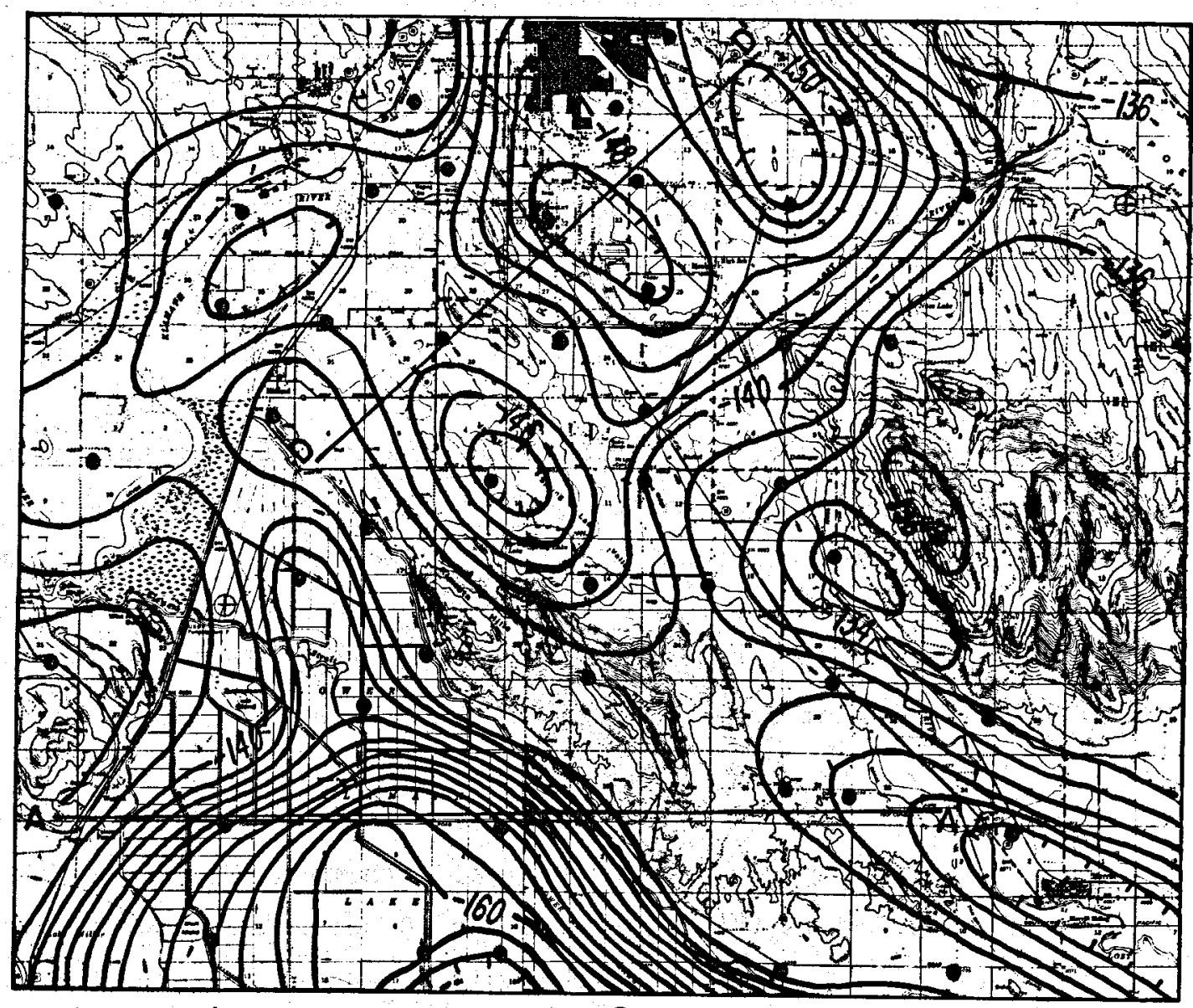

- Gravify station

Contour interval - 2.0 milligals

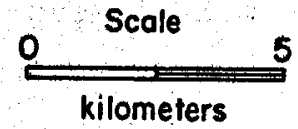

$X B L 781 Q-6520$

Fig. 25. Complete Bouguer gravity map, Klamath Hills area (after van Deusen, 1978). 
The lack of seismic activity is somewhat surprising in view of the historical seismicity (Couch and Lowell, 1971). The record of felt earthquakes does not indicate many events, but the area is definitely seismically active. This is also borne out by abundant field evidence of geologically recent fault displacements. We therefore conclude that the study was conducted during an unusually quiet time. A successful study would have yielded information about the locations and earthquake mechanisms of active faults in the area, thus helping to delineate possible target areas.

\section{Audio-Magnetotelluric Survey}

Senterfit and Bedinger (1975) made scaler audio-magnetotelluric (AMT) measurements at 23 stations with both north-south and east-west telluric dipole orientations. Their U.S. Geological survey system was tuned to 12 pre-selected narrow frequency bands between $7.5 \mathrm{~Hz}$ and $18.6 \mathrm{kHz}$. The brief open-file report contains no interpretation, only a tabulation of apparent resistivity values. At each station and frequency, 1 to 10 repeat measurements were made, and the average apparent resistivity was tabulated along with the standard deviation. Data reproducibility varies, with most of the standard deviations falling in the range of 10 to 30 percent of the observed apparent resistivities. Significant discrepancies between the northsouth and east-west apparent resistivities suggest that the geology is multidimensional and that a tensor survey is necessary for realistic interpretation. A further limitation of the AMT survey is the rather shallow depth of exploration associated with these frequencies and resistivities. Even at the lowest frequency, $7.5 \mathrm{~Hz}$, skin depths are on the order of 500 meters.

Twenty of the 23 AMT stations were located in the Klamath Hills area, mostly in the Lost River - Spring Lake Valley and in the Klamath Hills. We plotted and contoured the north-south and east-west apparent resistivities at $7.5 \mathrm{~Hz}, 27 \mathrm{~Hz}$ and $6.7 \mathrm{kHz}$, but because of general similarities between them, only the contour map for the north-south telluric 


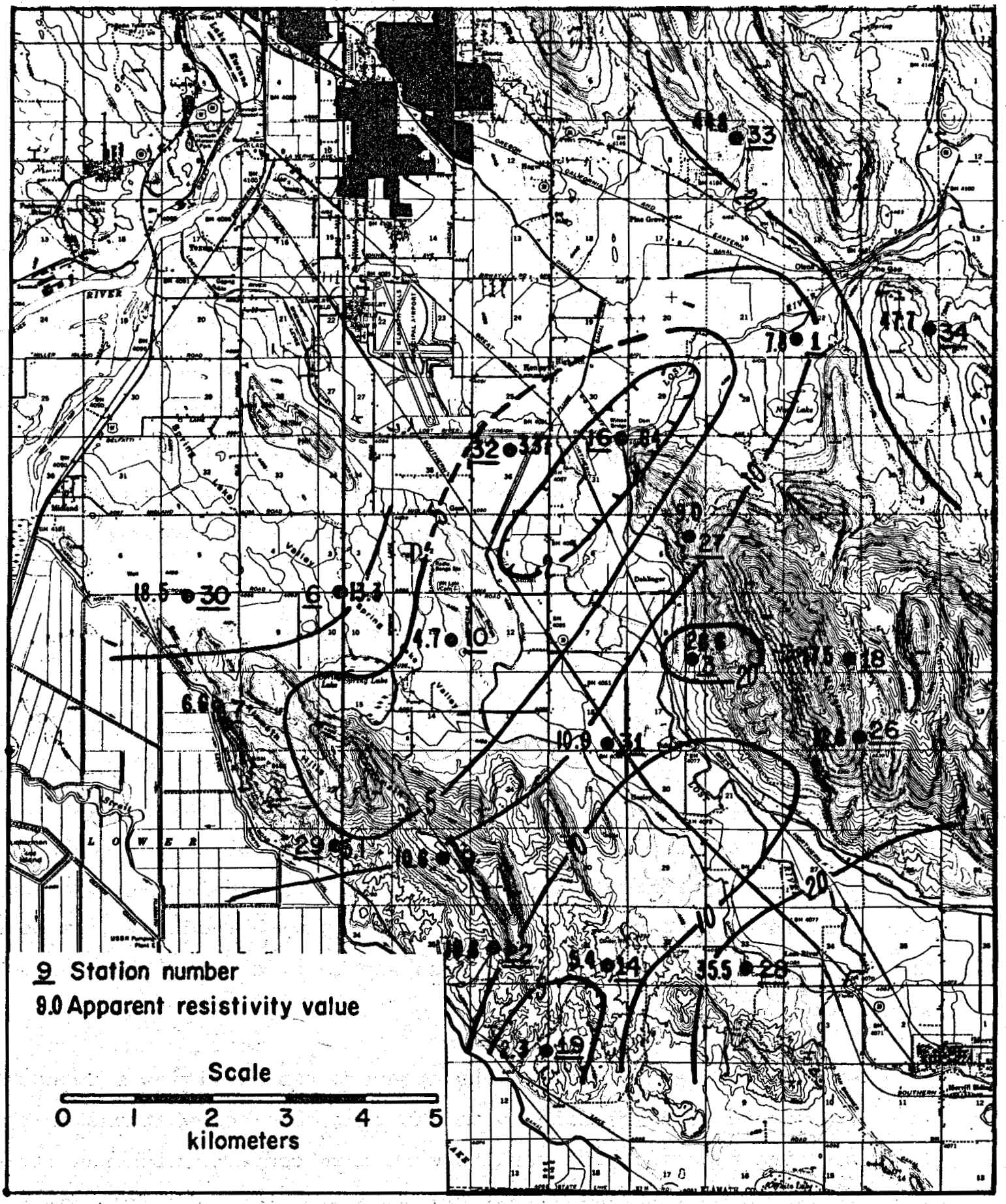

XBL 7810-6527

Fig. 26. Audio-magnetotelluric apparent resistivities, north-south telluric orientation at $7.5 \mathrm{~Hz}$, , Klamath Hills area (data from senterfit and Bedinger, 1976). 
polarization at $7.5 \mathrm{~Hz}$ is shown here (Figure 26). Perhaps the most arresting feature on the map is the general northeasterly trend of the anomalies, particularly the low centered on station 16. This trend is perpendicular to the regional northwest geological trend, and the low resistivity zone suggestive of a fault, conforms closely with the olene Gap gravity lineament. The apparent resistivity low at the north end of Stukel Mountain appears at all frequencies plotted and for both directions of electric field.

Southeast of this low is a high apparent resistivity zone followed by another conductive zone. These anomalies are also northeast trending, and show up, at least in a general way, at all three frequencies. The high resistivity zone is centered on the town of Hosley, and its contours resemble those of the gravity high located in the same area. This reinforces the notion of a buried basement ridge crossing the valley beneath Hosley.

Roving Dipole Resistivity Survey

Group Seven Incorporated (1972) conducted roving dipole resistivity surveys over a 250 square kilometer area including Lower Klamath Lake, the Klamath Hills, and the Lost River-Spring Lake Valley. Figure 23 shows the locations of the four bipole sources. Potential dipoles were placed at approximately 420 stations and apparent resistivities were calculated at each station. At stations with readings from more than one bipole source, the calculated apparent resistivities were averaged.

We replotted and contoured the apparent resistivities from each source separately, disclosing anomalies that were somewhat masked by the averaging process. The results were then compared with theoretical values calculated for two-dimensional models. Figures 27-30 show the separated apparent resistivity maps.

We used program RESIS2D (Dey, 1976) to generate apparent resistivity maps for our models. A trial-and-error process led to the two-dimensional models 62D and 32D shown in Figures 31 and 32 for Sources 6 and 3 , 


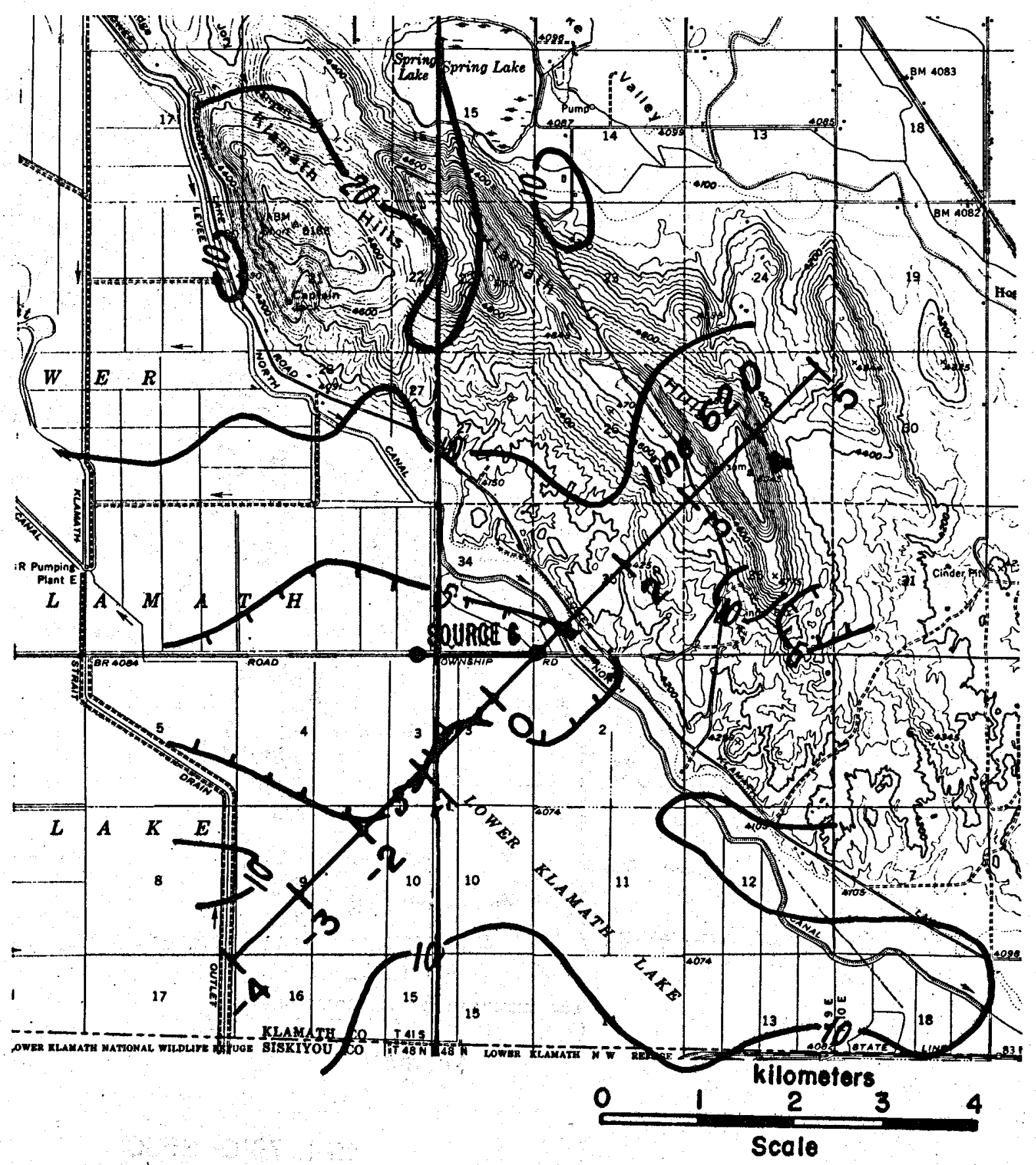

XBL7810-6524

Fig. 27. Roving dipole apparent resistivity from Source 6, Klamath Hills area. 


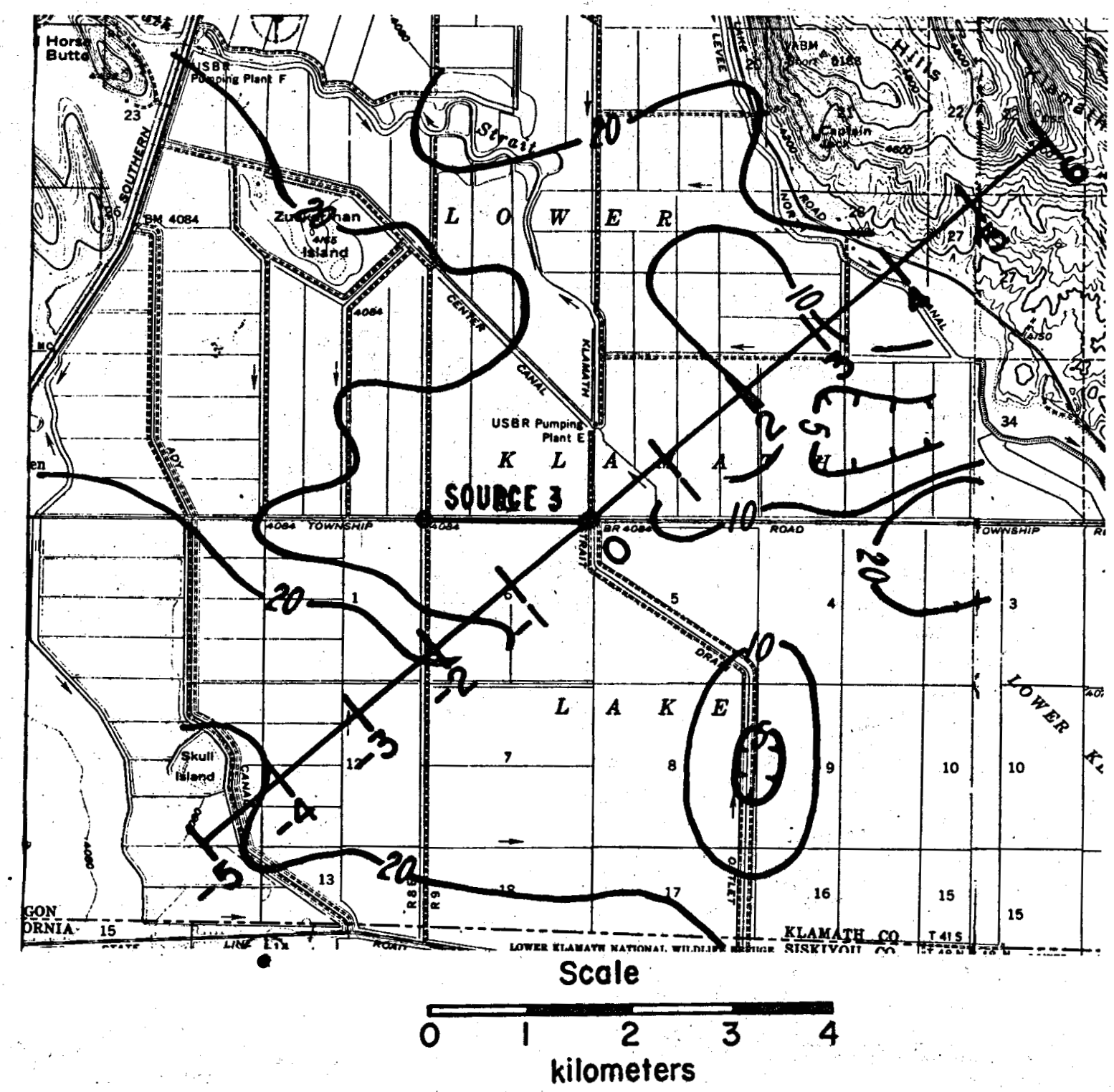

XBL $7810-6530$

Fig. 28. Roving dipole apparent resistivity from source 3, Klamath Hills area. 


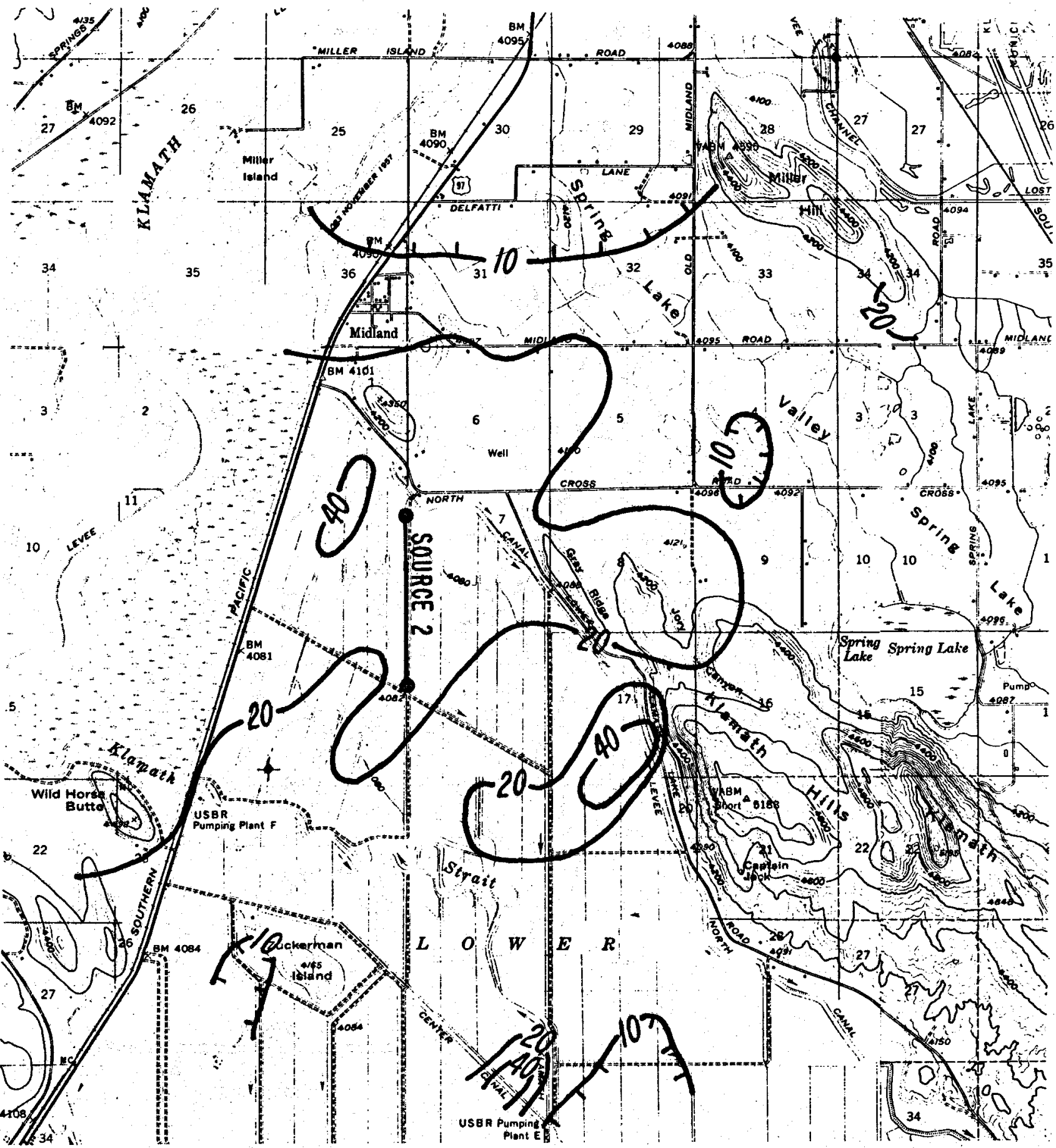

Scale

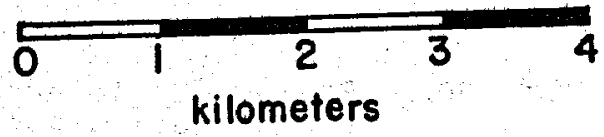

XBL 7810-6526

Fig. 29. Roving dipole apparent resistivity from Source 2, Klamath Hills area. 


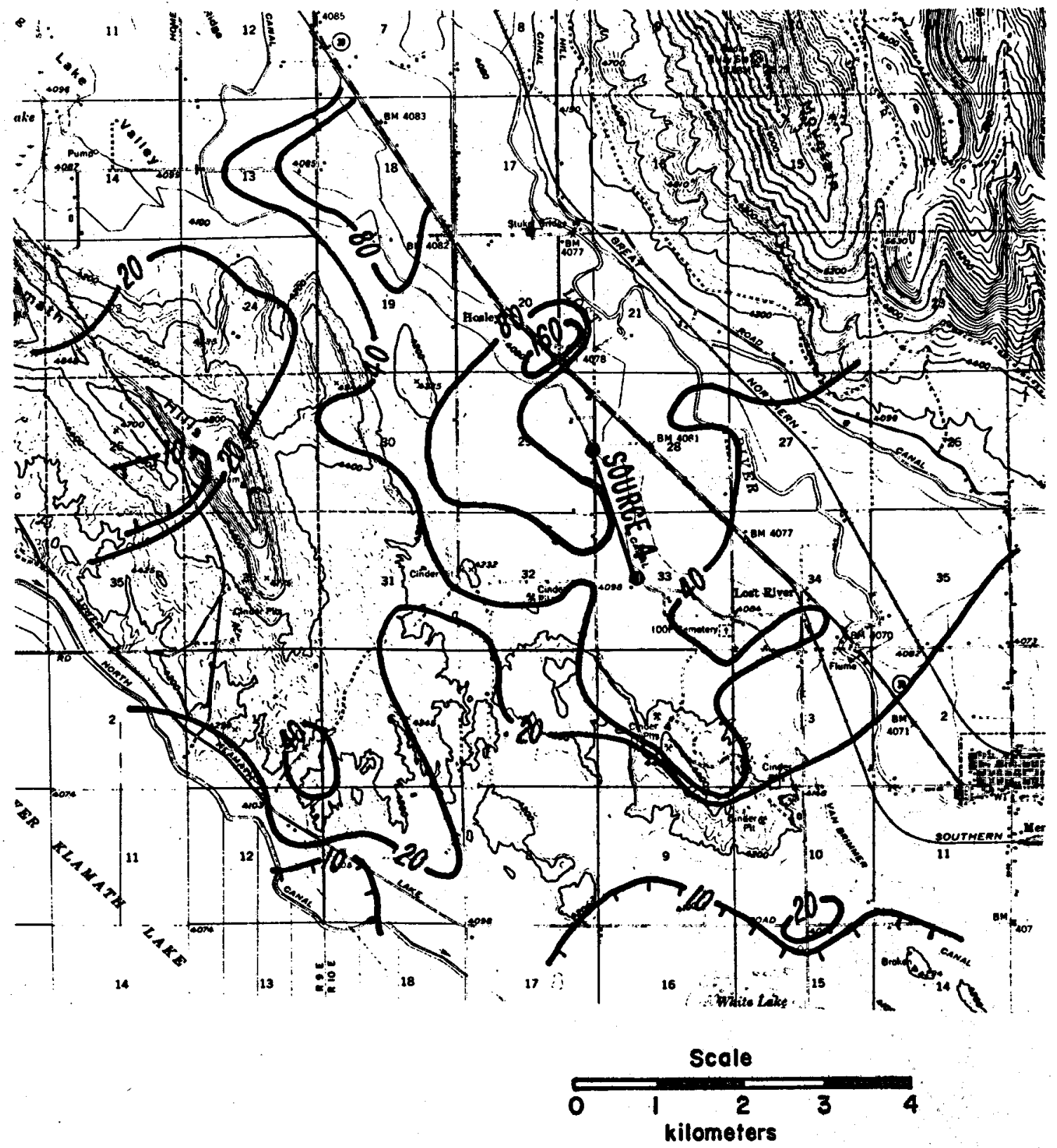

XBL7810-6525

Fig. 30. Roving dipole apparent resistivity from source 4, Klamath Hills area. 


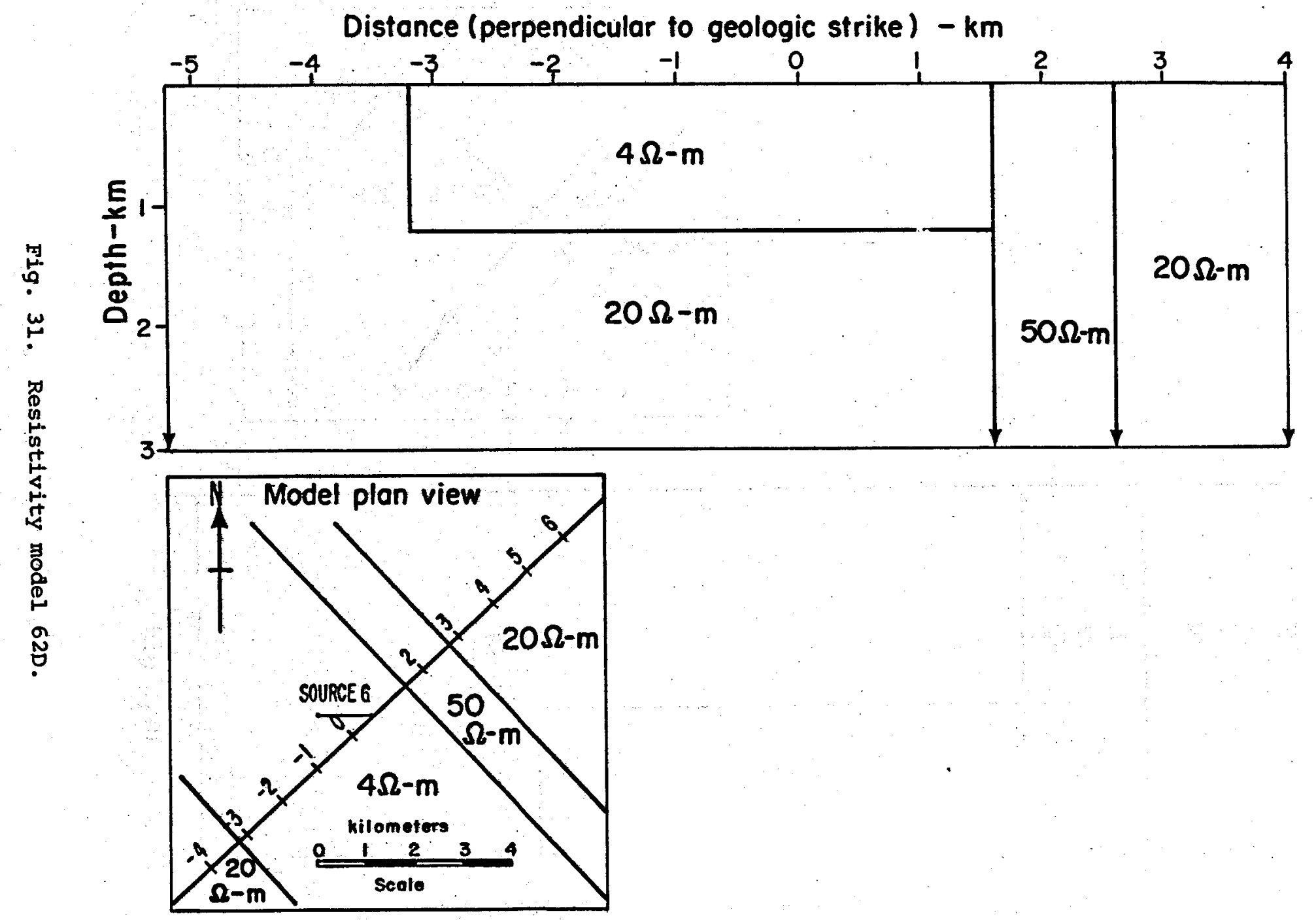



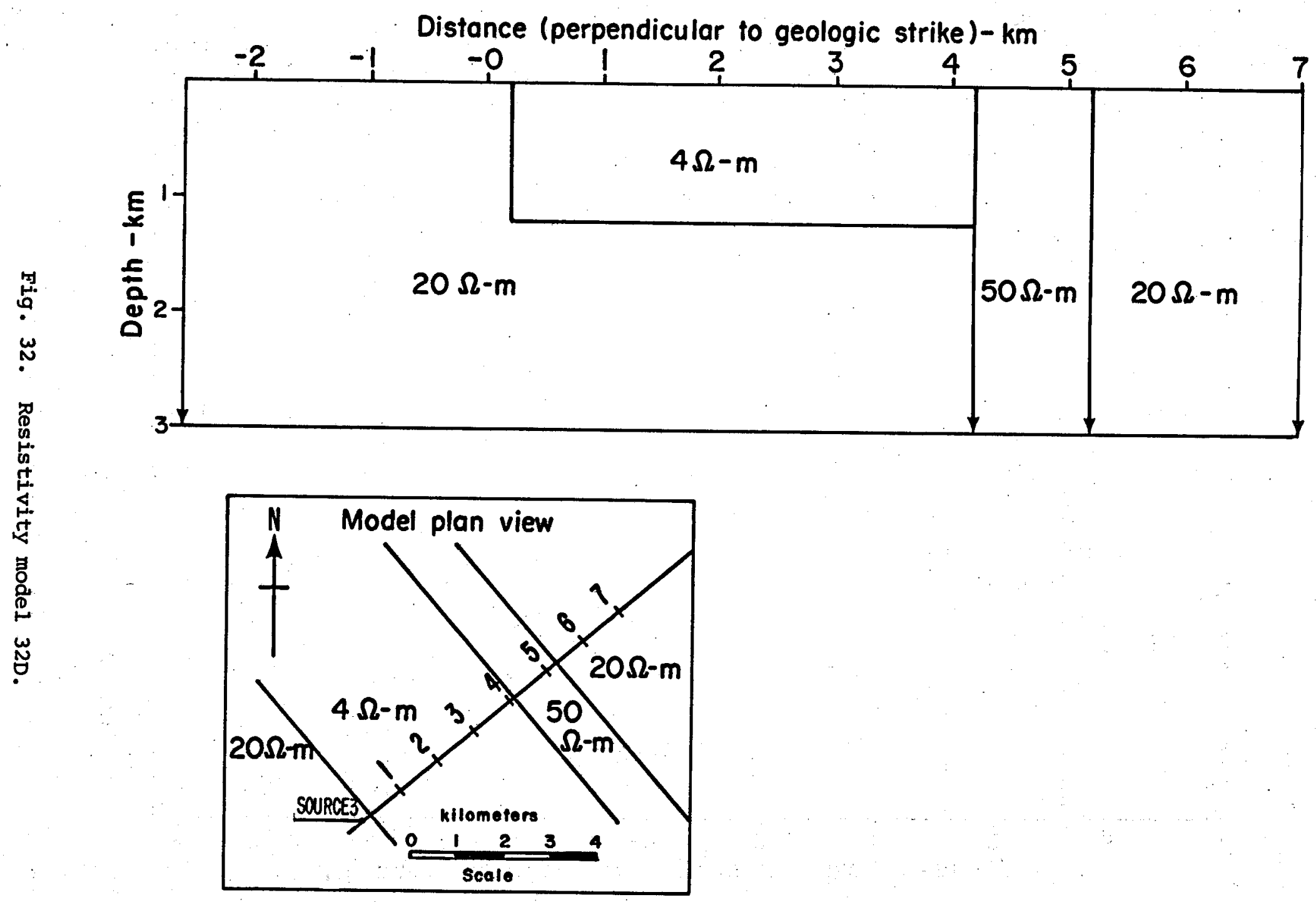

XBL 7810-6523 
respectively. The models are nearly identical. Both include a resistive dike-like body at the edge of the Klamath Hills, and a conductive surface block stretching southwest from the Hills. Figures 33 and 34 show the fits of the calculated maps superimposed on the observed data. These are very general fits, The observed data are probably strongly influenced by local surface inhomogeneities, making a closer fit difficult to achieve. Nevertheless, the relationships among these models and their fits do provide insight into the electrical and geological structure.

The conductive zone in model $32 \mathrm{D}$ is 0.75 kilometer narrower than its counterpart in model 62D. This indicates that the zone is not infinitely long along strike, but is truncated somewhere to the northwest. The poorer fit of model $32 \mathrm{D}$ may be caused by the closer proximity of Source 3 to the truncation. The observed apparent resistivities northwest of the profile line are substantially higher than those to the southeast.

The data from Source 2 (Figure 29) appear to be consistent with these models, but the conductive zone 1s located near the southeastern edge of the area covered, rendering this correlation somewhat marginal.

Source 4 (Figure 30) covers the Lost River-Spring Lake Valley and the Klamath Hills. The transmitting bipole was aligned in northwesterly direction. The apparent resistivities around Hosley are quite high, while those in the Hills cover a broad.range of values but are, in general, lower. The values in the valley farther away from Hosley are also lower. This, again, may be related to a shallow northeasttrending basement ridge,

The data from source 4 near the southwestern edge of the Klamath Hills are also consistent with Models 62D and 32D. There are some high values near the edge of the Hills, corresponding to the resistive dike-like feature in the models. The few readings from source 4 in Lower Klamath Iake are lower than those in the Hills. Again, this is marginal data and these correlations are rather weak. 


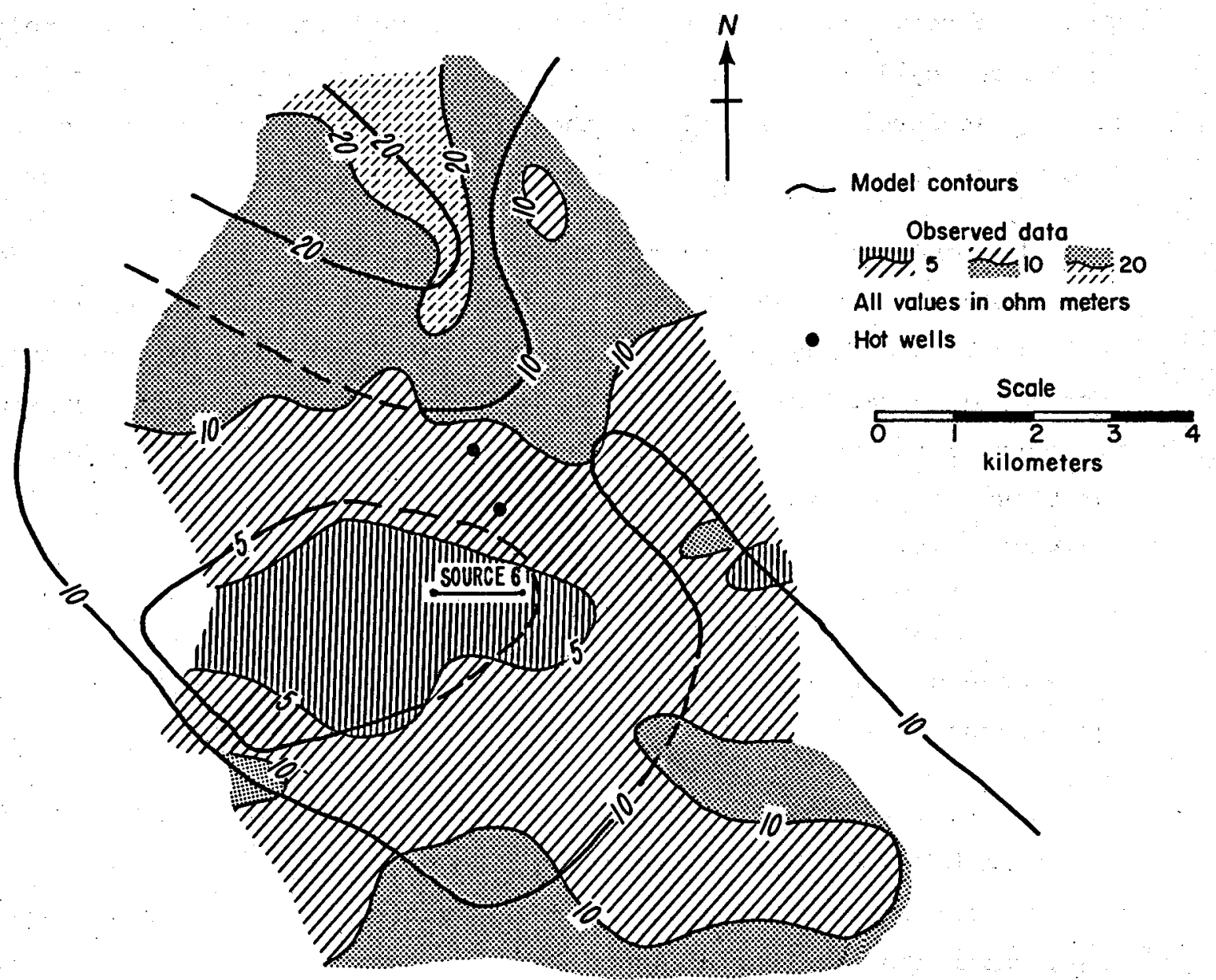

XBL $7810-6533$

Fig. 33. Source 6 observed data vs. model 62D calculated data. 


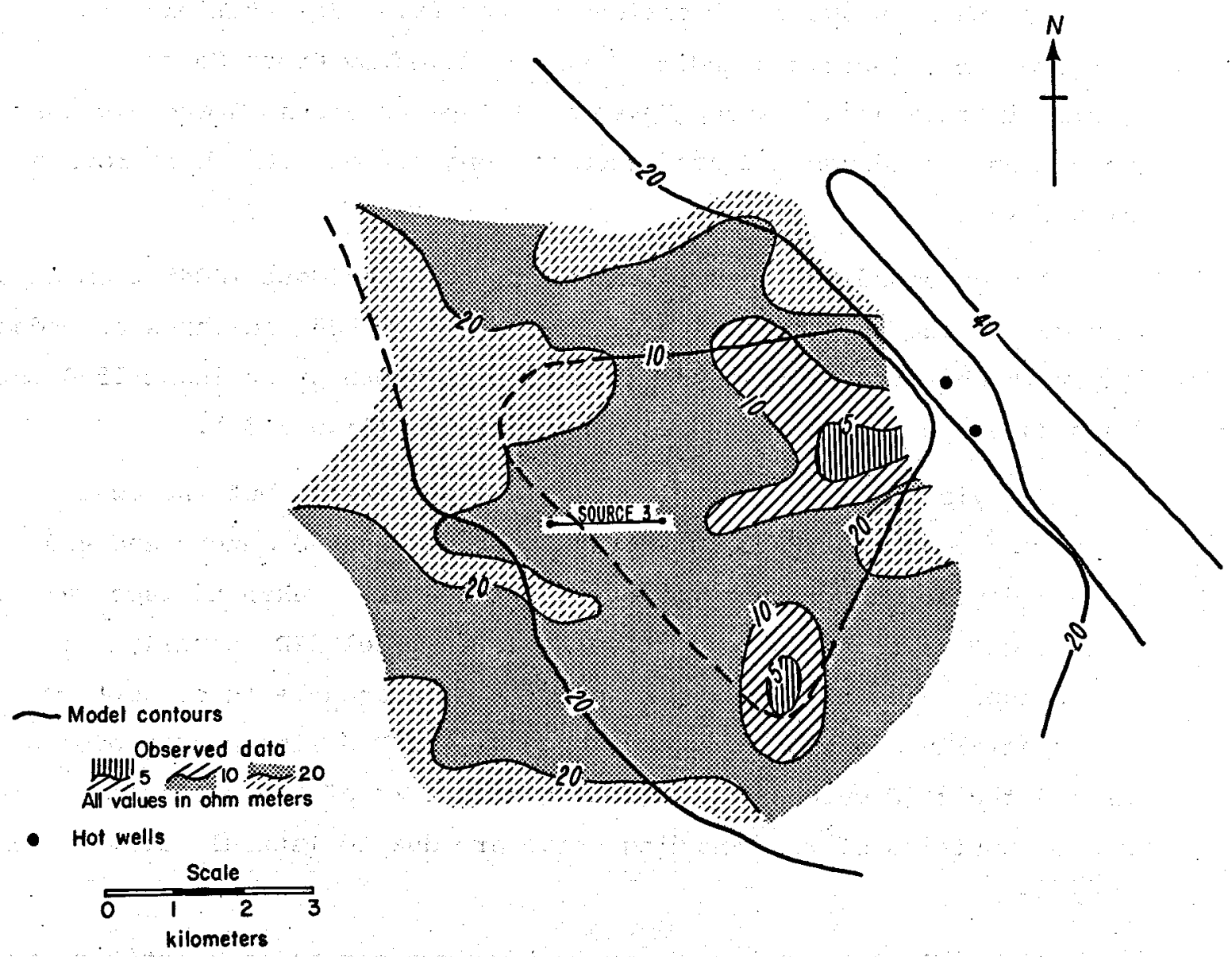

XBL 7810-6532

Flg. 34. Source 3 observed data vs model 32D calculated data. 
Direct Current and Electromagnetic Soundings

Figure 23 shows the locations of the five EM stations and the two dc electric sounding lines occupied by Group Seven (1972) in this area. Group Seven made layered-earth interpretations from these soundings and used them in conjunction with their roving dipole work.

The dc sounding lines extend east (DC3) and west (DC4) from bipole source 6. The interpretation of the data from DC4 indicates a conductive layer (5 ohm-meters) from the surface to a depth of at least 1500 meters. This agrees with our roving dipole model 62D (Figure 31).

DC3 yielded a more complicated interpretation, but the most important feature is a 3 ohm-meter layer between 40 meters and 430 meters depth, underlain by more resistant rock. Taken at face value, this suggests that the conductive layer in model 62D actually thins as it approaches the Hills. However, the layered-earth assumption is especially questionable here, because the DC3 line passes over a mapped fault (Figure 23), suggesting that some of the distortions and discontinuities of the sounding curve are due to lateral resistivity changes.

Similarly, the EM soundings require two-dimensional interpretation in the complex geology of the Klamath Hills. Group Seven's one-dimensional inversions indicated very low surface resistivities extending to a few hundred meters depth, underlain by more resistive rock. These interpretations should be regarded with caution.

\section{Synthesis and Geological Interpretation}

In the Lost River-Spring Lake Valley, we postulate one or more concealed northeast-trending faults crossing the valley northwest of Hosley. The southeast side of this structure is upthrown, resulting in a buried basement ridge trending between the Klamath Hills and Stukel Mountain beneath Hosley (Figure 23). 
The roving dipole, gravity, and AMT data sets are all consistent with this interpretation. In particular, the AMT data suggest a fault running roughly from olene Gap to Spring Lake. This may connect with the mapped north-trending fault between Spring Lake and the Hot Wells (Figure 27).

The gravity data indicate only 100 to 300 meters of alluvium overlying the inferred fault. Thus it is not surprising that the fault is detected at the lowest frequencies of the AMT survey. It is surprising, however, that the conductive zone appears at very high frequencies with skin depths of tens of meters. This may mean that the fault has displaced all but the most recent valley sediments.

The inferred fault trends perpendicular to the regional geologic strike, and should intersect several northwest-trending faults in its path. Obvious intersection points are olene Gap and off the northwestern tip of stukel Mountain. Geothermal activity may be enhanced at fault intersections. For example, Flgure 23 shows that two mapped faults intersect near the Hot Wells.

The relationship of the inferred "Olene Gap fault" to regional tectonics is unclear. It may be a transform between sets of northwest-trending normal faults, However, the regular alignment of volcanic centers spaced 20 to $30 \mathrm{~km}$ along the trend of the lineament may be indicative of a major fracture zone pre-dating and now obscured by the northeast-trending normal faults.

On the southwest side of the Klamath Hills, the most important feature is the conductive zone near the Hot Wells. This may be the result of fluid ascending along the fault zone and spreading out into sediments underlying Lower klamath Lake. The northwest-southeast extent of the zone is uncertain, but it seems to be truncated a few kllometers north of source 6 . 
The $50 \mathrm{ohm}$-meter dike-like feature in the roving dipole models may represent an impermeable fault zone or a basaltic dike. Impermeable faults are not uncomon in the Klamath Basin; mylonitization and silification seem to cause this phenomenon. On the other hand, some fault zones are highly fractured and permeable (Leonard and Harris, 1974). Thus it is reasonable to interpret linear resistivity anomalies whether conductive or resistive, as faults.

Geothermal Targets

We have presented evidence for two targets in the Klamath Hills area: the Hot Wells area and the inferred olene Gap fault zone.

The Hot Wells area is an established geothermal resource, but the reservoir area is sharply truncated by faults to the east, and appears to be quite limited in areal extent. For example, the 5,800 foot hole drilled by Natomas (Figure 23) was essentially isothermal. According to our geophysical interpretation, it appears that they drilled into the impermeable zone of model $6 \mathrm{~A}$, completely missing the zones of hydrothermal circulation. We recomend that future drilling be done on the southwest side of the fault. More detailed electrical resistivity work, such as dipole-dipole or EM soundings, is needed to determine reservoir extent.

Work is also needed in the Lost River-Spring Lake Valley, particularly around the inferred fault zone. At the northwestern tip of stukel Mountain, there are several warm wells ranging in temperature up to $42^{\circ} \mathrm{C}$ (Samel, 1976). However, the wells along the segment of the inferred fault zone between stukel Mountain and spring Lake do not, for the most part, exceed $20^{\circ} \mathrm{C}$. This may mean that at the tip of stukel Mountain, the extra permeability afforded by two intersecting faults has enhanced hydrothermal circulation. This area also exhibits the lowest AMT apparent resistivities (Station 16, Figure 26). However, the specific electrical conductivity of the well waters here is only about one-tenth of the values measured in the Hot Wells (Sammel, 1976); both measurements were made at a water temperature of $25^{\circ} \mathrm{C}$. Thus it comes as somewhat of a surprise that the estimated formation resistivities at a few hundred depths are approximately the same in both areas. 
Archie's Law is useful to consider here: $\rho_{r}=\rho_{f} \phi^{-n}$, where $\rho_{r}$ is the resistivity of the rock with its fluid, $\rho_{f}$ is the resistivity of the fluid and $\phi$ is the porosity; $n$ is about 2 for most rocks. We know that $\rho_{f}$ near the station 16 is roughly 10 times $\rho_{f}$ near the Hot Wells, even assuming that the fluid is the same temperature in both areas. This means that the rock at station 16 (at the tip of stukel Mountain) must be about 3 times more porous or that the fluid must be substantially hotter or more concentrated at a few hundred meters depth for the apparent resistivity there to be nearly equal to that in the vicinity of the Hot Wells.

Efforts should be made to investigate this inferred fault zone and determine the temperature gradient. Detailed gravity, dipoledipole resistivity, and self-potential surveys would be useful in understanding the structure here. In addition, the area appears to be far enough away from Upper Klamath Lake so that shallow temperature gradient drilling might provide meaningful information. pumping tests should be performed in existing wells to estimate the permeabilities in these rock units, and to establish any relationship between warm wells in the conductive zone and those elsewhere along the inferred fault.

Another interesting structure is the north-trending fault between Spring Lake and the Hot Wells. There are a few warm wells in the Klamath tills along this fault (samel, 1976). This fault may play an important role in the groundwater or hydrothermal circulation.

\section{EVALUATION OF GEOPHYSICAL METHODS}

In this study, we have examined and Interpreted gravity, magnetic, roving dipole resistivity, electromagnetic, direct current resistivity AMT and MT data sets. A brief assessment of each method as a geothermal prospecting tool in the Klamath Basin follows: 
1. Gravity and Magnetics: These methods seem suited for resolving structure, particularly concealed structures or those obscured by recent tectonics. They are useful for tracing faults and for helping to determine alluvium/sediment thickness in valleys.

2. Roving Dipole Resistivity: This can be a useful reconnaissance tool, but when used without other resistivity methods it is often difficult to interpret. Unless the inhomogeneity comes to surface, the anomaly may not be obvious and modeling becomes necessary for interpretation (Dey and Morrison, 1977). Computer modeling is expensive because of the large amount of interpreter's time required for all but the simplest conditions. In the area studied roving dipole revealed low apparent resistivity anomalies around the Klamath Falls "steamer zone" and the Klamath Hills Hot Wells. We caution against averaging apparent resistivity values from multiple transmitters

3. DC and EM Resistivity Soundings: From our limited examination of scanty data we can only conclude that one-dimensional interpretations are inadequate and misleading in this area. At least two-dimensional interpretations are needed, and this would require a greater station density than shown in the Klamath data.

4. AMT and MT: These methods offex perhaps more promise, but more headaches in interpretation, than the other techniques discussed. A major advantage of MT is that it often allows crustal modeling to depths of tens of kilometers. However, owing to local surface inhomogeneities and three-dimensional deep structure, it is rarely possible to satisfy both TE and TM data sets by means of a two-dimensional model. Scalar AMT, as performed by the U.S. Geological Survey, or scalar MT surveys, normally have limited interpretational possibilities. However, in the Lost RiverSpring Lake Valley, the scalar AMT data seem to reveal concealed structures.

5. Passive Seismic: One short microearthquake survey gave no useful information, and the value of the various passive seismic techniques cannot be assessed. 
Among the common geophysical exploration techniques, dipoledipole resistivity, self-potential and temperature gradient drilling were not used in the areas of this report. Dipole-dipole resistivity has been used extensively in other areas near Klamath Falls, and an assessment of that work will be discussed in a subsequent report. In general, if one were to use roving dipole as a reconnaissance tool, it would be wise to conduct several lines of dipole-dipole resistivity for control.

Recently, self-potential has been recognized as a rapid, low-cost and often informative technique for geothermal prospecting (Corwin and Hoover, 1979). Geothermally generated electric potentials due to electrokinetic and/or thermoelectric effects may produce anomalies of 50 to $200 \mathrm{mv}$. Self-potential surveys are recommended for use in future exploration as they may very well indicate regions of enhanced fluid flow along faults.

Shallow drilling for temperature gradient and heat flow measurements is one of the principal methods in geothermal exploration, yet has not been applied, to our knowledge, in the study areas. Cold water influx from the lake will mask thermal anomalies at shallow depth around the lake, and so a shallow drilling program should be mindful of this problem.

\section{CONCLUSIONS}

The Swan Lake Valley and Klamath Hills areas are small parts of the Klamath Basin geothermal system. Both lie outside the known resource being exploited near the city of klamath Falls.

Swan Lake Valley and the adjacent Meadow Lake Valley, are grabens with interior drainage and no proven resource potential. The southern end of the valleys lie along a northeast-trending gravity and aeromagnetic lineament (the Klamath Falls lineament). The importance of intersecting northeast and northwest-trending faults on the localization of fractured rock and hot water is speculative. However, we notice a good correlation between these interseations and hot water within explored parts of the basin. 
A northeast-trending aeromagnetic anomaly occurs over Swan Lake valiey, and this may be due to a dike-swarm within bedrock.

Aside from the speculation on the importance of northeast-trending structures, the most encouraging geophysical evidence for a geothermal system in the Swan Lake-Meadow Lake area comes from electrical resistivity data, particularly results of an MT survey. Three low resistivity zones are indicated:

(a) A 3 ohm-m zone occurs $40 \mathrm{~m}$ below the surface of Swan Lake Valley, adjacent to a fault marked by the Swan Lake rim and an associated steep gravity gradient.

(b) A laterally continuous (3) 6 to 8 ohm m layer underlies Swan Lake Valley at a depth of $1 \mathrm{~km}$. This could be an aquifer above the resistive bedrock.

(c) A 3 to 7 ohm-m vertical zone exists beneath Meadow Lake Valley.

The Klamath Hills and Stukel Mountain are northwest-trending highlands flanked by normal faults and surrounded by valleys filled with Quaternary alluvium and lacustrine sediments. Warm water has been found in wells west of the Klamath Hills and warm springs occur at the northwestern tip of Stukel Mountain and at olene Gap. All three occurrences align with another northeast-trending lineament in the gravity and aeromagnetic data. This lineament, called the olene Gap lineament, is also marked by an AMT resistivity anomaly between Olene Gap and the Klamath Hills. A concealed fault, downthrown side to the north, is the assumed cause for both the geophysical and geothermal anomalies. More intensive exploration of this zone is recommended.

A detailed interpretation of roving dipole resistivity data over Lower Klamath Lake suggests that a shallow warm water zone, up to one $\mathrm{km}$ thick, could border the west side of the klamath Hills. This low resistivity zone extends four $\mathrm{km}$ into the valley from the range-bounding fault. 
The existence of a high temperature reservoir remains a matter for speculation at this time. There is little evidence to support or refute the existence of an anomalous heat source such as a shallow magmatic source. We favor the concept of deep circulation along fault zones in a thinned continental crust as the heating mechanism, similar to systems in northern Nevada (Hose and Taylor, 1974). However, the Klamath Basin geothermal system appears to contain a larger volume of water than most Northern Nevada systems.

This is a progress report on an ongoing project. We have not finished studying the geophysical data in our hands, and more data should be forthcoming. We plan to continue our interpretations, expanding into other areas of the Klamath Basin as data become available. 
REFERENCES

Corwin, R.F. and Hoover, D.B., 1979, The self-potential method in geothermal exploration: Geophysics, v.44, no.2, pp. 226-245.

Dey, A., 1976, Computer program RESIS2D.

Dey, A. and Morrison, H.F., 1977, An analysis of the bipole-dipole resistivity method for geothermal exploration: Lawrence Berkeley Laboratory Report, LBL-6332.

Geonomics, Inc., 1977, A telluric-magnetotelluric survey of the Swan Lake Valley area, Oregon: Geonomics Incorporated, Berkeley, California.

Grant, F.S., and West, G.F., 1965, Interpretation theory in applied geophysics: McGraw Hill Book Company, New York, New York, p. 290 .

Group Seven Incorporated, 1972, Electrical resistivity surveys at Klamath Falls and Honey Lake: Group Seven Incorporated, Golden, Colorado.

Hohmann, G.W., and Ting, S.C., 1978, Three-dimensional magnetotelluric modeling: Earth Science Laboratory, University of Utah Research Institute, Salt Lake City, Utah.

Hose, R.K., and Taylor, B.E., 1974, Geothermal systems of northern Nevada: U:S. Geological Survey Open File Report 74-271.

Jupp, D.L.B., 1976, Computer program SM2D.

Leonard, A.R., and Harris, A.B., 1974, Groundwater in selected areas in the Klamath Basin, Oregon: Oregon State Engineer Groundwater Report No. 21.

Madden, T.R., 1970, Computer program EMCDC.

Natomas Company, 1978, i) Memorandum, February 26; 1976; ii) Map; iii) Well logs; iv) Seismicity report on the Klamath Hills prospect, Klamath County, Oregon: Microgeophysics Corporation, Golden, Colorado, 1976; v) Klamath Hills geothermal prospect, Klamath County, Oregon: Thermal Power Company, San Francisco, California; vi) Temperature gradient logging in the Klamath Hills area, Klamath County, Oregon: A.B. Esmilla Geothermal Surveys, Los Angeles, California, 1975; Natomas Company, San Francisco, California.

Newcomb, R.C., 1958, Yonna formation of the Klamath River basin, oregon: Northwest-Science, v.32, no.2, pp. 41-48. 
Peterson, N.V., and McIntyre; J.R., 1970, The reconnaissance geology and mineral resources of eastern Klamath County and western Lake County, Oregon: Oregon Department of Geology and Mineral Industries Bulletin 66 .

Sammel, E.A., 1976, Hydrologic reconnaissance of the geothermal area near Klamath Falls, Oregon: U.S. Geological Survey Open File Report WRI 76-127.

Senterfit, R.M., and Bedinger, G.M., 1976, Audio-magnetotelluric data log and station location map for the klamath Falls known geothermal resource area, Oregon: U.S. Geological Survey Open File Report 76-320.

Stanley, W.D., Buehl, J.E., Bostick, F.X., and Smith, H,W., 1977, Geothermal significance of magnetotelluric sounding in the eastern Snake River Plain-Yellowstone region: Journal of Geographic Resources, v.82, no.2, PP, 2501-2514.

Tang, R.W.Y., 1974, Geothermal exploration by telluric currents in the Klamath Falls Area, Oregon: M.S, thesis, Oregon State University, 86 p.

U.S. Geological Survey, 1972, Aeromagnetic map of the Klamath Falls and part of the Crescent $1^{\circ}$ by $2^{\circ}$ Quadrangle, Oregon; Open File Map 72-392.

U.S. Geological Survey, 1973, Aeromagnetic map of the Medford Sheet, Oregon: Open file report.

Van Deusen, J.E., III, 1978, Mapping geothermal anomalies in the Klamath Falls, Oregon region using gravity and magnetic data: M.S. thesis, University of Oregon, Department of Geology. 


\section{APPENDIX}

\section{KLAMATE BASIN GEOTHERMALI RESOURCE BIBLIOGRPAHY.}

Arnold, D., 1977, Energy crisis: Opportunity for savings at Presbyterian Intercommunity Hospital: Geo-Heat Utilization Center Quarterly Bulletin, v.2, no.4, pp. 1-3.

Berg, J.W., Jr., and Baker, C.D., 1963, Oregon earthquates, 1841 through 1958: Seismological Society of America Bulletin, v.53, no.1. pp. 95-108.

Blackwell, D.D., and Chapman, D.S., 1977, Interpretation of geothermal gradient and heat flow data for basin and range geothermal systems: Geothermal Resources Council, May 9, 1977, pp. 19-20.

Blank, H.R., 1966, General features of the Bouguer gravity field in southwest oregon: U.S. Geological Survey Professional Paper 550-C, pp. 113-119.

Blank, H.R., 1966, Aeromagnetic and gravity surveys of the Crater Lake Region, Oregon: In H.M. Dole (Ed.), Andesite Conference Guidebook, pp. 42-52.

Bodvarsson, G., 1966, Energy and power of geothermal resources: Oregon Dept. of Geol. and Min. Indust., v.28, no.7, pp. 117-124.

Bodvarsson, G., Couch, R.W., MacFarlane, W.T., Tang, R.W., and Whitsett, R.M., 1974, Telluric exploration for geothermal anomalies in Oregon: The Ore Bin, v.36, no.6, pp. 93-107.

Bowen, R.G., 1968, Geochemical sampling data, Klamath and Lake Counties, Oregon: Oregon Dept. of Geol. and Min. Indust., Open File Report, unpublished.

Bowen, R.G., 1972, Geothermal overviews of the western United States: California Geothermal Resources Council, pp. 138-146.

Bowen, R.G., 1975, Geothermal energy: Oregon Dept. Geol. and Mineral Indust. Misc. Paper 18, pp. 43-50.

Bowen, R.G., 1975b, Geothermal gradient data: Oregon Dept. of Geol. and Mineral Indust. Open File Report 0-75-3, 133 pp.

Bowen, R.G., Blackwell, H. D., and Hull, D.A., 1975, Geothermal studies and exploration in Oregon: Oregon Dept. of Geol. and Mineral Indust., Open File Report 0-75-7, 65 pp. 
Bowen, R.G., and Peterson, N.V., 1970, Thermal springs and wells in Oregon: Oregon Dept. Geol. and Mineral Indust. Misc. Paper 14.

Cantwel1, T., Nelson, P., Webb, J., and Orange, A.S., 1965, Further deep resistivity measurements in the Pacific Northwest: Jour. Geoph.Res., v.70, pp. 4068-4072.

Couch, R.W., and Lowell, R.P., 1971, Earthquakes and seismic energy release in Oregon: The ore Bin, v.33, no.4, pp.61-84.

Culver, G., 1975, A case for the down hole exchanger: Geo-Heat Utilization Center Quarterly Bulletin, v.1, no.2.

Culver, G., 1976, DHE investigations: Geo-Heat Utilization Quarterly Bulletin, v.2, no.2, pp. 1-2.

Culver, G., 1976b, Presbyterian Intercommunity Hospital goes geothermal: Geo-Heat Utilization Center Quarterly Bulletin, v.1, no.3.

Culver, G.G., 1977, Well drilling for < $250^{\circ} \mathrm{F}$ water: Geo-Heat Utilization Center Quarterly Bulletin, v.3, no.1, pp. 8-10.

Culver, G.G., Lund, J.W., and Svanevik, L.S., 1974, Klamath Falls hot water well study: Oregon Institute of Technology, Klamath Falls, Oregon (UCRL-13614), $61 \mathrm{pp}$.

Dey, A. and Morrison, H.F., 1977, An analysis of the bipole-dipole resistivity method for geothermal exploration: Lawrence Berkeley Laboratory Report, LBL-6332.

Dicken; S.N., 1950. Oregon geography: Edwards Bros., Ann Arbor, Michigan, 1st ed., 104 Pp., Pp. 61-67.

Dole, H.M., 1967, Geology is for everyone-fifteenth biennial report of the state geologist, 1964-1966: Oregon Dept. Geol. and Mineral Indust. Bull. $59,27 \mathrm{pp}$.

Fournier, R.O., 1973, An empirical Na-K-Ca geothermometer for natural waters: Geochim. Cosmochim. Acta, v.37, pp. 1255-1275.

Frank, F.J., and Harris, A.B., 1969, Water resources appraisal of Crater Lake National Park, Oregon: U.S. Geological Survey Open File Report, $26 \mathrm{pp}$.

Geomonics, 1977, A telluric-magnetotelluric survey of the Swan Lake Valley Area, Oregon: Geonomics Inc., Berkeley, California, Project No. 164, prepared for Creslenn Oil Co., Oklahoma City, Oklahoma.

Geothermal Energy, 1974, Heat mine spurs big Oregon push (Klamath Falls): Geothermal Energy, v.2, no.10, pp. 32-33. 
Groh, E.A., 1966, Geothermal energy potential in oregon: The Ore Bin, v.28, no.7, pp. 125-135.

Group Seven, 1972, Electrical resistivity surveys at Klamath Falls and Honey Lake: Group Seven, Inc., Golden Colo., Final report prepared for Gulf Mineral Resources Co., Denver, Colo., 153 p.

Hubbard, L.L., 1970, Water budget of Upper Klamath Lake, Southwestern Oregon: U.S. Geol. Survey Hydrologic Investigations Atlas HA-35l.

Hull, D.A., Blackwell, D.D., Bowen, R.G., Peterson, N.V., and Black, G.L., 1977, Geothermal gradient data: Oregon Dept. Geol. and Mineral Indust., Open File Report 0-77-2, 135 pp.

Hull, D.A., and Newton, V.C., Jr., 1976, Geothermal activity in 1975: The ore Bin, v.38, no.1, pp. 10-17.

Hunt Energy, Corporation, 1978, Well permits issued: Hunt Energy Corporation (Well permits issue to Hunt Energy Corporation to June 1978, map with three pages).

Illian, J.R., 1970, Interim report on the ground water in the Klamath Basin, Oregon: Oregon State Engineer, $110 \mathrm{pp}$.

Johnson, D.W., 1918, Block faulting in the Klamath Lakes Region, Oregon: Jour.Geol., v.26, pp. 229-236.

Johnson, L., Jr., 1969, Obsidian hydration rate for the Klamath Basin of California and Oregon: Science, v.165, no.3900, pp. 1354-1346, illus.

Karr, D.J., 1977, Geothermal energy and water resources: Oregon State University Water Resources Research Institute, Corvallis, Oregon, $121 \mathrm{pp}$.

Karr, D.J., and Laskin, S., 1977, The geothermally heated greenhouse: Geo-Heat Utilization Center Quarterly Bulletin, V.2, no.3, pp. 1-3.

Kibby, H.V., Donaldson, J.R., and Bond, C.E., 1968, Temperature and current observations in Crater Lake, Oregon: Limnol. Oceanog., v.13, no.2, pp. 363-366.

Klamath Ranger District, 1971, Klamath Ranger district map, Winema National Forest, Oregon: Willamette Meridian, U.S. Dept. Agricult. Forest Service.

Lawrence, R.D., 1974. Northern termination of the basin and range province in Oregon: Oreg. Acad. Sci., Proceedings, v.10; pp.68-69. 
Lawrence, R.D., 1976, strike-slip faulting terminates the basin and range province in Oregon: Geol. Soc. Amer. Bull., v.87, no.6, pp. 846-850.

Leonard, A.R., and Harris, A.B., 1974, Ground water in selected areas in the Klamath Basin, Oregon: Oregon State Engineer, Ground Water Report No. 21, 104 pp.

Lienau, P.J., 1975, OIT adds a new building to its geothermal heating system: Geo-Heat Utilization Center Quarterly Bulletin, v.1, no.2, pp. $1-2$.

Lienau, P., 1976, Report. on center activities: Geo-Heat Utilization Center quarterly Bulletin, v.2, no.1, pp. 8-9.

Lienau, P.J., 1976b, A comparison of downhole vs. surface heat exchangers for geothermal heating of schools: Geo-Heat Utilization Center Quarterly Bulletin, pp. 5-6.

Lienau, P.J., 1976c, Geo-heated swiming pool: Geo-Heat Utilization Center Quarterly Bulletin, v.l, no.4, pp. 2-3.

Lienau, P.J., 1977, Geothermal heating system, Oregon Institute of Technology: Geo-Heat Utilization Center Quarterly Bulletin, v.2, no.4, pp. 6-8.

Lienau, P.J., n.d., Agribusiness geothermal energy utilization potential of Klamath and snake River basins, Oregon: Manuscrlpt, pp. 1-10.

Ilenau, P.J., and Lund, J.W., n.d., Utilization and economics of geothermal space heating in Klamath Falls, Oregon: Manuscript, pp. 1-10.

Lienau, P.J., Lund, J.W., and Culver, G.G., 1976, Klamath County geo-heating districts: Oregon Institute of Technology, Klamath Falls, Oregon.

Lund, J.W., 1975. Geology and energy utilization of the Klamath Falls known geothermal resource area: Proceedings, 13th Annual Symposium on Engineering Geology and Soils Engineering, Moscow, Idaho.

Lund, J.W., 1975b, New development in the Klamath Falls KGRA: Geo-Heat Utilization Center Newsletter, v.1, no.1, p. 3.

Lund, J.W., 1976, Geothermal de-icing of a highway pavement: Geo-Heat Utilization Center Quarterly Bulletin, v.l, no.3, pp. 7-9.

Lund, J.W., 1976, Geothermal de-icing of pavements: Geo-Heat Utilization Center Quarterly Bulletin, v.1, no.4, p. 7 . 
Iund, J.W., 1977, Direct use of geothermal water for apartment heating: Geo-Heat Utilization Center Quarterly Bulletin, v.2, no.3, pp. 7-8.

Lund, J.W., 1977b. Geothermal heating of Kingswood Apartments, Klamath Falls: Geo-Heat Utilization Center Quarterly Bulletin, v.3, no.1, pp. 4-6.

Lund, J.W., 1978. Big springs: Geo-Heat Utilization Center Quarterly Bulletin, v.3, no.3, pp. 7-13.

Lund, J.W., n.d., Geology and energy utilization of the Klamath Falls known geothermal resource area: Manuscript, pp. 187-200.

Lund, J.W., Culver, G., and Lienau, P.J.; n.d.; Groundwater characteristics and corrosion problems associated with the use of geothermal water in Klamath Falls, Oregon: Manuscript, 17 p.

Lund, J.W., Culver, G.G., and Svanevik, L.S., 1974, Utilization of geothermal energy in Klamath Falls: Proceedings, Conference on Geothermal Energy for Industrial, Agricultural and Commercial Uses, Oregon Institute of Technology, Klamath Falls, Oregon, pp. 146-178.

Lund, J.W., Culver, G.G., and Svanevik, L.S., 1976, Utilization of intermediate-temperature geothermal water in Klamath Falls, Oregon: Proceedings of the Second United Nations Symposium on the Development and Use of Geothermal Resources, San Francisco, California, 20 May 1975, v.3, pp. 2147-2154.

Lund, J.W., and Lienau, P.J. 1976, Mini-heating district for Klamath Falls churches: Geo-Heat Utilization Center quarterly Bulletin, v.1, no.4.

Lyons, T., 1976, Geothermal energy in California--status report. Appendix B, Administrative requirements for development of geothermal resources: Jet Propulsion Laboratory, Pasadena, California, JPL-5040-25 (Rev. A), pp. B.1-B.11.

MacLeod, N.S., Walker, G.W., and McKee, E.H., 1975, Geothermal significance of eastward increase in age of Upper Cenozoic rhyolitic domes in southeastern Oregon: U.S. Geol. Survey Open File Report 75-348, 22 p. 
Mariner, R.H., Presser, T.S., Rapp, J.B., and Willey, L.M., 1975, The minor and trace elements, gas and isotope composition of principal hot springs of Nevada and Oregon: U.S. Geol. Survey Open File Report 75-348, 27 p.

Mariner, R.H., Rapp, J.R., Willey, L.M., and Presser, T.S., 1974, The chemical composition and estimated minimum reservoir temperatures of selected hot springs in Oregon: USGS Open File Report, $27 \mathrm{p}$.

Maynard, L.C., 1974, Geology of Mount McLoughiin: University of Oregon, Unpublished thesis, $139 \mathrm{p}$.

Merewether, E.A., 1953, Geology of the lower Sprague River area, Klamath County, Oregon: Master's thesis, Oregon State University, 62 p.

Meyers, J.D., and Newcomb, R.C. 1952, Geology and ground water resources of the Swan Lake-Yonna Valley area, Klamath County, Oregon: U.S. Geol. Survey Open File Report, 151 p.

Nathenson, M., and Muffler, L.J.P., 1975, Geothermal resources in hydrothermal convenction systems and conduction-dominated areas: In D.E. White and D.I. Williams (Eds.), Assessment of geothermal resources of the United States, 1975, U.S. Geol. Survey Circular 726, pp. 104-121.

Natomas, 1978, 1) Memorandum, 26 February 1976; 2) Map; 3) Well logs; 4) Seismicity report on the Klamath Hills prospect, Klamath County, Oregon: Microgeophysics Corp., Golden, Colo., 22 Dec. 1975;

5) Klamath Hills geothermal rpospect, Klamath County, Oregon: Thermal Power Company, San Francisco, Calif., 7 June 1976;

6) Temperature gradient logging in the Klamath Hills area, Klamath County, Oregon: A.B. Esmilla Geothermal Surveys, Los Angeles, Calif., October 1975: Natomas Company, San Francisco, Calif.

Newcomb, J.M., 1976, Malntenance problems and solutions in geothermal well plumbing: Geo-Heat Utilization Center Quarterly Bulletin, v.I, no.4, pp. 4-6.

Newcomb, R.C., 1958, Yonna formation of the Klamath River Basin, Oregon: Northwest Science, v.32, no.2, pp. 41-48.

Newcomb, R.C., and Hart, D.H., 1958, Preliminary report on the groundwater resources of the Klamath River Basin, Oregon: U.S. Geol. Survey, Open File Report, 248 p.

Newton, V.C., 1971, Folsom Basin disposal site, Klamath County, Oregon: Oregon Dept. Geol. and Mineral Indust., $10 \mathrm{p}$. 
Newton, V.C., Jr., and Peterson, N.V., 1973, Geologic criteria for siting nuclear power plants in Oregon: Oregon Dept. Geol. and Mineral Industr., $65 \mathrm{p}$.

Oregon State Water Resources Board, 1971, Klamath Basin: Oregon State Water Resources Baord, Salem, Oregon; 288 p.

Pacific Southwest Inter-Agency Committee, Sacramento, Water Management Technical Subcomittee, 1973, River Mile Index--Klamath River, Pacific Slope Basin, California-Oregon, 56 p.

Peterson, D.L., and Meyer, R.F., 1976, Principal facts for a gravity survey of Summer Lake known geothermal resource area, Oregon: U.S. Geol. Survey OFR-76-702A, $5 \mathrm{pp}$.

Peterson, N.V., 1959, Lake County's new continuous geyser: The Ore Bin, v. 21, no.9, pp. 83-88.

Peterson; N.V., and Groh, E.A., 1967, Geothermal potential of the Klamath Falls area, Oregon--a preliminary study: The Ore Bin, v.29, no.11, pp. 209-231.

Peterson, N.V., and McIntyre, J.R., 1970, The reconnaissance geology and mineral resources of eastern Klamath County and western Lake County, Oregon: Oregon Dept. of Geol. and Mineral Indust. Bulletin $66,70 \mathrm{pp}$.

Phillips, K.N., Van Denburgh, A.S., 1968, Hydrology of Crater, East, and Davis Lakes, Oregon: U.S. Geol. Survey Water Supply Paper 1859-E, Pp. 1-60.

Purvine, W.D., 1974, Utilization of thermal energy at Oregon Institute of Technology, Klamath Falls, Oregon: Proceedings, International Conference on Geothermal Energy, Oregon Institute of Technology, Klamath Falls, Oregon.

Renner, J.L., 1976, Selected geothermal resources data--hydrothermal convection systems in the states of Alaska, Arizona, California, Colorado, Hawaii, Idaho, Montana, Nevada, New Mexico, Oregon, Utah, Washington, and Wyoming: U.S. Geol, Survey CD-76-001, $357 \mathrm{pp}$.

Renner, J.L., White, D.E., and Williams, D.L., 1975, Hydrothermal convenction systems. In D.E. White and D.L. Williams (Eds.), Assessment of geothermal resources in the United States-1975, U.S. Geol. Survey Circular 726, pp. 5-57.

Rineheart, J.S., 1970, Geysering action in a drilled well, Crump, Lake County, Oregon: J.Geophys. Res., v.75, no.32, pp. 6714-6716, illus. 
Sacarto, D.M., 1976, state policies for geothermal development; National Science Foundation, Washington, D.C., 24 pp.

Sammel, D.A., 1976, Hydrologic reconnaissance of the geothermal area near Klamath Falls, Oregon: U.S. Geol. Survey Open File Report WRI 76-127, 129 pp.

Sass, J.H., and Sammel, E.A., 1976, Heat-flow data and their relation to observed geothermal phenomena near Klamath Falls, Oregon:

J. Geophys. Research, v.81, no.26, pp. 4863-4868.

Scintrex Mineral Surveys, Inc., 1972, Aeromagnetic map of the Klamath Falls and Cresent Sheets, Oregon: U.S. Geol. Survey Open File Report.

Senterfit, R.M., and Bedinger, G.M., 1976, Audio-magnetotelluric data log and station location map for Klamath Falls known geothermal resource area, Oregon:. U.S. Geol. Survey Open File Report 76-320, pp. 1-6.

Smith, J.L., Isselhardt, C.F., and Matlick, J.S., 1977, Summary of 1976 geothermal drilling--Western United States: Geothermal Energy Magazine, v.5, no.5, pp. 8-9, 11-13, 15-17.

Storey, D.M., 1974, Geothermal drilling in Klamath Falls, Oregon: Proceedings, International Conference on Geothermal Energy, Oregon Institute of Technology, Klamath Falls, Oregon, 8 October 1974, $10 \mathrm{pp}$.

Tang, R.W.Y., 1974, Geothermal exploration by telluric currents in the Klamath Falls area, Oregon: Master's thesis, Oregon State University, Corvallis, Oregon, $86 \mathrm{pp}$.

Thiruvathukal, J.v., Berg, J.W., Jr., and Heinrichs, D.C., 1970, Regional gravity of Oregon: Geol, Soc. Amer. Bull., v.81, pp. 725738.

Trauger, F.D., 1950, Basic groundwater data in Lake County, Oregon: U.S. Geol. Survey Prof. Paper 492, p. 271.

U.S. Geological Survey, 1972, Surface water supply of the United States, 1966-1970. Part II. Pacific Slope basins in California. Volume 2. Basins from Arroyo Grande to oregon state line except central valley: U.S. Geological Survey Water Supply PaPer 2129, pp. 526-659.

U.S. Geological Survey, 1977, Water resources investigations in Oregon, 1977: U.S. Geological Survey Water Data Report OR-77-1, 607 pp. 
van Deusen, J.E., 1978, Mapping geothermal anomalies in the Klamath Falls, Oregon region using gravity and aeromagentic data: MS thesis, University of Oregon, Eugene, pp.

van Meter, C., 1940, Heating with hot water wells: Driller, v.14, no.4, pp. 4-7.

van Orstrand, C.E., 1938, Temperatures in the lava beds of east-central and south-central oregon: Amer. J. Sci., v.35, no.205, pp. 22-46.

von Hake, C.A., 1976, Earthquake history of Oregon: Earthquake Information Bulletin, v.8, no.3, pp. 30-33, illus.

Walker, G.W., 1963, Reconnaissance geologic map of the eastern half of the Klamath Falls (AMS) quadrangle, Lake and Klamath Counties, Oregon: U.S. Geol. Survey Mineral Investigations Field Studies Map, MF-260.

Walker, G.W., 1970, Cenozoic ash flow tuffs of Oregon: The Ore Bin, v.32, no.6, pp. 97-115.

Walker, G.W., 1973, Preliminary geologic and tectonic maps of Oregon east of the 12lst meridian: U.S. Geol. Survey Misc. Field Studies Map MF-495.

Walker, G.W., 1974. Some implications of late Cenozoic volcanism to geothermal potential in the high lava plains of south-central Oregon: The Ore Bin, v.36, pp. 109-119.

Walker, G.W., Delrymple, G.B., and Lanphere, M.A. 1974. Index to potassium argon ages of Cenozoic volcanic rocks of Oregon:

U.S. Geol. Survey, Misc. Field Studies Map MF-569.

Walker, G.W., and King, P.B., 1969, Geologic map of oregon: U.S. Geol. Suevey Misc. Geol. Map I-595.

Walker, G.W., MacLeod, N.S., and McKee, E.H., 1974, Transgressive age of late Cenozoic silicic volcanic rocks across southeastern oregon-impoications for geothermal potential: Geol. Soc. Amer. Abs. with Programs, v.6, no.3, p. 272.

Wells, F.G., and Peck, D.L., 1961, Geologic map of Oregon west of the 12lst meridian: U.S. Geol. Survey Misc. Geol. Inv. Map 1-325.

Wells, R.E., 1975, Geology of the Drake Peak rhyolite complex and the surrounding area, Lake County, Oregon: Master's thesis.

Weyerhauser, n.d., Material received from Geothermex on geothermal exploration work for Wyerrhauser Co. and Pacific Power and Light Co. 
Wimer, R.D., Lamori, P.N., and Grant, A.D., 1977, Potential environmental issues related to geothermal power generation in oregon: The Ore Bin, v.39, no.5, pp. 73-91.

Youngquist, W., 1977, Pacific northwest geothermal--1976 review, 1977 outlook: Geothermal Energy Magazine, v.5, no.6, pp. 8-13, 15-17.

Zoback, M.L., and Thompson, G.A., 1976, Evidence of left-lateral slip on basin and range fault: Geol. Soc. Amer., Abstr. Programs, v.8, no.6, p. 1182 . 